\author{
Universidade de São Paulo \\ Interunidades em Ciências e Engenharia de Materiais
}

\title{
Confecção e Caracterização Óptica e Estrutural de Lentes Plásticas Obtidas pelo Processo de Injeção
}

Aparecido Rodrigues da Silva

Dissertação apresentada ao programa de pós-graduação da Área Interunidades em Ciência e Engenharia de Materiais da Universidade de São Paulo para obtenção do titulo de Mestre em Ciência e Engenharia de Materiais.

Orientador: Prof. Dr. Euclydes Marega Junior USP/FSC/SBI

São Carlos

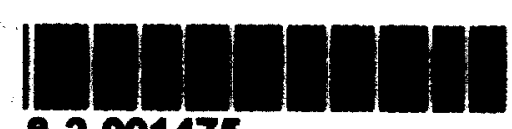

2002 


\section{Silva, Aparecido Rodrigues da}

"Confecção e Caracterização Óptica e Estrutural de Lentes Plásticas Obtidas pelo Processo de Injeção"/ Aparecido Rodrigues da Silva - São Carlos, 2002

Dissertação (Mestrado) - Instituto de Física de São Carlos da Universidade de São Paulo, 2002 páginas: 80

Área: Ciência e Engenharia de Materiais

Orientador: Prof. Dr. Euclydes Marega Júnior

1. Lentes Plásticas; 2. Processo de Injeção; 3. Caracterização Optica.

I. Título 


\section{UNIVERSIDADE DE SÃO PAULO}

\section{Ciência e Engenharia de Materiais}

Caixa Postal 369 -CEP 13560-970 - São Carlos-SP - Brasil

Tel: (0xx16) 2739589/ Fax: (0xx16) 2739777

MEMBROS DA COMISSÃO JULGADORA DA DISSERTAÇÃO DE MESTRADO DE APARECIDO RODRIGUES DA SILVA, APRESENTADA À ÁREA INTERUNIDADES CIÊNCIA E ENGENHARIA DE MATERIAIS, UNIVERSIDADE DE SÃO PAULO, EM 19-12-2002.

\section{COMISSÃO JULGADORA:}

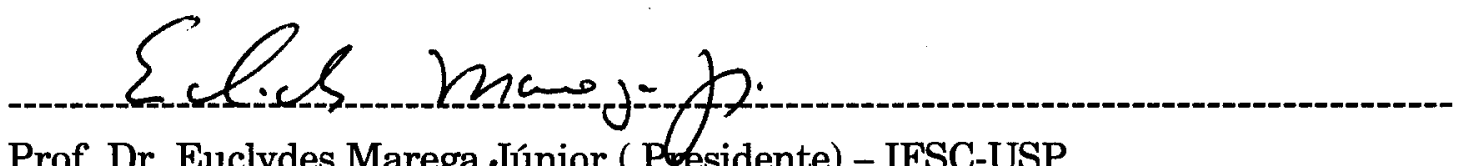

Prof. Dr. Euclydes Marega Júnior ( Płesidente) - IFSC-USP

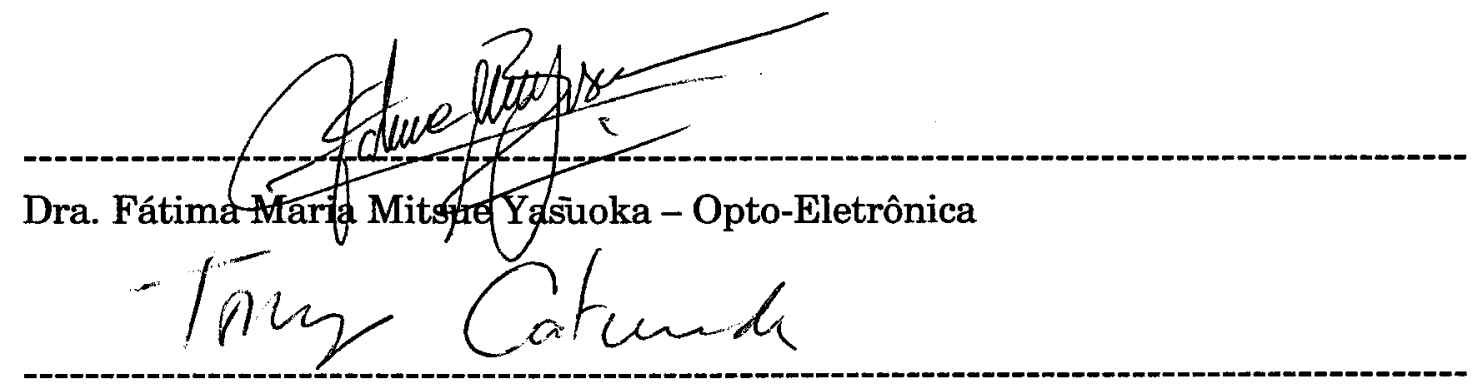

Prof. Dr. Tomaz Catunda - IFSC-USP 
À Andréa, minha esposa, pelo apoio e carinho e à Thaissa e Thainá, nossas filhas, por serem a fonte de inspiração que nos permite vencer os obstáculos. 


\section{ÍNDICE}

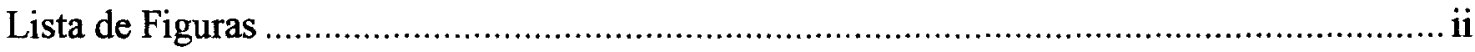

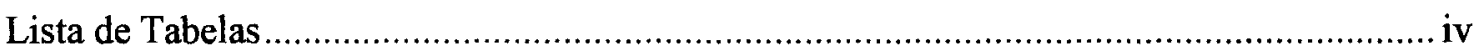

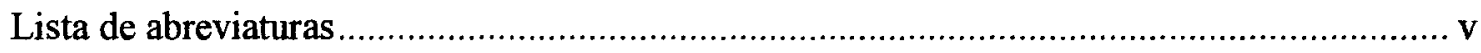

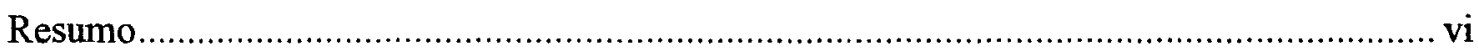

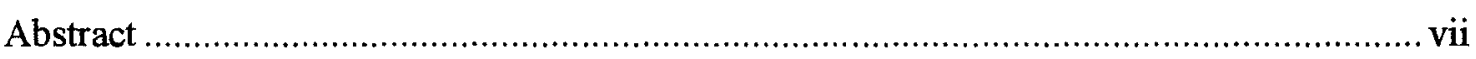

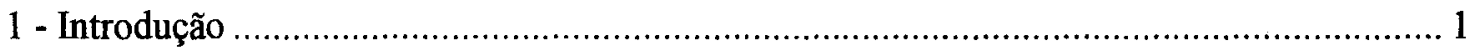

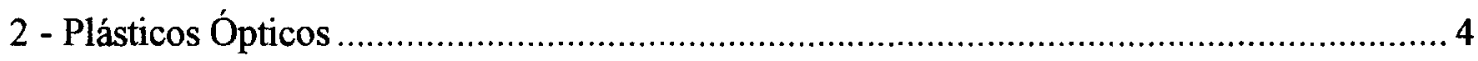

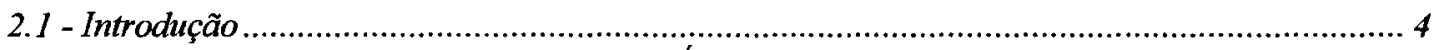

2.2 - Vantagens e Desvantagens dos Plásticos Ópticos................................................................... 4

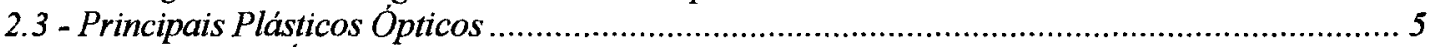

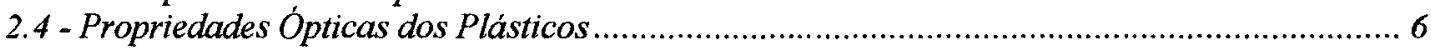

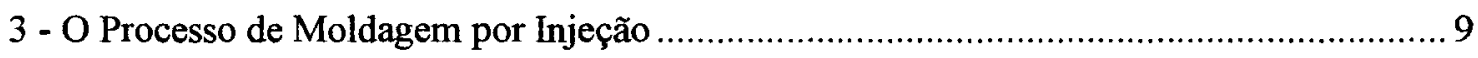

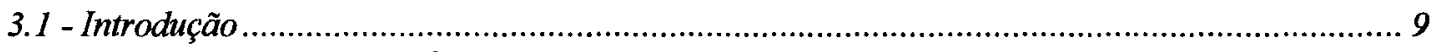

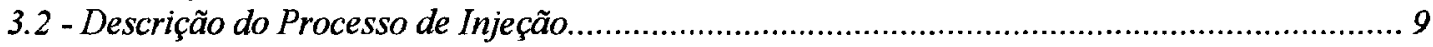

3.3 - As Variáveis do Processo de Injeção de Termoplásticos...................................................... 12

3.4 - Reologia do Plástico Fundido ....................................................................................

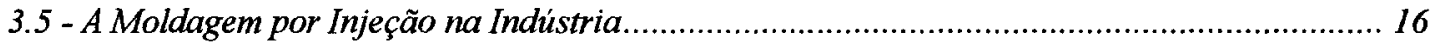

3.6 - Moldagem por Injeção-Compressão............................................................................ 16

3.7 - Dados Técnicos e Notas sobre a Injeção de Plásticos ....................................................... 18

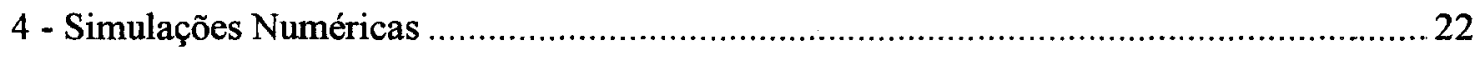

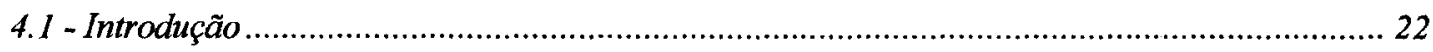

4.2 - Modelo Computacional da Lente e Canais do Molde ........................................................... 22

4.3 - Resultados Obtidos na Simulação da Injeção........................................................................ 23

5 - Projeto e Construção do Molde para Injeção das Lentes ............................................... 27

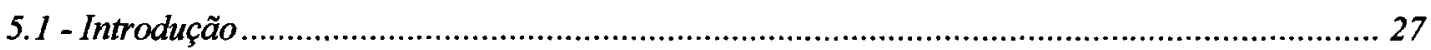

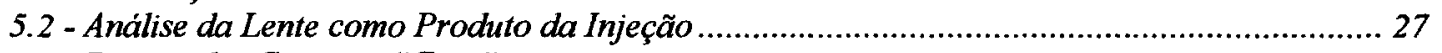

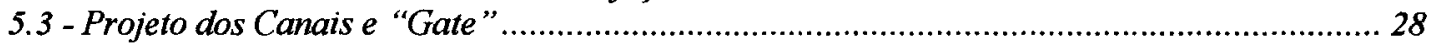

5.4 - Projeto do Sistema de Refrigeração ................................................................................. 30

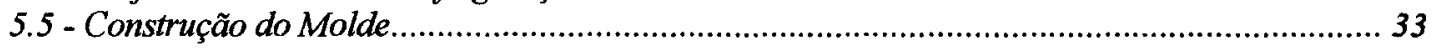

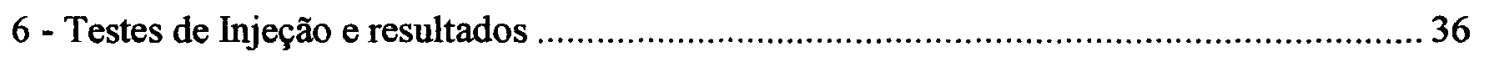

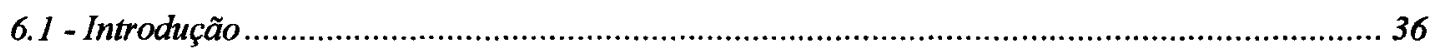

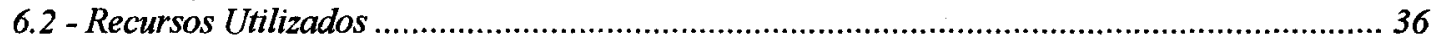

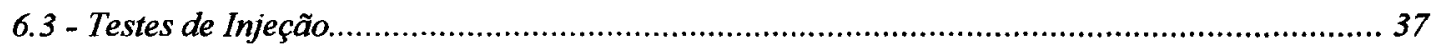

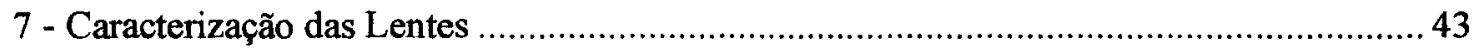

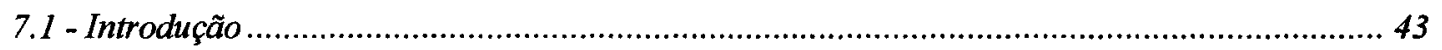

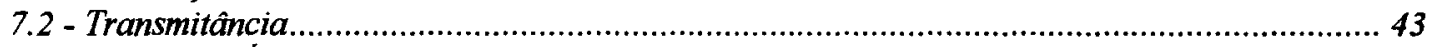

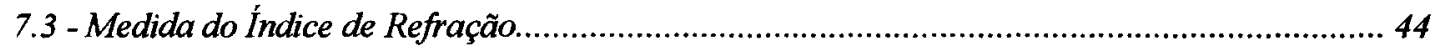

7.4 - Birrefrigência e Tratamento Térmico para Alivio de Tensões................................................ 45

7.5 - Medida de Função de Transferência de Modulação - FTM................................................. 47

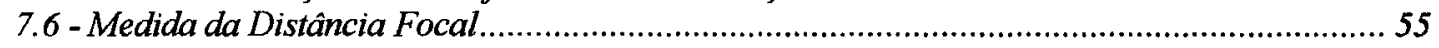

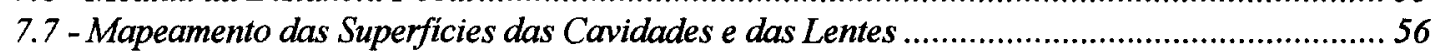

7.8 - Medidas de Planicidade dos Perfis Circulares da Lente .........................................................6 65

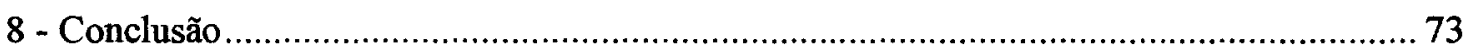

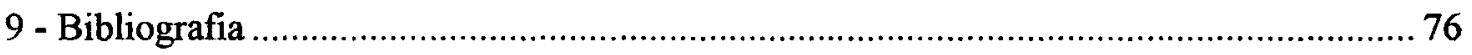

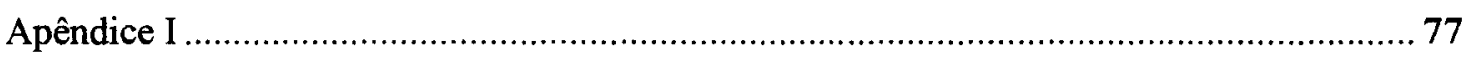

O Processo de Fabricação de Lentes por Termo-Moldagem ...................................................... 77

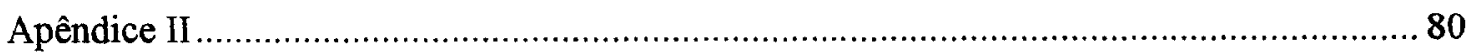

Comparação entre Processos de Fabricação de Lentes............................................................. 80 


\section{LISTA DE FIGURAS}

Figura 3.1 - Diagrama esquemático da moldagem por injeção ..................................... 10

Figura 3.2 - Unidade de injeção do tipo rosca-sem-fim (Sors et al,) .............................. 11

Figura 3.3 - Reômetro para análise do fluxo de materiais............................................ 13

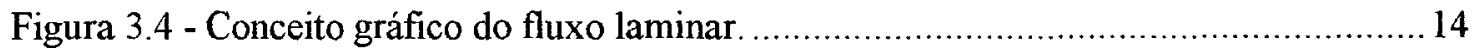

Figura 4.1 - Modelo tridimensional da lente e canais do molde .......................................23

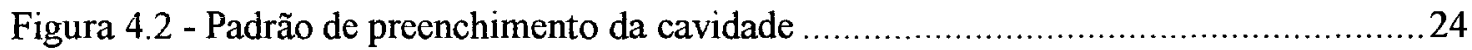

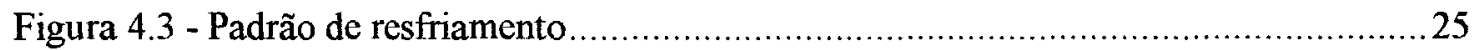

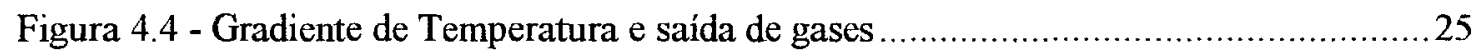

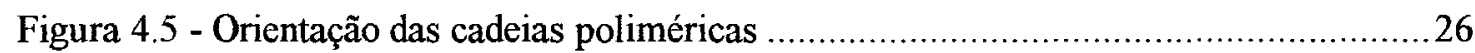

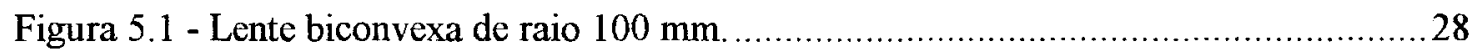

Figura 5.2 - Configuração do sistema de alimentação da cavidade .................................29

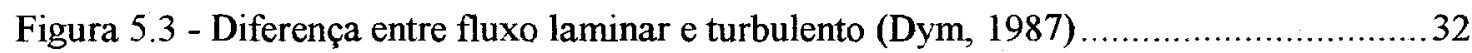

Figura 5.4 - Molde para injetar lentes acrílicas desmontado ........................................ 34

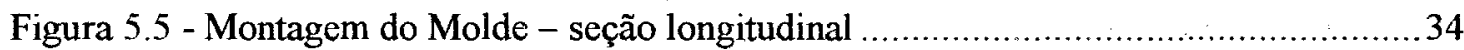

Figura 5.6 - Montagem do Molde - seção tranversal ........................................................ 35

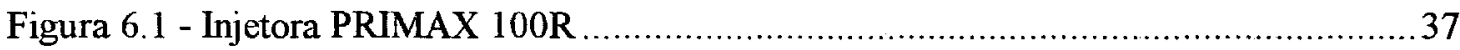

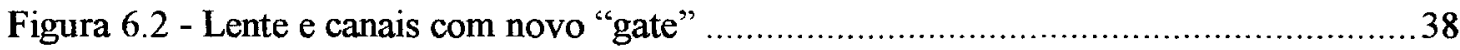

Figura 6.3 - Molde na injetora durante a fase de extração. .............................................. 42

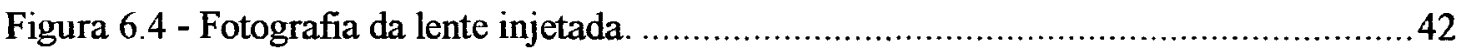

Figura 7.1 - Representação gráfica da transmitância das lentes injetadas.............................44

Figura 7.2 - Avaliação de birrefrigência da lente de acrílico ...........................................46

Figura 7.3 - Birrefrigência das lentes injetadas - (A) policarbonato, (B) poliestireno. ..........46

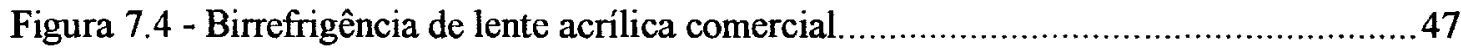

Figura 7.5 - Padrão de linhas e formação da imagem em testes ópticos (Smith, 1966) ........ 49

Figura 7.6 - Contraste da imagem como função da freqüência espacial (Smith, 1966) .........50

Figura 7.7 - Análise gráfica da FTM das amostras de acrílico 01-DH-LE...........................52

Figura 7.8 - Análise gráfica da FTM das amostras de poliestireno. ................................53

Figura 7.9 - Análise gráfica da FTM das amostras de acrílico 01-DH-ECL .......................53

Figura 7.10 - Análise gráfica da FTM das amostras de acrílico 01-DH-ECL-P...................54

Figura 7.11 - FTM - lentes Z, lentes comerciais, lente do IFSC e lente padrão...................55

Figura 7.12 - Definição dos eixos transversal e longitudinal da lente e cavidades................57

Figura 7.13 - Diferença entre perfil com $\mathrm{R}=106 \mathrm{~mm}$ e o perfil longitudinal do inserto superior. 
Figura 7.14 - Diferença entre perfil com $R=112,6 \mathrm{~mm}$ e o perfil longitudinal do inserto inferior.

Figura 7.15 - Diferença entre o perfil da face superior da cavidade e o perfil longitudinal da face superior da lente $Z$. 60

Figura 7.16 - Diferença entre perfis longitudinal e transversal da face superior da lente $Z \ldots 60$

Figura 7.17 - Diferença entre perfil com $R=113,5 \mathrm{~mm}$ e o perfil longitudinal da face superior da lente $Z$

Figura 7.18 - Diferença entre o perfil da face inferior da cavidade e o perfil longitudinal da face inferior da lente $Z$.

Figura 7.19 - Diferença entre perfis longitudinal e transversal da face inferior da lente $Z$....62

Figura 7.20 - Diferença entre perfil com $\mathrm{R}=118,1 \mathrm{~mm}$ e o perfil longitudinal da face inferior da lente $Z$.

Figura 7.21 - Diferença entre perfil com $R=115,1 \mathrm{~mm}$ e o perfil longitudinal da face superior da lente de PC.

Figura 7.22 - Diferença entre perfil com $R=116,6 \mathrm{~mm}$ e o perfil longitudinal da face inferior da lente de PC.

Figura 7.23 - Diferença entre perfil com $R=113,6 \mathrm{~mm}$ e o perfil longitudinal da face superior da lente de PS.

Figura 7.24 - Diferença entre perfil com $R=118 \mathrm{~mm}$ e o perfil longitudinal da face inferior da lente de PS.

Figura 7.25 - Esquema do dispositivo de medida de planicidade. 66

Figura 7.26 - Definição da medida de planicidade. 66

Figura 7.27 - Definição do centro de referência (LS) e do ângulo. 67

Figura 7.28 - Amostra do resultado apresentado para medidas de planicidade. 68

Figura 7.29 - Gráfico da planicidade associada à posição para face inferior e superior da lente. 69

Figura 7.30 - Representação do perfil da face inferior para $R=15 \mathrm{~mm}$. 69

Figura 7.31 - Representação do perfil da face inferior para $R=20,1 \mathrm{~mm}$. 70

Figura 7.32 - Representação do perfil da face inferior para $R=24,1 \mathrm{~mm}$. 71

Figura 7.33- Representação do perfil da face superior para $R=15,2 \mathrm{~mm} \ldots \ldots \ldots \ldots \ldots \ldots \ldots \ldots . .71$

Figura 7.34 - Representação do perfil da face superior para $\mathrm{R}=20,2 \mathrm{~mm}$. ........................ 72

Figura 7.35 - Representação do perfil da face superior para $R=24,3 \mathrm{~mm}$. ......................73

Figura A1 - Fotografia da montagem do molde para termo-moldagem na prensa. .............77

Figura A2 - Desenho do molde para termo-moldagem.............................................. 78

Figura A3 - Análise de birrefrigência das lentes termo-moldadas...................................79 


\section{LISTA DE TABELAS}

Tabela 2.1 - Propriedades físicas dos principais plásticos ópticos (U.S, 1983)...................... 7

Tabela 3.1 - Propriedades físicas do acrílico e poliestireno ................................................ 19

Tabela 3.2 - Parâmetros para processamento do acrílico e do poliestireno ........................... 20

Tabela 3.3 - Parâmetros para injeção de acrílico e poliestireno .......................................... 21

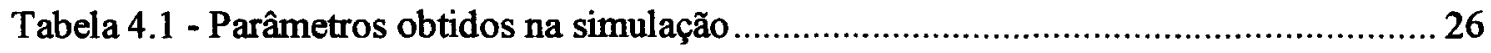

Tabela 6.1 - Características técnicas do acrílico Acrigel@ (Metacril).................................... 38

Tabela 6.2 - Parâmetros de processo utilizados nos principais testes de injeção................... 40

Tabela 7.1 - Características de lentes de procedência variada .............................................. 55

Tabela Al - Valores envolvidos nos vários processos de fabricação de lentes. ................... 80 


\section{LISTA DE ABREVIATURAS}

CDCC - Centro de Divulgação Científica e Cultural.

IFSC - Instituto de Física de São Carlos

FTF - Função de Transferência de Fase.

FTM - Função de Transferência de Modulação.

FTO - Função de Transferência Óptica.

PC - Policarbonato.

PMMA - Polimetacrilato de metila (acrílico).

PS - Poliestireno. 


\section{RESUMO}

O propósito desse trabalho foi o de produzir lentes biconvexas pelo processo de injeção para serem utilizadas no ensino de óptica geométrica e de ciências nos níveis fundamental e médio. A importância de tal trabalho se justifica na carência de material experimental didático produzido no mercado nacional. Para atingir os objetivos propostos, foi necessário estudar o processo de injeção de termoplásticos e adequá-lo à produção de um componente óptico. No desenvolvimento do trabalho, foi projetado e confeccionado um molde para injeção das lentes, segundo especificações técnicas e apoiado em resultados obtidos através de simulações numéricas. Após a realização de testes de injeção, seguiu-se a caracterização das lentes obtidas através de parâmetros ópticos: transparência, birrefrigência, índice de refração, distância focal, raio de curvatura e FTM. 


\begin{abstract}
The purpose of this work was the development and production of acrylic biconvex lens by injection process to be used in optical and science teaching at elementary and high schools. The importance of such work is based in the deficiency of experimental didactic material made in Brazil. In order to achieve the intended objective it was necessary to study the thermoplastic injection process and adapt it to the fabrication of an optical element. During the development of the work a mold was designed and constructed in according to technical specifications and based on results of numerical simulations. After the injection tests the lens were characterized by theirs optical parameters: transparency, birefrigence, refraction index, focal distance, curvature radius and MFT.
\end{abstract}




\section{1 - INTRODUÇÃo}

Os altos custos relacionados com o desenvolvimento e produção de materiais didáticos aliados a sua baixa demanda no mercado resultam em uma grande carência desse tipo de produto em nosso país. Agravando esse quadro, as escolas não têm dado a devida importância à utilização de materiais de apoio no ensino de ciências. Esse comportamento por parte das indústrias e das escolas tem tornado nosso pais quase que totalmente dependente de materiais didáticos importados. Torna-se evidente a necessidade do desenvolvimento de meios para produzir materiais didáticos de baixo custo.

Particularmente, para o ensino de óptica, seja ele no nível médio ou superior, existe um grande interesse na obtenção de equipamentos que possam ser adquiridos a um custo inferior aos dos equipamentos feitos em vidro.

Equipamentos ópticos para o ensino são feitos tradicionalmente de vidro polido, os quais até o momento continuam sendo os que apresentam melhores propriedades ópticas. A utilização do plástico como material alternativo para a confecção de elementos ópticos tem ocorrido principalmente em casos em que não se exige grande precisão. $O$ baixo custo de produção e algumas qualidades, como por exemplo, maior resistência a impactos e menor peso, têm motivado as indústrias a utilizarem cada vez mais o plástico como matéria-prima na confecção de elementos ópticos.

Com isso em mente, pretendeu-se nesse trabalho desenvolver e produzir lentes injetadas para utilização em aulas experimentais de óptica nos níveis fundamental e médio de ensino, pois, conforme se observa, a maior parte do material destinado a essas aulas é importada e de alto custo. Outro fator que merece consideração e a metalização da superficie do acrílico que tem se mostrado muito eficiente, o que poderia também possibilitar a elaboração de espelhos esféricos e ou asféricos.

A utilização do plástico na fabricação de lentes tem ocorrido desde a primeira metade do século 20 como uma forma alternativa para a produção de lentes para aplicações onde a precisão não é crítica. Deve-se salientar porém que, diferentemente do vidro que apresenta grande variedade de tipos, na utilização de plásticos ópticos os tipos utilizados se reduzem a poucos sendo que o polimetacrilato de metila (acrílico) é o que apresenta melhores resultados.

O início do desenvolvimento de lentes plásticas no Centro de Divulgação Científica e Cultural da USP (CDCC) deu-se por volta de 1992. A primeira tentativa foi a moldagem de chapas de acrílico previamente aquecidas no formato de uma lente, e ou, superficies esféricas. Inicialmente, o processo apresentou problemas com o surgimento de bolhas nas lentes e tentou-se confeccioná-las com poliéster fundido, entornado em moldes de vidro; 
contudo, sem resultado satisfatório. Voltando ao processo de prensagem, desenvolve-se, então, um processo de prensagem a vácuo, aprimorado em trabalhos realizados por Cruz, 1997 e Silva, 1998.

0 método para fabricação de lentes pelo processo de termo-moldagem à vácuo apresenta bons resultados para a aplicação desejada. Porém, a fabricação dessas lentes apresenta baixa produtividade e custo relativamente alto. Uma descrição desse processo é apresentada no apêndice I e os custos no apêndice II.

A fabricação de lentes pelo processo de injeção apresenta a vantagem de altíssima produtividade. Em contrapartida, o processo exige um controle adequado das condições de umidade e pureza do material termoplástico empregado e dos ajustes da máquina injetora utilizada, além de moldes corretamente construídos.

No que se refere à construção do molde, atenção especial deve ser dada ao material a ser utilizado para a confecção das cavidades. Uma escolha incorreta do material pode tornar o acabamento das superficies inadequado ou reduzir a vida útil do molde.

No processo de injeção não é apenas a exatidão dimensional do molde ou uma correta distribuição de fluxo que interferem na qualidade do produto final. $\mathbf{O}$ controle da temperatura do molde durante os ciclos de injeção e resfriamento, bem como, a correta escolha dos parâmetros na máquina injetora podem interferir decisivamente na qualidade final das lentes. Isso exige atenção especial e deve ser considerado como objeto de estudo muito importante.

Neste trabalho foram produzidas lentes biconvexas com $50 \mathrm{~mm}$ de diâmetro e com raio de curvatura de $100 \mathrm{~mm}$. Como foi dito anteriormente, o objetivo foi produzir lentes plásticas que apresentassem características adequadas às necessidades do Ensino Médio e, em um segundo enfoque, que pudessem também ser utilizadas em equipamentos ópticos.

Dessa forma, o trabalho se desenvolveu da seguinte maneira:

O capítulo 2 inicia o trabalho com um estudo dos materiais plásticos que podem ser utilizados nesse tipo de aplicação.

No capítulo 3, aborda-se o processo de injeção com enfoque para as variáveis envolvidas, segue-se um estudo da reologia do plástico fundido para melhor compreensão do comportamento do plástico durante o preenchimento da cavidade. $O$ processo de injeçãocompressão que não pôde ser utilizado nesse trabalho foi descrito porque pode servir como referência para trabalhos futuros nessa área. Finalmente, são levantados alguns dados técnicos relacionados com o processo de injeção do acrílico e poliestireno na injeção de lentes.

No capitulo 4, são apresentados alguns resultados obtidos através de simulações numéricas do processo de injeção da lente. Esse tópico foi julgado importante devido à 
relativa complexidade da construção do molde que impossibilita ajustes rápidos em falhas decorrentes de erros no projeto. Com o auxílio dessas simulações pôde-se verificar se o projeto do molde era adequado e se havia a necessidade de correções.

No capítulo 5 , são apresentados detalhes do projeto e construção do molde com enfoque para o projeto dos canais de alimentação da cavidade e do sistema de refrigeração.

0 capítulo 6 apresenta a metodologia utilizada para a realização dos testes de injeção, os recursos que foram utilizados e os resultados preliminares das lentes obtidas.

No capitulo 7, são descritos os resultados de medidas realizadas com as lentes obtidas. Parâmetros ópticos como transparência, birrefrigência, FTM, distância focal e índice de refração foram analisados e seus resultados são apresentados. No capítulo 7 , são apresentados, também, os resultados obtidos através da análise morfológica da superfície da lente e das cavidades que foram realizadas com instrumentos de inspeção de superficies.

$O$ capítulo 8 traz as conclusões obtidas com esse trabalho. São apresentadas também sugestões para futuros trabalhos nessa área que podem melhorar a qualidade do produto final e reduzir os custos desse material de apoio à Educação. 


\section{2 - PLÁSTICOS ÓPTICOS}

\section{1 - Introdução}

Plásticos ópticos são materiais transparentes que podem ser moldados ou fundidos na forma desejada. Existem duas categorias nas quais plásticos ópticos podem ser encontrados: os termoplásticos, que podem ser refundidos várias vezes e nos quais ocorre uma pequena degradação a cada ciclo e os termofixos, que uma vez fundidos não podem mais ser derretidos sem a degradação completa. A forma básica na qual a maioria dos termoplásticos é encontrada é a forma de pó ou "pellets". Alguns materiais são fundidos na forma de blocos que posteriormente são usinados e polidos para aplicações especiais que requerem elementos muito grandes em pequeno volume.

Nesse capitulo, serão apresentadas as vantagens e desvantagens da utilização dos plásticos ópticos na produção de lentes. Serão apresentadas também as propriedades ópticas e algumas características adicionais dos principais plásticos ópticos que são consideradas relevantes para esse trabalho.

\section{2 - Vantagens e Desvantagens dos Plásticos Ópticos}

Vários são os fatores que influenciam na escolha de um determinado material para aplicação óptica. Entre muitos fatores podem ser citados o índice de refração, a resistência à abrasão, a estabilidade térmica e a facilidade de processamento. Tradicionalmente, o vidro tem sido o material mais utilizado na confecção de elementos ópticos de precisão.

O vidro apresenta características insuperáveis como alta resistência à abrasão, variedade de tipos com diferentes índices de refração e alta estabilidade térmica. Contudo, o processamento do vidro para a produção de lentes é difícil e dispendioso. Além dessa desvantagem, lentes confeccionadas em vidro são pesadas e apresentam pouca resistência a impactos diretos. Plásticos ópticos, por outro lado, apresentam várias vantagens em relação ao vidro:

Baixo custo: o processo de moldagem por injeção é ideal para a produção de grande quantidade de peças. Utilizando-se moldes com múltiplas cavidades, pode-se combinar os custos de fabricação e vida útil do molde a uma produção que torne o processo muito atraente do ponto de vista econômico, principalmente quando comparado aos custos de fabricação tradicional de lentes em vidro polido.

Montagem compacta de sistemas ópticos: o processo de injeção permite agregar em uma única peça furos, fendas, flanges, elementos de posicionamento e centralização e outros que permitem montagem de sistemas ópticos extremamente compactos. 
Confecção de lentes asféricas: praticamente todo equipamento de desbaste e polimento de lentes em vidro emprega mecanismos que utilizam movimentos mecânicos para contorno de superficies esféricas. É claro que a maneira mais tradicional de acabamento de insertos de moldes para lentes também se utiliza de movimentos semelhantes ao do polimento de lentes em vidro. Contudo, o complexo processo para produção de uma superficie asférica é necessário apenas uma vez por cavidade que posteriormente produzirá milhares de lentes asféricas.

Repetitibilidade: o processo de injeção pode apresentar uma alta repetitibilidade com uma tolerância para o diâmetro e espessura de $\pm 0,025 \mathrm{~mm}$ (U.S, 1983) para lentes com $25,4 \mathrm{~mm}$ de diâmetro. A variação na distância focal pode ser mantida em $0,1 \%$ para lentes de alta qualidade, sendo essa uma significante vantagem sobre o vidro.

Peso: para um dado volume, vidros ópticos pesam aproximadamente 2,3 a 4,9 vezes mais que o plástico (U.S, 1983). Isso se torna relevante principalmente quando grandes elementos ópticos são utilizados em um sistema.

Transmissão da luz: a transmitância do acrílico é maior que a maioria dos vidros ópticos ao longo do espectro visível. Outros plásticos ópticos têm uma transmitância típica de muitos vidros ópticos, que é levemente menor que a do acrílico. A transmitância de plásticos ópticos é melhor que a da maioria dos vidros no ultravioleta e nos comprimentos de onda próximos ao infravermelho. $\mathbf{O}$ final do espectro ultravioleta é normalmente restringido pela introdução de aditivos utilizados para proteger materiais sensiveis a esse tipo de radiação.

Entre as principais desvantagens dos plásticos na confecção de lentes estão a limitação na escolha do índice de refração que varia entre 1,45 e 1,60 e a temperatura de serviço reduzida que se situa no máximo de $116^{\circ} \mathrm{C}$ para o melhor deles (Cruz, 1997).

\section{3 - Principais Plásticos Ópticos}

Polimetacrilato de Metila (acrílico): $O$ acrílico é o mais importante e mais extensamente utilizado dos plásticos ópticos. Ele reúne características que o tornam extremamente interessante como material para fabricação de lentes. É o mais duro e estável mecanicamente entre os plásticos ópticos. A absorção no acrílico é menor que $0,5 \%$ por polegada apresentando, portanto, uma transparência maior que a maioria dos vidros ópticos. O material tem um índice de refração $\left(n_{D}\right)$ de 1,491. O acrílico é utilizado em mais de $80 \%$ das aplicações ópticas para lentes, sendo que sua utilização é geralmente evitada somente em componentes sujeito a altas temperaturas de serviço, aplicações que exigem resistência a solventes ou altos índices de refração (U.S., 1983). O acrilico exibe uma expansão linear de $2 \%$ após imersão em água, por 10 dias, a uma temperatura de $22.8{ }^{\circ} \mathrm{C}$. Essa pequena expansão pode ser ignorada na maioria das aplicações. 
Poliestireno: Os Poliestirenos fabricados antigamente tinham impurezas que reduziam a transmissão de luz no final da faixa azul do espectro, fazendo com que o material apresentasse uma coloração amarelada. Atualmente essa caracteristica só é evidente para seções extremamente espessas e as lentes feitas em poliestireno são geralmente quase tão claras quanto as lentes de acrilico. Apresentando um índice de refração $\left(n_{D}\right)$ de 1,59 , o poliestireno permite o projeto de lentes com seções mais finas e, portanto, com menores custos. Infelizmente o material não tem resistência à radiação UV e risca mais facilmente que o acrílico. Porém, possuindo um baixo valor do número de Abbe, juntamente com um alto índice de refração, o poliestireno pode ser usado como o "vidro flint", um excelente material complementar para sistemas com lentes de acrílico, permitindo projetos de sistemas para correções acromáticas.

NAS: $O$ acrílico e o poliestireno podem ser combinados em diferentes proporções resultando em copolímeros com índices de refração que variam de 1,53 a 1,57. Quando o copolimero apresenta $70 \%$ de poliestireno e $30 \%$ de acrílico tem-se o NAS que possui um índice de refração de 1,564 (U.S., 1983). O NAS apresenta as características de menor custo em relação ao acrílico e maior resistência ao risco que o poliestireno. Devido à mistura dos polímeros, o índice de refração do material é de dificil controle. O NAS tem sido usado como um terceiro material em sistemas corretores acromáticos.

Policarbonato: A alta resistência a impactos, aliada a uma faixa de temperatura de serviço extensa $\left(-137,2^{\circ} \mathrm{C} \mathrm{a} 115,6^{\circ} \mathrm{C}\right)$, tornam o policarbonato um material muito importante em aplicações em que a precisão óptica não é crítica, como em lentes para iluminação pública, janelas a prova de balas etc. Com um índice de refração de 1,586 e com baixo valor do número de Abbe, o policarbonato é opticamente similar ao poliestireno. Devido a sua alta ductilidade, ele não pode ser usinado facilmente, sendo a moldagem por injeção a alternativa mais viável, apesar de custosa, na fabricação de elementos ópticos de policarbonato.

CR-39 (Carbonato Diglicol de Alila): O CR-39 é o único termofixo utilizado em aplicações ópticas. $O$ material é normalmente entornado em moldes de vidro e então curado sob condições de temperatura altamente controladas. Possui excelente transmitância e resistência à abrasão, ao impacto e aos solventes. Sendo um termofixo, pode suportar temperaturas de serviço de até $100^{\circ} \mathrm{C}$ e operações curtas de até $149^{\circ} \mathrm{C}$ (U.S., 1983) sem degradação significante. $\mathrm{O}$ principal uso do CR-39 é em lentes oftálmicas. $\mathbf{O}$ alto percentual de contração limita sua utilização.

\section{4 - Propriedades Ópticas dos Plásticos}

Diferentes características físicas impõem aos plásticos ópticos, características ópticas distintas conforme pode ser visto na tabela 2.1. Essas características são descritas a seguir. 
Transmitância: A transmitância de um material é a razão entre a luz transmitida e a luz incidente. A transmitância é influenciada pela reflexão e pela absorção.

Perdas por reflexão: $\mathrm{O}$ acrílico com $3,17 \mathrm{~mm}$ de espessura apresenta $8 \%$ de perdas de transmitância, desse percentual mais de 7,5\% deve-se à reflexão (U.S,1983). Perdas por reflexão ocorrem em todos os materiais transparentes onde o ar é o meio adjacente. Materiais com maiores índices de refração têm maiores perdas por reflexão.

Absorcão: Características de absorção para materiais claros são dificeis de serem distinguidas dos efeitos de espalhamento interno da luz. "Haze", a característica que é normalmente relatada, é geralmente menor de $2 \%$ a $3 \%$. Excetuando-se as aplicações mais críticas, os efeitos de absorção podem ser geralmente ignorados.

Tabela 2.1 - Propriedades físicas dos principais plásticos ópticos (U.S, 1983).

\begin{tabular}{|l|l|c|c|c|c|}
\hline \multicolumn{2}{|c|}{ Propriedade } & Acrílico & Poliestireno & Policarbonato & NAS \\
\hline Índice de & $\left(N_{f}\right)(486,1 \mathrm{~nm})$ & 1,491 & 1,590 & 1,586 & 1,564 \\
Refração & $\left(N_{c}\right)(656,3 \mathrm{~nm})$ & 1,497 & 1,604 & 1,593 & 1,574 \\
& $\left(N_{d}\right)(589,3 \mathrm{~nm})$ & 1,489 & 1,584 & 1,576 & 1,558 \\
\hline $\mathrm{N}^{\circ}$ de Abbe & 57,2 & 30,8 & 34 & 35 \\
\hline dn/dt $x 10^{-3} /{ }^{\circ} \mathrm{C}$ & $-8,5$ & $-12,0$ & $-14,3$ & $-14,0$ \\
\hline Haze $(\%)$ & $<2$ & $<3$ & $<3$ & $<3$ \\
\hline Transmitância(\%)(esp.3,17mm) & 92 & $87-92$ & $85-91$ & 90 \\
\hline Angulo Crítico $\left(i_{c}\right)$ & $42,1^{\circ}$ & $39,0^{\circ}$ & $39,1^{\circ}$ & $39,8^{\circ}$ \\
\hline Temper. de serviço max. $\left({ }^{\circ} \mathrm{C}\right)$ & 79,4 & 79,4 & 115,6 & 79,4 \\
\hline Densidade $\left(\mathrm{g} / \mathrm{cm}^{3}\right)$ & 1,19 & 1,06 & 1,20 & 1,09 \\
\hline
\end{tabular}

Todos os plásticos ópticos degradam de alguma forma quando expostos a radiação ultravioleta (UV). O acrílico é o mais resistente à radiação UV. Após 20 anos de exposição ao ar livre, as perdas de transmitância do acrílico são da ordem de apenas $1 \%$ (U.S, 1983). $O$ poliestireno e o policarbonato degradam a uma taxa muito maior e em algumas aplicações necessitam de elementos que são agregados a sua formulação para protegê-los da ação da radiação UV.

$\mathrm{Na}$ região visível do espectro, todos os plásticos ópticos transmitem bem, apesar de alguns plásticos absorverem certos comprimentos de onda mais do que outros.

Os principais plásticos ópticos transmitem bem na região próxima ao infravermelho até aproximadamente $1,5 \mu \mathrm{m}$.

Índice de Refracão: Na escolha dos materiais a serem empregados no projeto de um sistema óptico, o índice de refração é um dos fatores mais importantes a serem considerados. $O$ índice de refração é listado em tabelas de propriedades físicas e relaciona o ângulo de 
incidência com o ângulo de refração de raios luminosos que atravessam a interface de separação entre um meio e outro. Os índices para vários plásticos são tabelados para diferentes comprimentos de onda e variam de cerca de 1,47 a 1,61 ou maior (U.S, 1983). Os índices de refração dos materiais plásticos variam com a temperatura, apesar desse fator não ser importante para a maioria das aplicações.

Número de Abbe: A variação do índice de refração para diferentes comprimentos de onda em um material óptico é chamada de dispersão. A dispersão faz com que um raio de luz divida-se em seus comprimentos de onda constituintes quando ele passa através do material. $\mathrm{O}$ número de Abbe é utilizado para exprimir a dispersão em um material e é expresso pela equação:

$$
V_{d}=\left(n_{d}-1\right) /\left(n_{f}-n_{c}\right)
$$

onde os índices $d, f$ e $c$ correspondem aos comprimentos de onda respectivos de $\lambda_{\mathrm{d}}=589,3$ $\mathrm{nm}$ (amarelo), $\lambda_{f}=486,1 \mathrm{~nm}$ (azul)e $\lambda_{\mathrm{c}}=656,3 \mathrm{~nm}$ (vermelho). Genericamente, vidros são classificados de acordo com o valor do número de Abbe em crown, para $v_{d}$ maior de $50 \mathrm{e}$ flint, para $v_{d}$ menor que 50 (Cruz, 1997).

$\mathrm{O}$ valor $\left(n_{f}-n_{c}\right)$ é dependente do índice de refração do material sendo que, quando esse aumenta, o valor do número de Abbe diminui.

Birrefrigência: Birrefrigência é a diferença entre o índice de refração de um material para a passagem da luz com o plano de polarização em um ângulo $\theta$ do índice de refração da luz passando em uma segunda direção com plano de polarização $\theta+90^{\circ}$. Essa condição ocorre devido à existência de tensões internas e é uma característica básica para muitos materiais ópticos.

Em partes plásticas, tensões internas são introduzidas durante a fabricação contudo, lentes plásticas têm sido confeccionadas com reduzida birrefrigência. Em aplicações muito críticas, a birrefrigência precisa ser analisada. No entanto, para a maioria das aplicações ópticas essa condição pode ser ignorada. 


\section{3 - O PROCESSO DE MOLDAGEM POR INJEÇÃO}

\section{1 - Introdução}

A moldagem por injeção consiste em prensar um material pré-aquecido na cavidade de um molde pela ação do aríete da máquina injetora. A máquina dispõe de um reservatório de material que pode ser alimentado contínua e automaticamente por equipamentos adequados. Ao final do processo, os produtos saem prontos para uso. $\mathrm{O}$ ciclo relativamente baixo de injeção das peças faz com que os custos diretos de produção pareçam muito pequenos numa primeira análise, porém, os custos envolvidos na aquisição dos equipamentos, moldes e matérias-primas são fatores que contribuem para o aumento significativo dos custos reais. Contudo, a moldagem por injeção ainda é um dos meios menos dispendiosos de produção de peças seriadas.

Para a compreensão dos fenômenos relacionados com a injeção, torna-se necessário, nesse capítulo, apresentar a sistemática envolvida no processo. Também serão apresentados alguns conceitos teóricos relacionados ao fluxo do material termoplástico fundido. Além disso, serão descritos alguns conceitos do tipo de injeção denominada injeção-compressão, uma breve explanação da metodologia de trabalho adotada pela indústria de materiais termoplásticos e dados técnicos relacionados à injeção de elementos em acrílico e poliestireno.

\section{2 - Descrição do Processo de Injeção}

As fases da moldagem por injeção em uma máquina do tipo rosca-sem-fim podem ser assim descritas:

1. O operador enche o tanque da máquina com material plástico granular e aciona a máquina;

2. O material admitido pelo alimentador é comprimido pela rotação de uma cavilha roscada que pré-aquece o material por atrito;

3. O material é forçado para a zona aquecida onde se funde totalmente;

4. $O$ dispositivo de trava da máquina prensa a metade móvel do molde contra a parte estacionária e o molde é fechado;

5. A cavilha roscada, funcionando como um ariete, injeta o material fundido através do bocal da máquina, através da bucha de entrada e do sistema de canais de distribuição do molde, na cavidade do molde, empurrando o ar à frente do material na cavidade; 
6. O material em contato com as paredes laterais do molde frio resfria-se e solidifica-se;

7. A máquina abre o molde e o produto é removido da cavidade presa à placa fixa da injetora;

8. O mecanismo ejetor da máquina aciona o extrator do molde que libera o produto acabado do molde.

A figura 3.1 ilustra de forma resumida as fases de admissão do material no canhão da máquina, injeção no interior do molde e extração da peça acabada. A máquina ilustrada é mais adequada para exemplificar o processo devido a sua simplicidade e foi muito utilizada no passado.
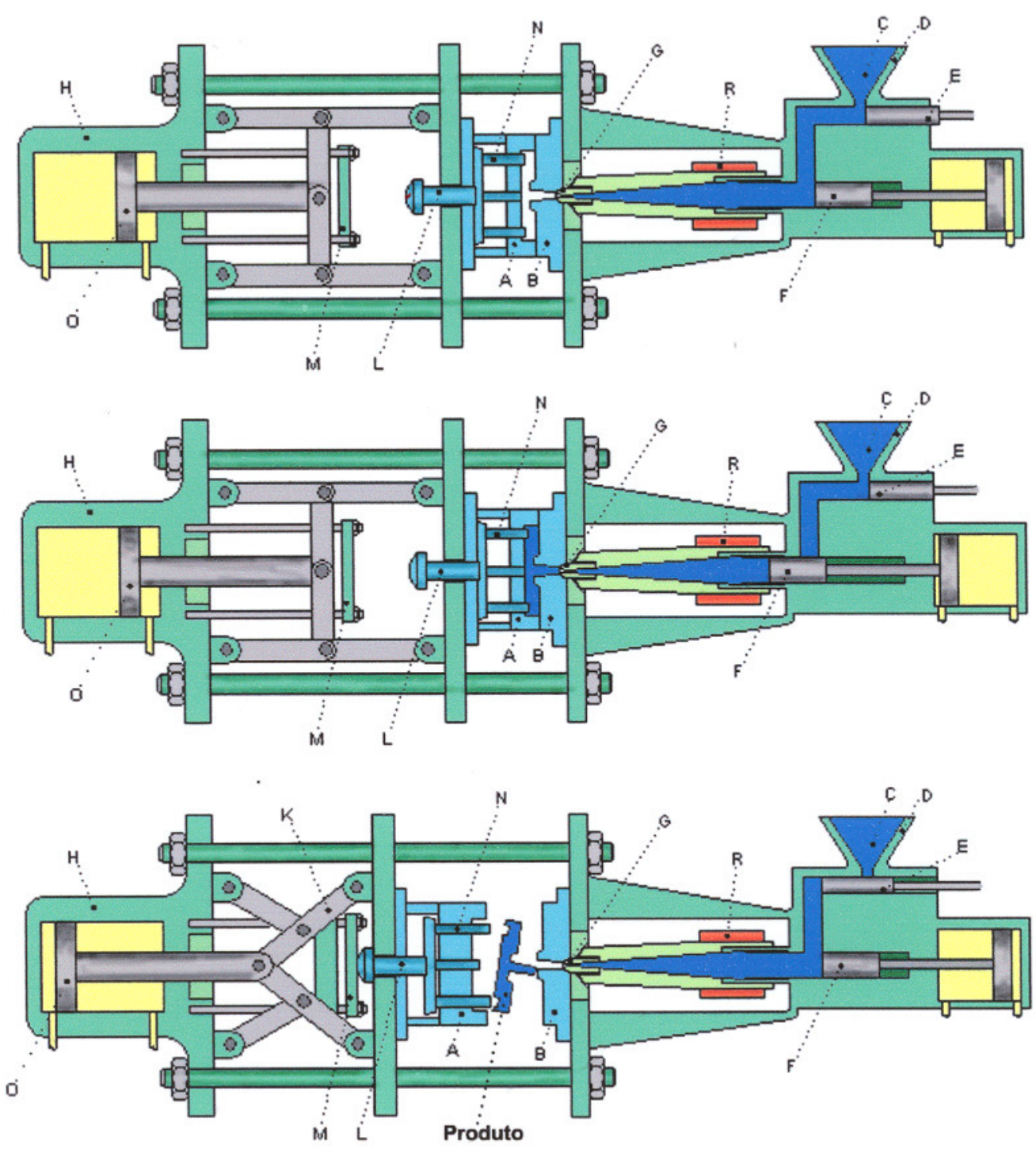

Figura 3.1 - Diagrama esquemático da moldagem por injeção (Sors et al,). 
Atualmente, para otimização da moldagem por injeção, as máquinas utilizadas dispõem de uma rosca-sem-fim que substitui o aríete. Nesse sistema, ilustrado na figura 3.2, o movimento rotativo da cavilha empurra o material para frente do cilindro, o atrito gera calor, que inicia o processo de fusão do material enquanto garante uma maior homogeneidade do material.

\section{Descrevendo o funcionamento da injetora}

$\mathrm{Na}$ vista superior da figura 3.1, $A$ e $B$ são partes do molde fechado. $\mathrm{O}$ material $C$ cai do tanque $D$ para o sistema de canais do canhão da máquina e é aquecido pelo conjunto de resistências $R$. Na vista central, pode-se visualizar que uma quantidade de material é prensada pelo aríete $F$ através da garganta da máquina para o centro do molde. Na vista inferior, o material para o ciclo seguinte é empurrado para frente pelo aríete $E$. No cilindro hidráulico $H$, o pistão com hastes $K$ puxa a parte móvel $A$ do molde para trás, a barra ejetora $L$ choca-se contra o amortecedor $M$ da máquina e os pinos ejetores $N$ ejetam o produto do molde. A máquina fecha as partes $A$ e $B$ e o ciclo recomeça.

$\mathrm{Na}$ figura 3.2, pode-se visualizar o esquema de funcionamento de uma unidade de injeção do tipo rosca-sem-fim, que é o tipo mais utilizado atualmente e que foi utilizado nesse trabalho. Nesse tipo de unidade, o material cai do reservatório $D$ sobre a rosca-sem-fim $F$ que gira e o empurra para frente; desta forma, o aquecimento do material é mais uniforme e a pressão de injeção obtida é maior.

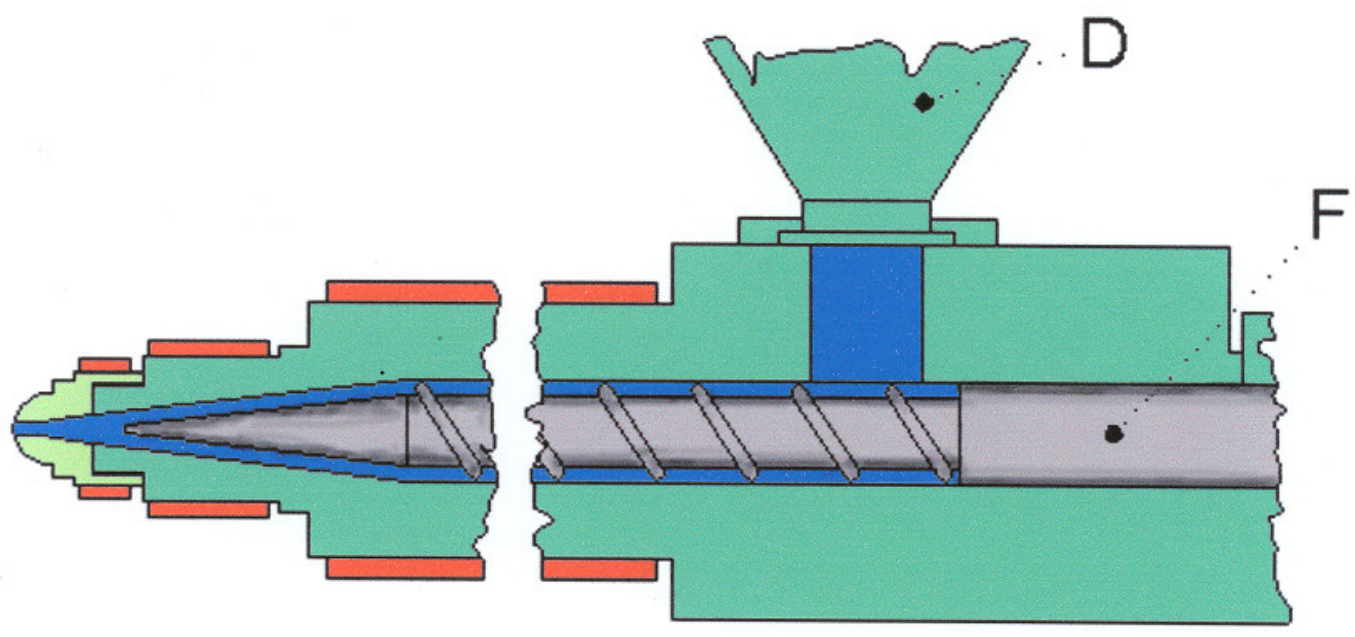

Figura 3.2 - Unidade de injeção do tipo rosca-sem-fim (Sors et al,). 


\section{3 - As Variáveis do Processo de Injeção de Termoplásticos}

Na década de 70, dizia-se não haver um modelo matemático que pudesse ser utilizado para descrever o processo de moldagem de termoplásticos por injeção (Rubin, 1972). Atualmente, apesar de existirem vários programas de computador capazes de simular o processo de moldagem por injeção, isso é apenas, na melhor das hipóteses, um meio termo entre a teoria, fundamentada em conceitos físicos, químicos e termodinâmicos, e o que realmente acontece na prática.

As razões tornam-se claras quando se analisa a maquinaria, materiais e processos envolvidos na injeção de termoplásticos. Muitos fatores que afetam o processo - temperatura do material, pressão, velocidades do material no cilindro da máquina e no molde, temperatura do molde e padrão de fluxo - não são medidos em sua totalidade ou não podem ser isolados continuamente para um efetivo controle do processo. Não há uma realimentação das variáveis do processo para compensar automaticamente as mudanças de condições.

O material plástico nunca é o mesmo. Ele tem diferentes pontos de liquefação, pesos moleculares, distribuição de peso molecular, graus de polimerização e impurezas. Durante o processamento o material é exposto ao ar atmosférico e é comprimido com ele no cilindro aquecido com variação na quantidade de material que pode sofrer degradação através da queima a cada ciclo.

As propriedades fisicas do material são geralmente não lineares com respeito à temperatura e velocidade. $O$ plástico é compressivel, deformável, elástico e suscetivel a mudanças de propriedades após ser removido do molde. Ele muda suas dimensões e propriedades após o processamento e estas propriedades podem ser diferentes, dependendo da direção na qual o material flui no molde em relação à peça injetada. $O$ plástico tem propriedades com dependência temporal, que são fortemente alteradas pelo ambiente no qual ele está inserido. Em alguns materiais variações no grau de cristalinidade não são previsíveis ou reproduziveis (Rubin, 1972).

Particularmente, no caso da injeção de lentes, as variáveis do processo têm uma enorme influência na qualidade das peças produzidas. As características finais de componentes para aplicação em óptica impõem uma série de exigências com respeito aos materiais que podem ser utilizados limitando o seu número.

Finalmente, determinar corretamente os padrões de fluxo, o que envolve o correto dimensionamento dos canais de distribuição e "gates", projetar um sistema de resfriamento eficiente e vencer os obstáculos apresentados pela contração do material durante o resfriamento da resina na cavidade do molde são as principais dificuldades encontradas na confecção de lentes injetadas. 


\section{4 - Reologia do Plástico Fundido}

A reologia trata da deformação da matéria. No caso de materiais poliméricos, quando aplicados à manufatura, a reologia é relacionada com a fase de deformação denominada fluxo. Para a área de processamento de plásticos, é de interesse o fluxo através de dutos cilíndricos ou retangulares, onde as condições de fluxo em um produto moldado são determinadas pelas buchas de entrada, canais, "gates" e cavidades.

Leis que regem o comportamento do fluxo de fluidos viscosos ou laminares, também conhecidas como fluxo Newtoniano, são conhecidas, porém, o comportamento dos materiais plásticos não concorda totalmente com as leis de fluxo Newtoniano, de forma que as equações deveriam ser modificadas para serem aplicáveis aos plásticos.

Um reômetro simples, como o esquematizado na figura 3.3, ajuda a entender como ocorre o fluxo de materiais plásticos. Os três materiais são submetidos a uma força genérica que os obriga a passar por um orificio de saída. Verifica-se que, quando um fluido como a água é forçado através de um orificio, tem-se a vazão assumindo a forma e tamanho do orifício. Quando um bloco de borracha vulcanizado é pressionado através da mesma abertura ele assume sua forma original do outro lado. Se o plástico derretido é forçado através do mesmo reômetro, a forma obtida na saída é maior em diâmetro do que a abertura. Esse comportamento, conhecido como viscoelasticidade, significa que plásticos fundidos agem parcialmente como borracha e parcialmente como fluido, ocorrendo aumento no diâmetro em relação ao orifício da saida após a passagem pelo reômetro.

Se todas as condições no reômetro permanecem as mesmas, a quantia ou volume de plástico fundido que passa através dele em um dado instante dependerá da resistência interna ao fluxo do material. Essa resistência é conhecida como viscosidade (Dym, 1987).

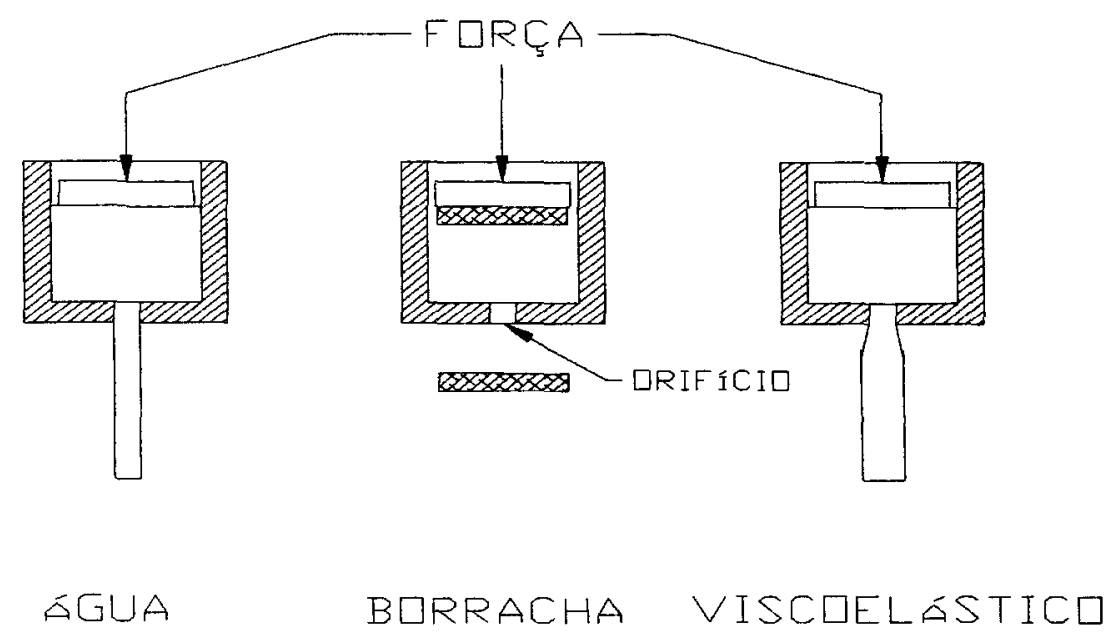

Figura 3.3 - Reômetro para análise do fluxo de materiais. 
Newton formulou uma hipótese para a viscosidade, idealizando materiais viscosos como consistindo de diminutas camadas paralelas conhecidas como camadas laminares.

Durante o fluxo de um material viscoso através de um tubo, a camada adjacente à parede do tubo adere a ele e não se move. A próxima camada move-se e desliza sobre a camada aderente à parede. As camadas remanescentes movem-se umas com respeito às outras a uma taxa crescente enquanto a distância da parede do tubo ao centro aumenta. Esse movimento imaginário de camadas conhecido como cisalhamento está esquematizado na figura 3.4.

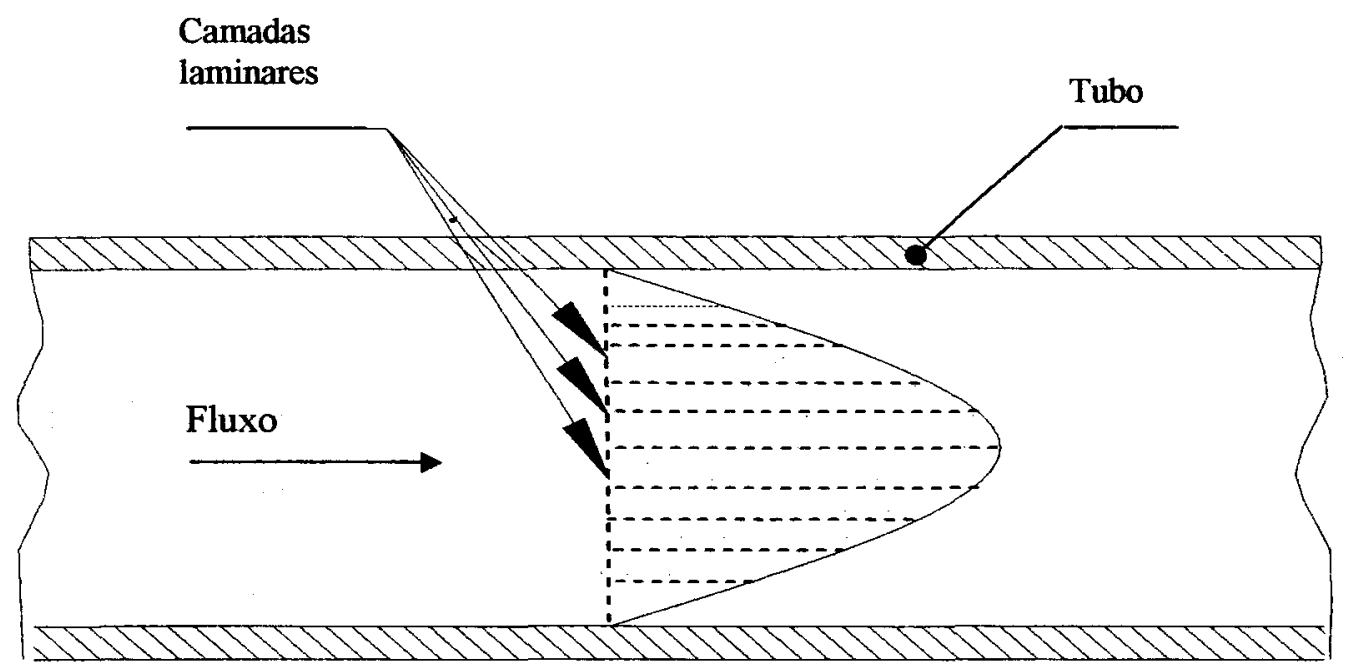

Figura 3.4 - Conceito gráfico do fluxo laminar.

As linhas tracejadas representam as camadas imaginárias que têm um movimento de deslizamento umas em relação às outras. A camada adjacente à parede do tubo tem sua velocidade retardada devido à aderência. À medida que as camadas afastam-se da parede, seu movimento torna-se gradativamente mais rápido.

O tipo de cisalhamento descrito ocorre no cilindro de injeção, nos canais, "gates" e cavidades. A unidade de pressão no fluido que é submetido à ação do cisalhamento é a tensão de cisalhamento enquanto que a velocidade do movimento entre as camadas, é a taxa de cisalhamento. Assim, a hipótese de Newton pode ser descrita pela relação:

$$
\text { Viscosidade }=\frac{\text { Tensão de cisalhamento }}{\text { Taxa de cisalhamento }},
$$

que pode ser expressa matematicamente como demonstrado nas equações abaixo.

$$
\text { Tensão de cisalhamento }=\frac{P R^{2} \pi}{2 \pi L}=\frac{P R}{2 L}
$$




$$
\begin{aligned}
& \text { Taxa de cisalhamento }=\frac{4 Q}{\pi R^{3}} \quad \text { (para dutos cilíndricos) } \\
& \text { Taxa de cisalhamento }=\frac{6 Q}{w h^{2}} \quad \text { (para dutos retangulares) }
\end{aligned}
$$

Sendo,

$$
\begin{aligned}
& Q=\text { quantidade de material }\left(\mathrm{m}^{3} / \mathrm{s}\right) ; \\
& R=\text { raio do cilindro através do qual ocorre o fluxo }(\mathrm{m}) ; \\
& L=\text { comprimento do cilindro }(\mathrm{m}) ; \\
& P=\text { Pressão }\left(\mathrm{kg} / \mathrm{m}^{2}\right) ; \\
& \mu=\text { viscosidade }\left(\mathrm{N} . \mathrm{s} / \mathrm{m}^{2}\right) ; \\
& h=\text { altura para dutos retangulares }(\mathrm{m}) ; \\
& w=\text { largura para dutos retangulares }(\mathrm{m}) .
\end{aligned}
$$

Que resulta na equação da viscosidade:

$$
\mu=\frac{\pi P R^{4}}{8 Q L} \quad \text { (para dutos cilíndricos). }
$$

Assim, a quantidade de material que entra na cavidade obedece às relações:

$$
\begin{aligned}
& Q=\frac{\pi P R^{4}}{8 \mu L} \quad \text { (para dutos cilindricos); } \\
& Q=\frac{P h^{4}}{9 \mu L} \quad(\text { com } w=2 h, \text { para dutos retangulares }) .
\end{aligned}
$$

Como foi dito anteriormente, o comportamento dos plásticos fundidos não é condizente com a hipótese de Newton. A viscosidade de materiais viscoelásticos muda com a mudança da tensão de cisalhamento e a relação entre a tensão de cisalhamento e a taxa de cisalhamento não é corretamente prevista pelas equações citadas. Além disso, materiais que não são sensíveis à taxa de cisalhamento, isto é, não têm suas moléculas alinhadas com o fluxo, apresentam aumento da viscosidade, enquanto que os materiais sensiveis à taxa de cisalhamento apresentam comportamento oposto.

Apesar desse comportamento contraditório do índice de viscosidade com relação às leis do fluxo newtoniano, as equações 3.5 e 3.6 podem ser úteis durante a fase de redimensionamento de dutos e canais de alimentação da cavidade do molde. Se for constatado, após testes iniciais, que um ajuste no raio ou na profundidade do "gate" se faz necessário, nota-se pelas equações 3.5 e 3.6 que um aumento de $10 \%$ no raio ou na profundidade permitiria um aumento de aproximadamente $47 \%$ no volume de material injetado no mesmo tempo. Considerações análogas podem ser feitas com relação ao 
comprimento dos dutos. Outro ponto a ser considerado é o fato de ser possivel a obtenção de um valor aproximado da viscosidade quando se estabelecem valores fixos de tempo de injeção, pressão e temperatura no processo de injeção e obtém-se, após vários ciclos, o mesmo volume de material liberado na cavidade. Com esse tipo de raciocinio, as leis do fluxo Newtoniano poderiam ser aplicadas para valores específicos de pressão, temperatura e viscosidade relativas.

\section{5 - A Moldagem por Injeção na Indústria}

A indústria de produtos termoplásticos se utiliza em sua maioria de moldes que são projetados com base na experiência prática adquirida pelos profissionais envolvidos. Dessa forma, a ferramenta é normalmente construída para que suporte esforços muito acima daqueles que ela realmente irá sofrer durante a sua vida útil. Os materiais utilizados são aqueles que a experiência de gerações passadas comprovou serem adequados para a utilização em questão. O sistema de refrigeração normalmente é projetado seguindo-se normas pré-estabelecidas quanto às dimensões dos dutos e ao seu distanciamento da cavidade. Durante o processo de injeção a máquina injetora é ajustada através de sucessivas alterações nos parâmetros de tempo, temperatura e pressão até que se obtenha peças injetadas com as características desejadas. Resumindo, qualquer cálculo mais complexo é desprezado, optando-se geralmente pela prática.

É certo que a tarefa de selecionar os materiais mais adequados para a construção de um molde de injeção exige uma consideração multifacetada. No entanto, como resultado da seleção errônea dos materiais, várias operações extras podem ser necessárias, como por exemplo, a retífica de partes do molde distorcidas ou a recuperação de rachaduras. A maioria dos construtores de molde tem seu próprio modelo, que prescreve automaticamente o material mais adequado para as partes do molde.

É necessário dizer que o incentivo para um dimensionamento mais correto é pequeno. Não há duvida de que já têm sido projetados e construídos moldes que funcionam bem, sem quaisquer cálculos reológicos e parece que o dimensionamento de canais de distribuição e "gates" entre outros, ao invés da estimativa e uso de valores experimentais, é apenas uma desnecessária perda de tempo. Entretanto, não há atenção especial em relação às dúvidas quanto à energia utilizada desnecessariamente pelo molde ou ao tempo de duração de seu ciclo de operações acima do necessário.

\section{6 - Moldagem por Injeção-Compressão}

O processo de injeção permite a obtenção de peças com elevada precisão dimensional. A obtenção de tal precisão depende, dentre outros fatores, de uma máquina 
injetora que possibilite ciclos seguramente reproduziveis. Ciclos que incluem plastificação, dosagem e injeção da resina, aplicação de pressão de fechamento e resfriamento adequados.

Para a obtenção e manutenção dos niveis desejados de precisão durante o processo de fabricação de peças injetadas, é necessário um projeto do componente a ser injetado e do molde que, sob certos aspectos, influenciam mais o processo do que a própria máquina injetora. Durante a fase de projeto do componente e de projeto e construção do molde, é importante considerar-se parâmetros tais como: pontos de entrada e canais de distribuição da resina fundida, dutos de refrigeração que promovam um bom preenchimento e resfriamento da peça a ser moldada.

Os parâmetros citados acima influem decisivamente na qualidade das peças moldadas no que se refere às características macroscópicas, ou seja, aquelas características que podemos avaliar de forma visual como acabamento geral da peça, preenchimento total da cavidade do molde e a presença de manchas ou bolhas de ar ou ainda através de instrumentos de medidas com a precisão da ordem de $10^{-3} \mathrm{~mm}$. No entanto, outros fatores afetam a qualidade de produtos injetados. No caso particular da injeção de componentes ópticos, uma caracteristica adicional desejada para a peça produzida é a ausência de tensões residuais.

$\mathrm{Na}$ injeção de lentes as tensões residuais resultantes do processo afetam a qualidade da imagem obtida por essa lente devido ao fenômeno da birrefrigência. Outro caso, em que a birrefrigência afeta a qualidade do componente moldado, é a injeção dos "compact disks" (CD's).

Uma forma de prevenir o surgimento de tensões residuais é através do processo de moldagem por injecão-compressão. Nesse processo, a resina fundida é injetada dentro do molde parcialmente fechado. A abertura entre as placas varia de acordo com a peça moldada, podendo assumir valores de 1 a $20 \mathrm{~mm}$ ou até $50 \mathrm{~mm}$ para certas peças. Somente após a injeção se completar é que o molde é fechado completamente, portanto, exige-se para esse processo que o molde seja positivo, ou seja, qualquer reentrância ou ângulo presente na peça moldada deve ser favorável ao movimento de aproximação ou afastamento das placas do molde que envolvem a cavidade.

Devido às largas correntes de fluxo presentes durante a injeção no interior da cavidade parcialmente aberta, a pressão de injeção necessária para o processo de injeçãocompressão é de 5 a 10 vezes menor do que na injeção convencional. Mesmo durante a conformação subseqüente do bolo de resina fundida, a pressão no interior da cavidade e a tensão de cisalhamento sobre a resina permanecem baixas. Por essa razão, as peças moldadas por injeção-compressão fícam virtualmente livres de tensões residuais (PLÁSTICO INDUSTRIAL, Fev/2001). 
Para a eficácia do processo de injeção-compressão é necessário que exista um perfeito sincronismo entre as etapas de injeção e fechamento final das placas do molde. Temse, então, a sobreposição dos dois processos que devem ser perfeitamente reproduzíveis a cada ciclo. Como conseqüência dessa necessidade, deve-se observar os seguintes requisitos para a injetora:

- A máquina deve ser equipada com sistemas de medição com alta resolução e velocidade de resposta para determinação precisa de posicionamentos, velocidades e pressões;

- Para que o sistema de controle seja efetivo durante os curtos tempos envolvidos no processo de injeção, são necessárias uma alta taxa de varredura e rápida conversão das leituras em variáveis processáveis;

- A máquina precisa ser dotada de um sistema hidráulico que apresente uma resposta rápida capaz de seguir as alterações das variáveis do processo que são controladas.

Com relação aos dois primeiros itens não existem maiores complicações, sendo necessário apenas instalar sensores e sistemas de leituras adequados. Contudo, o último item apresenta obstáculos dificeis de serem superados, sendo necessária a existência de um sistema hidráulico que na maioria dos casos não é comum a todas as máquinas injetoras. $\mathbf{O}$ projeto detalhado desse sistema hidráulico foge aos objetivos desse trabalho é não sérá descrito. Entretanto, é importante salientar que a adequação de uma máquina injetora seria compensada pelas vantagens decorrentes do processo que, para a injeção de lentes, refletiriam em uma redução significativa na birrefrigência e na melhoria da homogeneidade óptica, o que resultaria em lentes de melhor qualidade.

\section{7 - Dados Técnicos e Notas sobre a Injeção de Plásticos}

$\mathrm{Na}$ injeção de materiais termoplásticos cada um dos materiais utilizáveis no processo apresenta características únicas. Ao final do processo, essas características em conjunto irão conferir ao produto qualidades que poderão ou não torná-lo adequado à aplicação desejada.

Certos parâmetros dizem respeito apenas às propriedades fisicas do material. Propriedades que são inerentes à sua estrutura molecular e que permitem, quando o material é processado corretamente, especificar precisamente, condições seguras de trabalho do componente. A resistência ao impacto, o coeficiente de expansão térmica e a resistência à tração do material são alguns exemplos dessas propriedades.

Outros parâmetros referem-se a certas propriedades que não podem ser desconsideradas durante a fase de projeto do molde e durante o processamento do material. $\mathrm{O}$ projeto incorreto do molde ou a escolha errônea de parâmetros na máquina injetora interferem decisivamente na qualidade final do componente injetado. Como exemplo desses 
parâmetros, pode-se citar o percentual de contração da peça moldada durante o resfriamento, a temperatura de fusão e a condutividade térmica. Dessa forma, a escolha incorreta da temperatura, pressão de injeção e tempo de resfriamento na máquina injetora traz como resultado a degradação do material ou o incorreto preenchimento da cavidade.

No caso particular da injeção de elementos ópticos, principalmente lentes, qualquer alteração na estrutura molecular do polímero apresenta uma alteração direta nas características finais do produto, resultando na perda do componente. As dificuldades inerentes ao processo de injeção fazem com que a produção de componentes injetados de elevada qualidade para aplicação óptica seja por vezes tão complexa que o domínio das técnicas de injeção passe a ser considerado como segredo industrial pelos fabricantes.

Com o objetivo de orientar o projeto do molde, bem como o processo inicial de injeção, é importante a pesquisa dos dados técnicos relacionados. Livros especializados, bem como, fabricantes de resinas e construtores de máquinas injetoras fornecem esses dados que são fundamentais para a o projeto do molde e eficiência do processo.

Algumas propriedades fisicas importantes para o processo de injeção do acrílico e do poliestireno estão relacionadas na tabela 3.1. A tabela 3.2 relaciona valores de parâmetros utilizados para ajustes iniciais da máquina injetora.

Tabela 3.1 - Propriedades físicas do acrílico e poliestireno

\begin{tabular}{|l|c|c|}
\hline \multicolumn{1}{|c|}{ Propriedade } & Acrílico & Poliestireno \\
\hline Calor Específico & $1260\left(\mathrm{~J}_{\mathrm{Kg}} \mathrm{Kg}^{-1} \cdot \mathrm{K}^{-1}\right)$ & $1345\left(\mathrm{~J} \cdot \mathrm{Kg}^{-1} \cdot \mathrm{K}^{-1}\right)$ \\
\hline Condutividade Térmica & $0,17-0,25\left(\mathrm{~W} / \mathrm{m}^{0} \mathrm{C}\right)$ & $0,11-0,14\left(\mathrm{~W} / \mathrm{m}^{0} \mathrm{C}\right)$ \\
\hline Contração & $0,2-0,8 \%$ & $0,2-0,6 \%$ \\
\hline Peso Específico & $1,19 \mathrm{~g} / \mathrm{cm}^{3}$ & $1,20-1,33\left(\mathrm{~g} / \mathrm{cm}^{3}\right)$ \\
\hline Temperatura de Fusão & $204-254\left(^{\circ} \mathrm{C}\right)$ & $\left.163-260{ }^{\circ} \mathrm{C}\right)$ \\
\hline Temperatura de Transição Vitrea & $80-120\left({ }^{\circ} \mathrm{C}\right)$ & $90-105\left(^{\circ} \mathrm{C}\right)$ \\
\hline Temperatura para Alívio de Tensões & $74-92\left({ }^{\circ} \mathrm{C}\right)$ & $93\left({ }^{\circ} \mathrm{C}\right)$ \\
\hline
\end{tabular}

A literatura especializada fornece detalhes importantes que devem ser considerados na fase de projeto de moldes para injeção (Dym, 1987). Procurou-se sintetizar os dados que apresentam maior relevância para o trabalho atual:

- Para ciclos longos e seções espessas, deve-se utilizar uma temperatura de cilindro mais baixa e taxas de injeção mais lentas;

- Em alguns materiais termicamente sensíveis, tais como policarbonatos, e em canais de alimentação longos, é desejável que existam pequenos poços frios no final dos 
canais ou em suas ramificações para prevenir que o material frio atinja a cavidade. Isso é especialmente importante para produtos ópticos;

- A localização incorreta do "gate" é responsável por vários defeitos, dentre eles o aprisionamento de gases e o efeito de jateamento nas peças injetadas, colocando em risco a qualidade do produto, principalmente quando se trata de produtos ópticos. Considerando-se que a região do "gate" é uma região tensionada, ele deveria ser colocado de forma que não possua uma orientação no que diz respeito às funções do produto. Se a peça é redonda e a concentricidade é importante, um "gate" central é indicado. Se a peça é oblonga e se a possibilidade de distorção existe, o "gate" deveria ser colocado de forma que o material alcance as regiões periféricas ao mesmo tempo para evitar variação na taxa de resfriamento. Isso pode ser realizado pela leve variação no canal principal para um ponto mais afastado a fím de produzir um fluxo que simule um padrão em forma de guarda-chuva;

- aprisionamento de gases é um subproduto da usinagem não uniforme da cavidade ou do padrão de fluxo na cavidade. Esses defeitos podem ser corrigidos pelo polimento da área com linhas direcionais para conformar um padrão de fluxo. Uma outra importante consideração é colocar o "gate" em posição tal que o fluxo, entrando na cavidade, seja defletido por uma saliência ou pela parede do molde cerca de 1/8" a $3 / 16$ " do "gate";

- Polímeros sensíveis à taxa de cisalhamento têm suas moléculas alinhadas com o fluxo;

- Polímeros insensíveis à taxa de cisalhamento são danificados quando a tensão de cisalhamento aumenta.

Tabela 3.2 - Parâmetros para processamento do acrílico e do poliestireno

\begin{tabular}{|l|c|c|}
\hline \multicolumn{1}{|c|}{ Parâmetro } & Acrílico & Poliestireno \\
\hline Contra-pressão & $400-800(\mathrm{psi})$ & $500-1500(\mathrm{psi})$ \\
\hline Temperatura de Secagem & $77-93\left(^{\circ} \mathrm{C}\right)(2 \mathrm{hs})$ & $77-82\left(^{\circ} \mathrm{C}\right)(2 \mathrm{hs})$ \\
\hline Temperatura do Molde & $10-104\left({ }^{\circ} \mathrm{C}\right)$ & $10-38\left(^{\circ} \mathrm{C}\right)$ \\
\hline Torque do Parafuso & alto & baixo \\
\hline Velocidade do Parafuso & $40-60(\mathrm{rpm})$ & $50-200(\mathrm{rpm})$ \\
\hline
\end{tabular}

Para as resinas termoplásticas utilizadas, a literatura indica as dimensões mais adequadas para o "gate", canais e saídas de gases, conforme indicado na tabela 3.3 , onde " $E$ " é o valor médio da parede da peça a ser injetada. A contra-pressão é a pressão que indica o 
trabalho de misturar e, em alguma extensão, de cisalhar o polímero na preparação para injeção. Para melhor compreensão dos itens listados na tabela 3.3, deve-se consultar a figura 4.2 , onde está ilustrada a localização desses itens com relação à cavidade do molde.

Tabela 3.3 - Parâmetros para injeção de acrílico e poliestireno (Dym, 1987)

\begin{tabular}{|l|c|c|}
\hline \multicolumn{1}{|c|}{ Parâmetro } & Acrilico & Poliestireno \\
\hline Dimensões de "gates" & $\mathrm{L}=0,5 E$ & $\mathrm{~L}=0,33 E$ \\
$\mathrm{~L}=$ largura, C = comprimento & $\mathrm{C}=2 E$ & $\mathrm{C}=2 E$ \\
\hline Dimensões dos canais & $\varnothing 6,5-\varnothing 9,5(\mathrm{~mm})$ & $\varnothing 3,2-\varnothing 9,5(\mathrm{~mm})$ \\
\hline Profundidade da saída de gases & $0,07(\mathrm{~mm})$ & $0,05(\mathrm{~mm})$ \\
\hline Contra-pressão & $400-800(\mathrm{psi})$ & $500-1500(\mathrm{psi})$ \\
\hline
\end{tabular}




\section{4 - SIMULAÇÕES NUMÉRICAS}

\section{1 - Introdução}

O avanço constante da tecnologia dos computadores ocasionou o surgimento de softwares dedicados, voltados para diversas áreas do conhecimento. É o caso dos programas de computadores utilizados para cálculos de estruturas na construção civil, de resistência de elementos mecânicos utilizados por engenheiros mecânicos, de programas dedicados ao projeto de sistemas ópticos, dentre tantos outros.

$\mathrm{Na}$ área de injeção de termoplásticos, tem-se experimentado um avanço significativo dos programas de simulação de injeção. Os programas atuais aliados a uma maior velocidade dos microcomputadores tem tornado o uso dessa ferramenta muito útil para uma abordagem mais aprofundada do processo de injeção. Entretanto, como foi dito no item 3.2, muitas são as variáveis envolvidas no processo de injeção; isso faz com que os programas não consigam reproduzir com fidelidade as condições reais do processamento dos termoplásticos. Esse fato, aliado ao relativo sucesso alcançado pela indústria de termoplásticos com uma abordagem mais empírica dos problemas surgidos durante o processo de injeção, torna essa ferramenta pouco utilizada. Esse relativo desinteresse faz com que a pesquisa que tem sido realizada para um maior desenvolvimento dessa interessante ferramenta e a sua utilização sejam deixadas em um plano ocupado apenas por indivíduos ou empresas interessados em obter conhecimentos mais sólidos do processo de forma a obter subsídios mais eficazes na solução dos problemas encontrados na injeção de termoplásticos.

$\mathrm{Na}$ fase de projeto do molde para as lentes, utilizou-se o programa "3D Cmold" para a simulação numérica do processo de injeção. Embora se utilize uma versão de avaliação do programa, que não permite a simulação do processo de injeção como o polimetacrilato de metila, foram realizadas simulações com o poliestireno. Essas simulações permitiram obter os parâmetros relacionados com o processo de injeção da lente, as quais demonstraram teoricamente a adequação do projeto do molde à finalidade desejada. Neste capítulo são apresentados os resultados obtidos através dessas simulações.

\section{2 - Modelo Computacional da Lente e Canais do Molde}

Para a realização das simulações foi necessária a construção de um modelo tridimensional computacional da cavidade e canais do molde. Esse modelo, que pode ser visualizado na figura 4.1, foi construido utilizando-se o software dedicado "Mechanical Desktop". O modelo e os valores de pressão de injeção, de temperatura de fusão do plástico e de temperatura do molde foram utilizados para alimentar o programa de simulação. Com a 
entrada desses dados, o programa realiza intenso processamento, gerando diagramas que permitem a visualização do comportamento de parâmetros como padrão de fluxo e taxa de resfriamento entre outros. $O$ programa gera ainda no final da simulação um relatório indicando, se for o caso, pontos críticos e necessidades de ajustes na localização ou dimensionamento de canais e "gates" e na temperatura do material e/ou do molde.

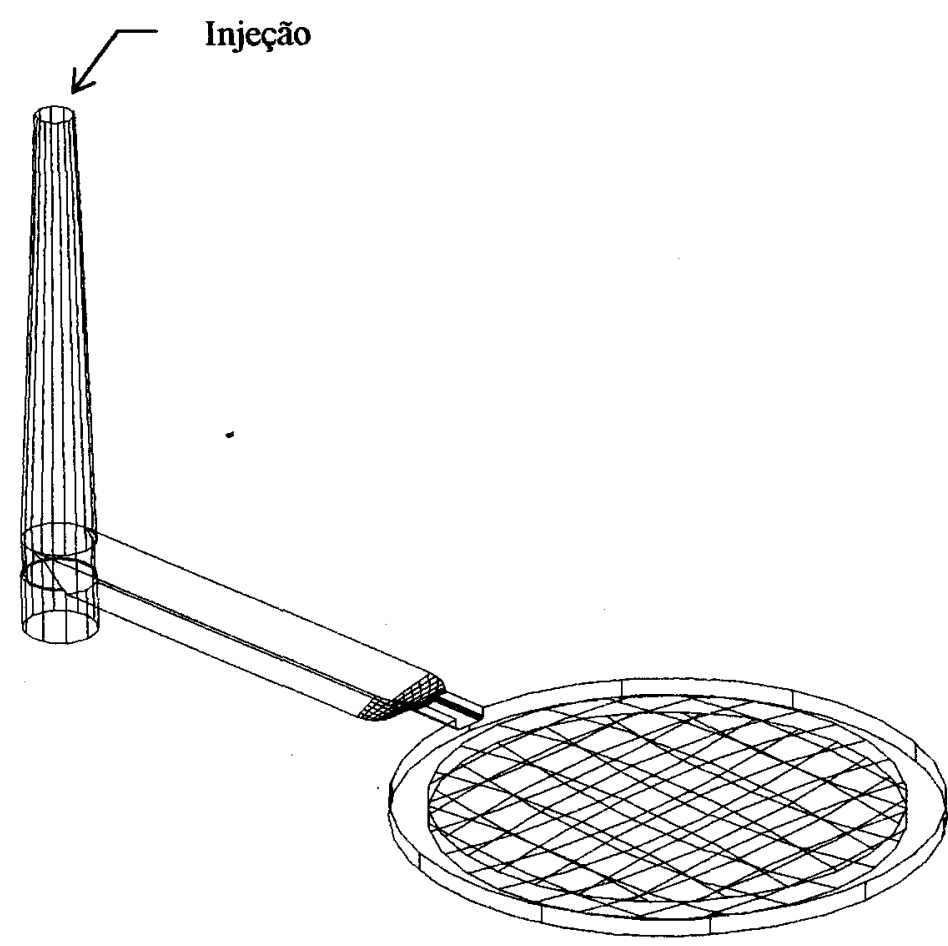

Figura 4.1 - Modelo tridimensional da lente e canais do molde

\section{3 - Resultados Obtidos na Simulação da Injeção}

A figura 4.2 apresenta o padrão de preenchimento do material fundido através dos canais de entrada, "gate" e cavidade. É interessante observar que a periferia da lente será preenchida por último (conforme a tabela fornecida pelo simulador a fase em vermelho será preenchida 0,77 segundos após o início da injeção) assim, o tempo total para preenchimento da cavidade é muito pequeno e para efeitos práticos não causa maiores problemas. A análise do padrão de preenchimento permite também encontrar os melhores pontos para colocação dos pequenos canais, que são necessários para a saida dos gases. De fato, o simulador se aproveita desse tipo de análise para revelar as regiões onde haverá o acúmulo de gases durante a injeção e que portanto necessitarão de canais para liberação desses gases. A incorreta localização desses canais ou a sua ausência podem provocar o superaquecimento dos gases e a degradação do polímero, inutilizando o produto. 


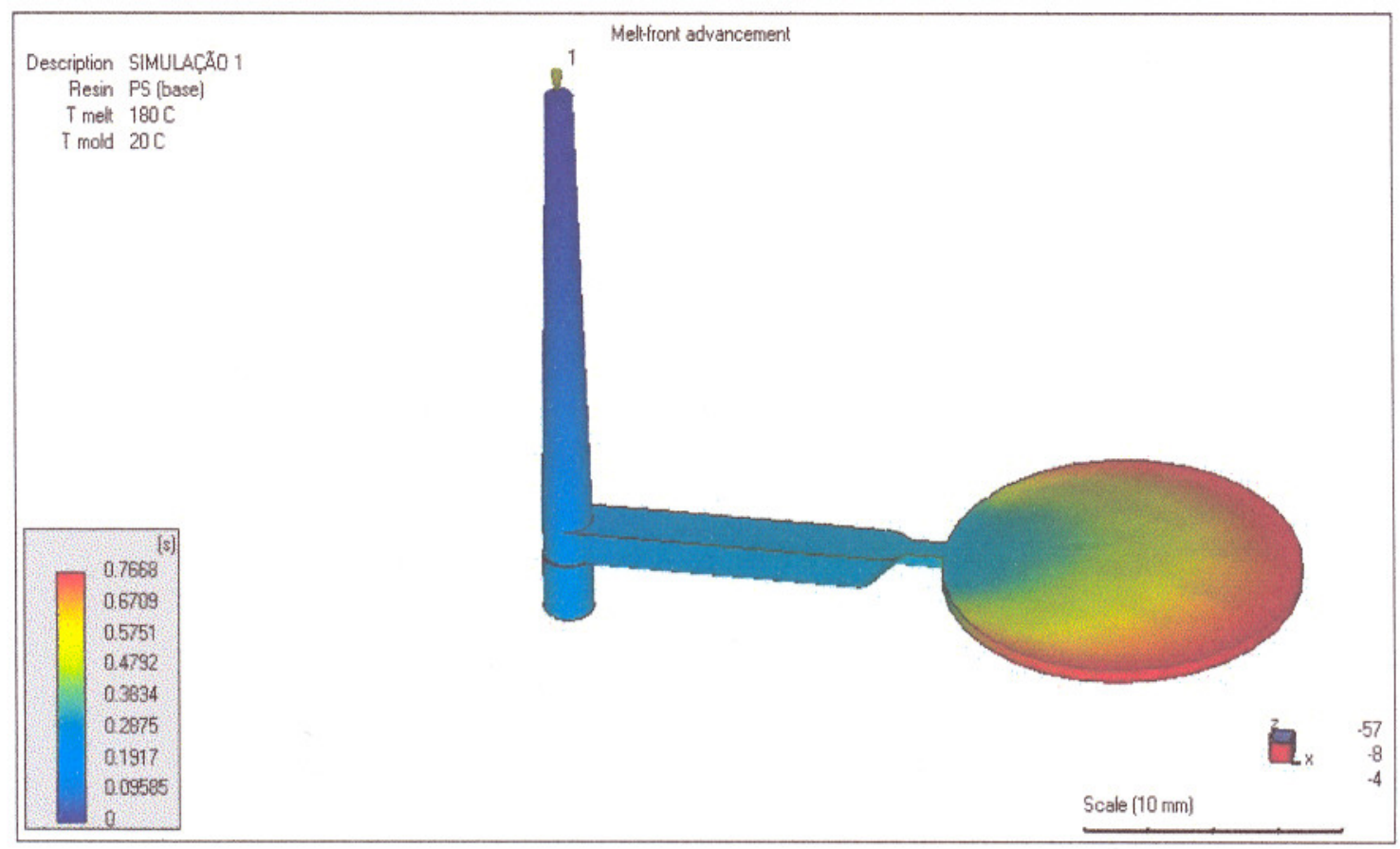

Figura 4.2 - Padrão de preenchimento da cavidade

A figura 4.3 apresenta o tempo de resfriamento para as várias regiões da lente. Esses resultados foram calculados pelo programa com base na temperatura de fusão de $180{ }^{\circ} \mathrm{C}$ e temperatura do molde de $20^{\circ} \mathrm{C}$, temperaturas sugeridas para a injeção do poliestireno. Para o polimetacrilato de metila, a temperatura do molde é mantida em aproximadamente $60{ }^{\circ} \mathrm{C}$ e a temperatura de fusão em $220^{\circ} \mathrm{C}$. Esses valores diferem significativamente daqueles fornecidos para simulação, porém, é interessante a análise qualitativa que se faz a partir desses dados. Como já era previsto, o centro da lente, possuindo maior espessura, consumirá um tempo maior para o seu resfriamento. Esse padrão de resfriamento produziria tensões internas que afetariam a qualidade da lente. Esse fato é altamente indesejável e, é devido a isso, que no projeto da refrigeração um dos dutos passa muito próximo desse ponto crítico, como poderá ser visto na montagem do molde na figura 5.4.

A figura 4.4 apresenta o gradiente de temperatura através dos canais e da cavidade após a etapa de injeção ser concluída. Esse resultado não é condizente com o que se espera na prática. A zona do "gate", possuindo uma seção estreita, deveria apresentar temperatura mais baixa que a zona central, que é mais espessa. Outras simulações apresentaram o mesmo resultado que pode ser devido a alguma falha no programa. Os pontos na cor violeta são as posições adequadas para a colocação das saídas dos gases. 


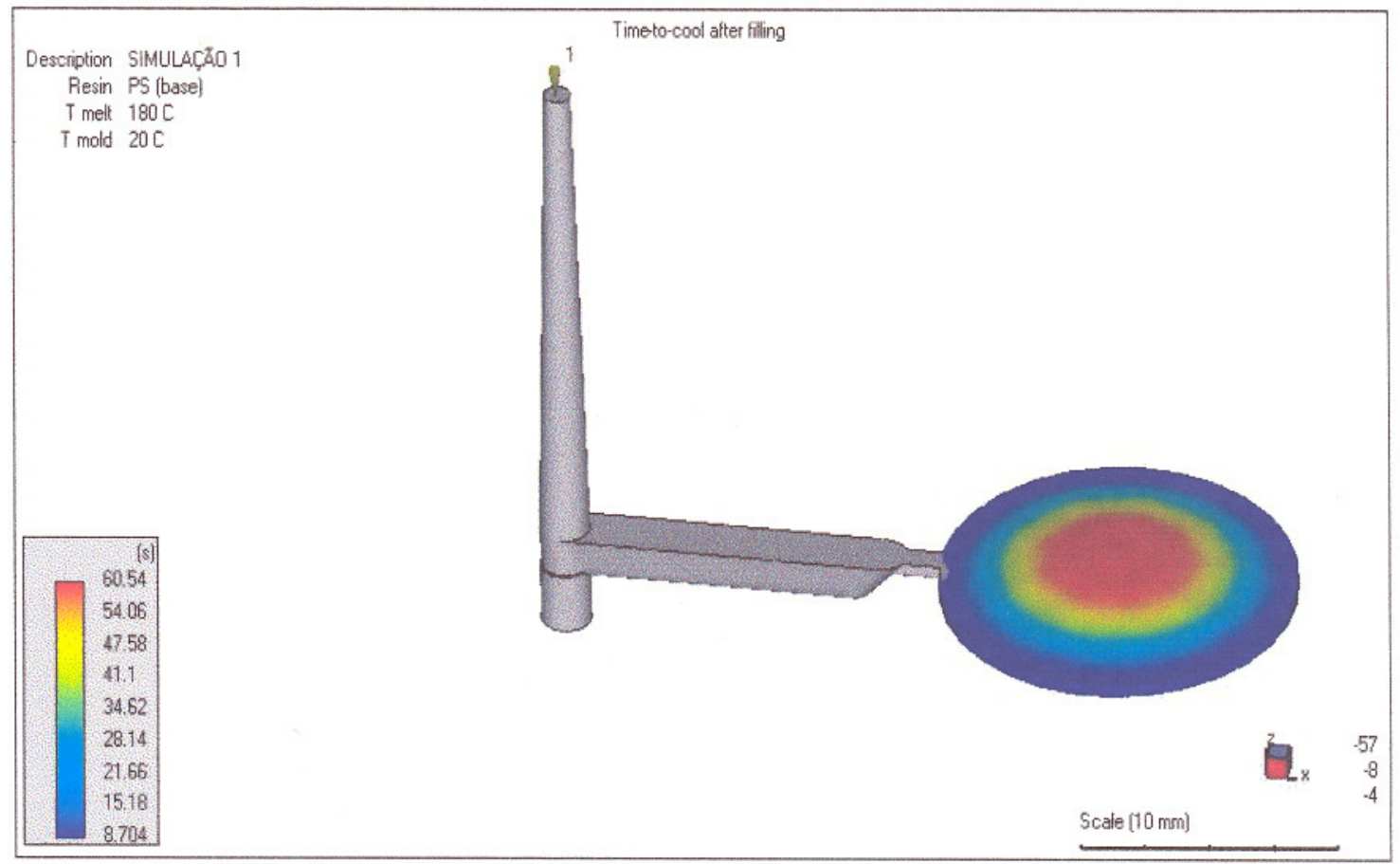

Figura 4.3 - Padrão de resfriamento

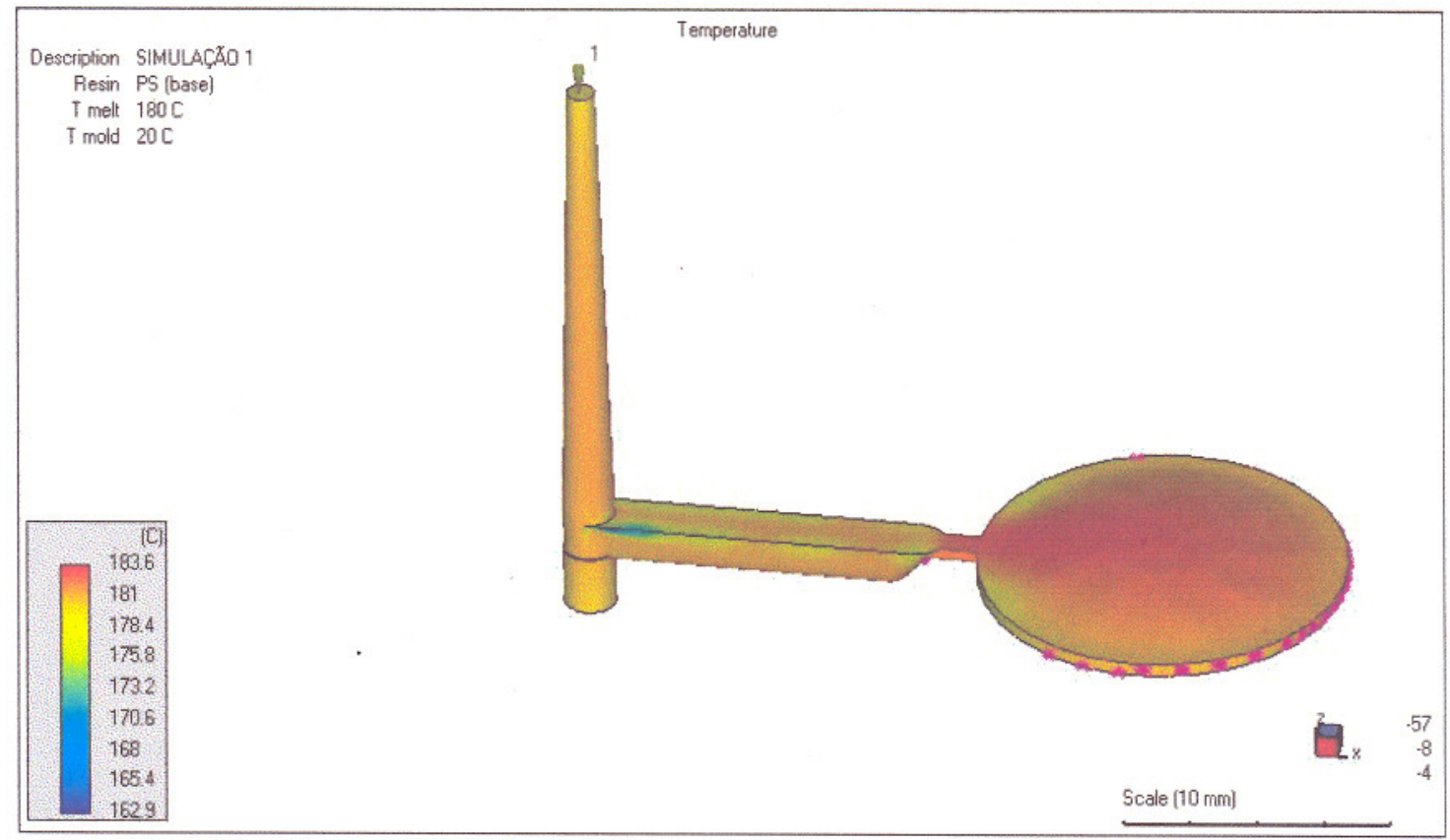

Figura 4.4 - Gradiente de Temperatura e saída de gases

Na figura 4.5 pode-se verificar a orientação das cadeias poliméricas. Durante o estágio de preenchimento no processo de injeção, as cadeias poliméricas são orientadas em uma direção influenciada pelo fluxo e de acordo com a taxa de cisalhamento. A simulação demonstra uma orientação uniforme das cadeias, o que é desejável para uma melhor uniformidade do produto. 


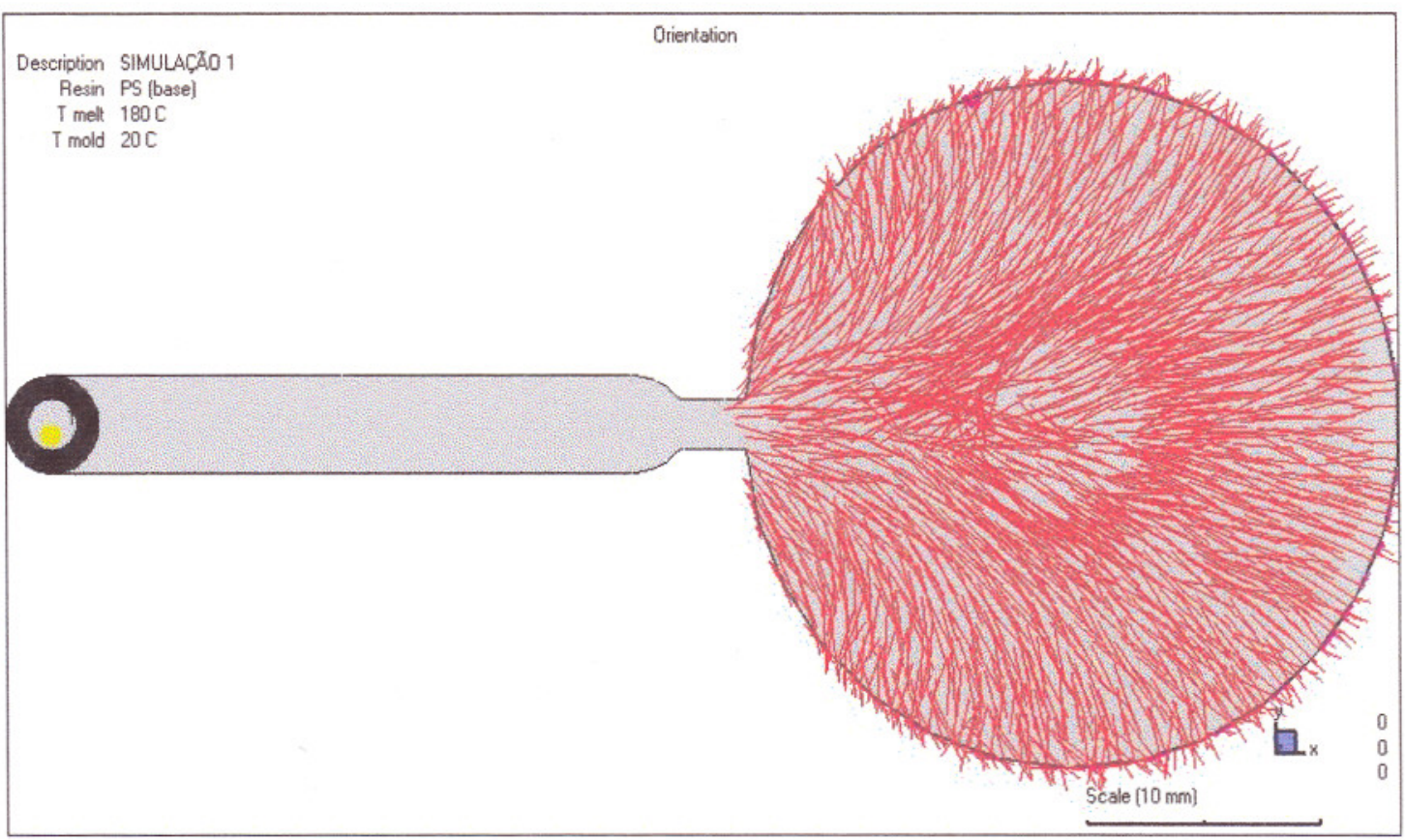

Figura 4.5 - Orientação das cadeias poliméricas

Alguns dados relativos à lente e aos parâmetros de máquina, que foram também obtidos através da simulação numérica, podem ser vistos na tabela 4.1.

Tabela 4.1 - Parâmetros obtidos na simulação

\begin{tabular}{|l|c|}
\hline Volume da lente & $11.79 \mathrm{~cm}^{3}$ \\
\hline Volume total bucha/canais/gate & $4.65 \mathrm{~cm}^{3}$ \\
\hline Área total projetada & $29.27 \mathrm{~cm}^{2}$ \\
\hline Espessura média da lente & $5.10 \mathrm{~mm}$ \\
\hline Tempo de preenchimento & $0.77 \mathrm{~s}$ \\
\hline Tempo de recalque & $10.09 \mathrm{~s}$ \\
\hline Tempo de resfriamento & $49.96 \mathrm{~s}$ \\
\hline Tempo de resfriam. do canal & $3.81 \mathrm{~s}$ \\
\hline Máxima pressão de injeção & $19.90 \mathrm{MPa}$ \\
\hline Pressão de recalque & $15.92 \mathrm{MPa}$ \\
\hline Temperatura do material & $180.00 \mathrm{C}$ \\
\hline Força de fechamento & $4.75 \mathrm{TON}(\mathrm{min})$. \\
\hline Carga requerida(GPS) & $17.56 \mathrm{~g}$ \\
\hline Pressão de injeção máxima & $180.00 \mathrm{MPa}$ \\
\hline Taxa de injeção máxima & $29.63 \mathrm{~cm}^{3} / \mathrm{s}$ \\
\hline
\end{tabular}




\section{5 - PROJETO E CONSTRUÇÃO DO MOLdE PARA INJEÇÃO DAS LENTES}

\section{1 - Introdução}

O projeto de um molde pode ser descrito resumidamente em três etapas: dimensionamento geral, escolha de materiais e o projeto dos sistemas de extração e refrigeração. No que se refere ao dimensionamento, o ponto mais crítico é sem dúvida o dimensionamento dos canais que alimentarão a cavidade com a resina fundida. $\mathrm{O}$ projeto dos sistemas de extração e refrigeração normalmente não apresentam maiores complicações, exigindo apenas bom senso e criatividade para contornar os problemas de posicionamento com relação à cavidade do molde. É importante salientar mais uma vez, como foi exposto no item 3.2, que muitas são as variáveis envolvidas no processo de injeção, o que torna o projeto de moldes extremamente árduo se o objetivo for projetar um molde apoiado inteiramente em fórmulas e teorias. $\mathrm{O}$ problema é que todo esse trabalho pode ser inócuo devido à enorme quantidade de variáveis presentes e à falta de controle ou monitoramento de grande parte delas. Partindo desse pressuposto, os cálculos relacionados ao projeto foram restritos àqueles que apresentam real relevância para o resultado final que é a confecção de lentes com boa qualidade óptica.

O item 5.2 traz uma análise qualitativa da lente a ser injetada; aborda-se a seguir, no item 5.3, o projeto do sistema de refrigeração e canais. No item 5.4, é apresentado o projeto do sistema de refrigeração e alguns cálculos relacionados. No item 5.5 faz-se uma descrição da construção do molde.

\section{2 - Análise da Lente como Produto da Injeção}

Quando se considera uma lente como produto para injeção, observa-se que é um produto muito favorável ao processo no que se refere à geometria da cavidade. Normalmente, uma lente não possui reentrâncias que dificultem a extração, o que torna 0 projeto relativamente simples do ponto de vista mecânico. Para esse projeto, o produto em questão é uma lente em acrilico com as dimensões descritas na figura 5.1.

A área útil da lente é aquela compreendida pelo círculo de diâmetro igual a $50 \mathrm{~mm}$. $\mathrm{O}$ aro externo com o diâmetro de $56 \mathrm{~mm}$ tem a dupla função de servir como área para extração da lente do molde e como ponto de fixação da lente nos equipamentos ou suportes específicos à aplicação desejada.

Quando se deseja fabricar um produto pelo processo de moldagem por injeção, o seu projeto normalmente prevê paredes e reforços que garantem, ao mesmo tempo, a necessária 
resistência mecânica e a uniformidade na espessura geral do produto, isto é, qualquer seção da cavidade a ser preenchida pela resina terá aproximadamente a mesma espessura. Uma lente apresenta o inconveniente de possuir necessariamente variação na sua espessura. Isto ocasiona variações em valores absolutos na contração de cada região da lente durante o resfriamento, deformando a superfície. Pelo exposto, torna-se necessário um sistema de resfriamento, o qual favoreça uma maior velocidade de resfriamento na região de maior espessura que é a região central da cavidade; permitindo, assim, que a máquina injetora possa compensar a contração do material injetando mais resina antes que o ponto de entrada com menor seção esteja solidificado. Outra observação a ser feita é sobre o elevado volume da lente, tornando-se necessário projetar os canais de forma adequada para uma correta alimentação da cavidade.

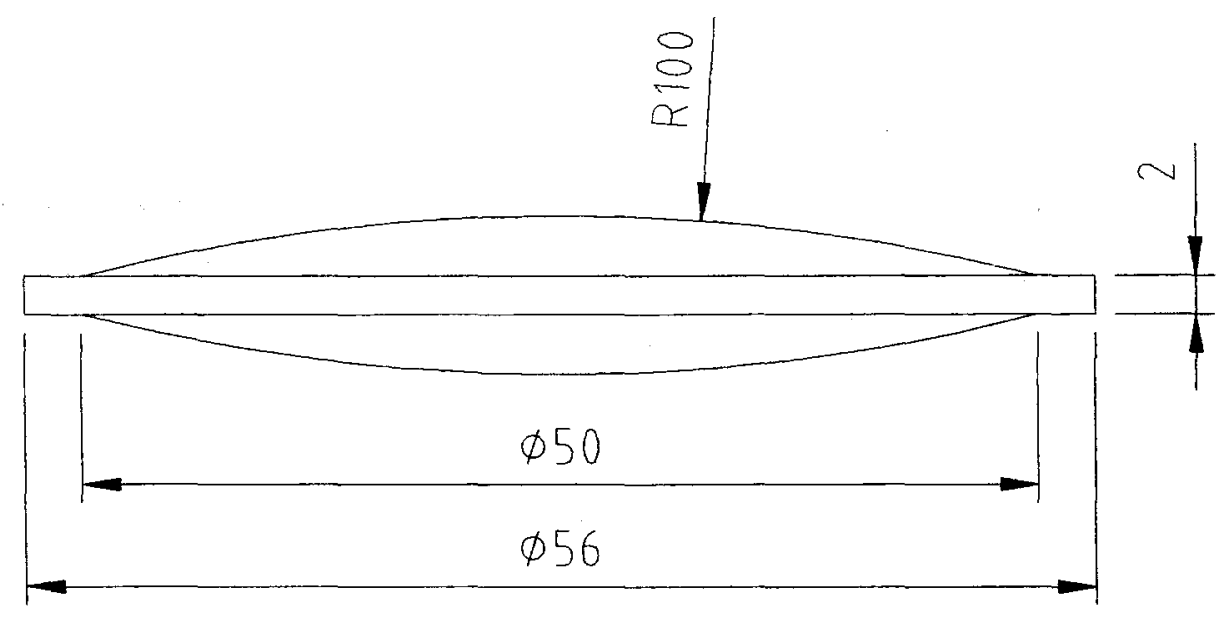

Figura 5.1 - Lente biconvexa de raio $100 \mathrm{~mm}$.

\section{3 - Projeto dos Canais e "Gate"}

Um ponto merecedor de consideração é a grande quantidade de material que deverá fluir para dentro da cavidade. Quando o material flui pelos canais de distribuição do molde, a sua zona mais periférica, que está em contato com as paredes dos canais, resfria-se e solidifica-se. Se o canal não tem um dimensionamento correto, pode resfriar-se totalmente antes que a cavidade esteja preenchida, ou ainda, não estando totalmente solidificado, permitir uma passagem muito estreita em seu núcleo ainda em estado fundido, necessitando de elevadas pressões de injeção ou ocasionando o lento preenchimento da cavidade, algo que não é desejado. Considerando-se a espessura média da lente, projetou-se o canal de distribuição como ilustrado na figura 5.2. Como pode ser visto na mesma figura, o canal de distribuição está localizado totalmente na placa inferior. $O$ tipo de canal que apresenta melhores resultados é o de formato cilíndrico, porém, esse tipo de canal precisa ser usinado en ambas as faces da linha de abertura do molde. Uma forma mais econômica e que também 
apresenta resultados satisfatórios e a forma trapezoidal que possui inscrito em seu interior o diâmetro recomendado pela literatura.

A figura 5.2 ilustra apenas as regiões a serem preenchidas pela resina fundida. No alto da figura tem-se uma vista lateral e abaixo a vista obtida na placa móvel do molde. A entrada de material é o ponto de alimentação do molde. $O$ "gate" é um estreitamento do canal de alimentação tanto na largura quanto na profundidade. As cavidades superior e inferior em conjunto conformam o perfil da lente a ser injetada. As saídas de gases permitem a expulsão do ar durante o preenchimento da cavidade e têm a profundidade de alguns centésimos de milímetro. A seção A-A representa um corte transversal mostrando o perfil do canal de alimentação. $O$ círculo tracejado no interior do canal indica o diâmetro recomendado pela literatura $(D=6 \mathrm{~mm})$.

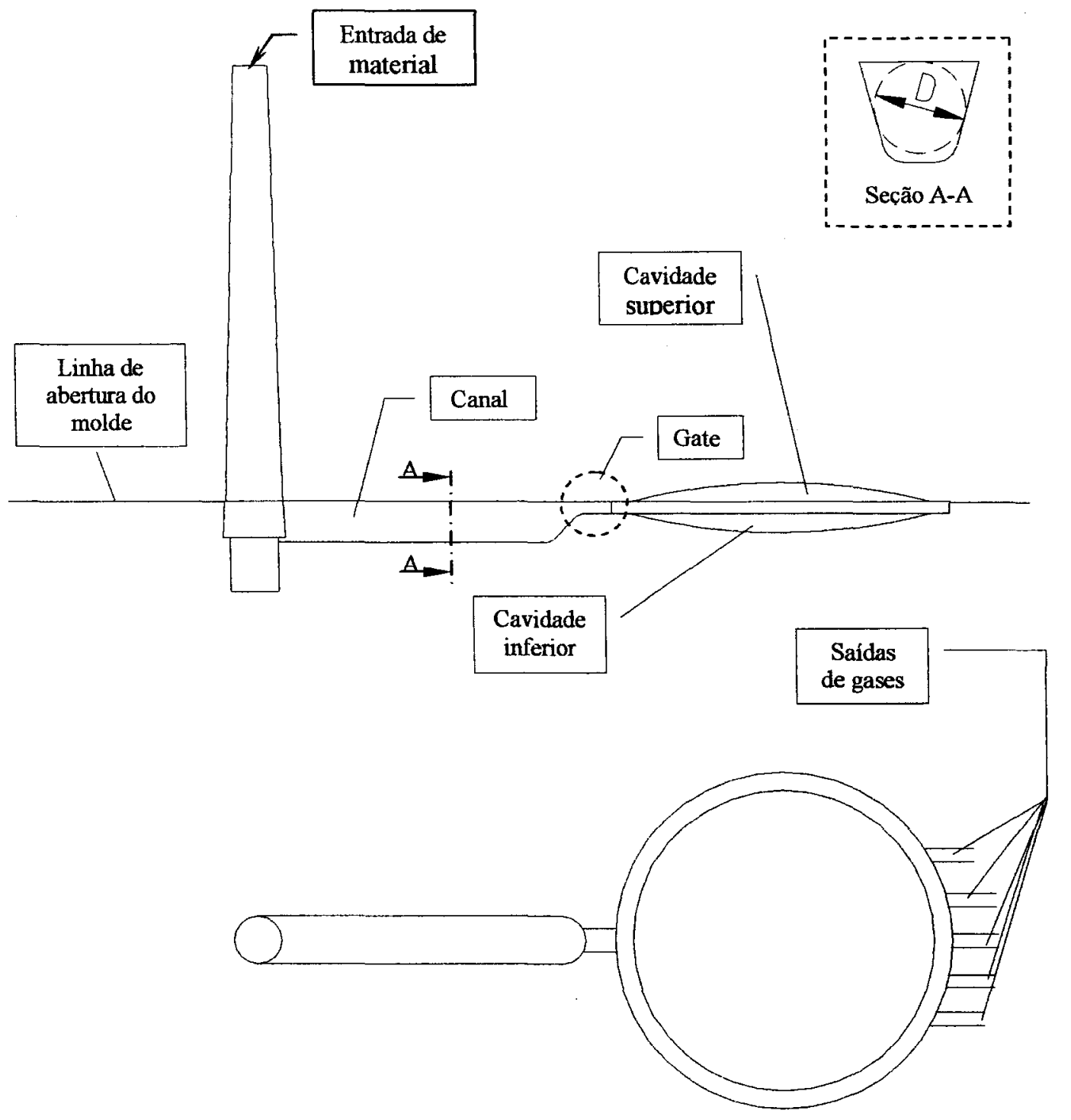

Figura 5.2 - Configuração do sistema de alimentação da cavidade. 


\section{4 - Projeto do Sistema de Refrigeração}

Apesar do controle da temperatura do molde ser importante na produção de componentes plásticos, na maioria dos casos, esse tipo de controle é visto apenas como um dos fatores coadjuvantes para aumentar a velocidade do processo, permitindo altos ciclos de injeção. $O$ que normalmente não é considerado, é que a ineficiência do sistema de refrigeração pode ocasionar a perda de certas caracteristicas fundamentais do componente. Algumas características afetadas são a resistência, o aumento de tensões internas e o acabamento superficial.

De maneira muito resumida pode-se dizer que no processo de resfriamento:

- O fluxo de calor ocorre do corpo com temperatura mais alta para aquele com temperatura mais baixa;

- É a diferença de temperatura que determina o fluxo e não a quantidade de calor presente;

- O resfriamento ou transferência de calor pode ocorrer de três formas: radiação, condução e conveç̧ão.

Para calcular a quantidade de calor que entra no molde a cada ciclo de injeção utiliza-se a equação:

$$
Q=M\left(T_{1}-T_{2}\right) \rho+c
$$

sendo,

$$
\begin{aligned}
Q & =\text { quantidade de calor por hora; } \\
M & =\text { massa de material plástico injetado por hora; } \\
T_{1} & =\text { Temperatura de fusão do plástico; } \\
T_{2} & =\text { Temperatura do plástico durante a abertura do molde; } \\
\rho & =\text { Calor específico do material plástico; } \\
c & =\text { Calor latente de fusão. }
\end{aligned}
$$

No resfriamento de moldes, a forma de transferência de calor que permite maior controle é a transferência por condução. $O$ controle da transferência por condução é realizado fazendo-se circular um líquido refrigerante, normalmente água, por um sistema de dutos. Os fatores que afetam o fluxo de calor por condução são:

- A condutividade de calor do material através de uma distância $L$;

- A área exposta ao fluxo de calor ou a área da cavidade do molde;

- A diferença de temperatura entre o plástico que entra e a temperatura na qual o molde deve permanecer.

A fórmula que se aplica a está condição é:

$$
Q=k A\left(T_{1}-T_{2}\right) / L
$$


sendo,

$Q=$ quantidade de calor por hora;

$k=$ condutividade térmica do material em questão;

$T_{2}=$ temperatura do liquido refrigerante;

$T_{1}=$ temperatura do material fundido;

$A=$ área da cavidade;

$L=$ distância entre a superficie da cavidade e a extremidade superior do duto de refrigeração.

$\mathrm{Na}$ utilização das equações 5.1 e 5.2, o tempo é dado em horas para que o resultado dos cálculos seja mais condizente com a prática, uma vez que durante um ciclo de injeção existem variações na temperatura.

A equação 5.2 não considera a condição real de variação da temperatura com relação ao tempo que resulta em um fluxo de calor não estável. No entanto, segundo Dym (1987) o valor obtido através dessa equação é satisfatório para fins práticos de posicionamento dos dutos de refrigeração no molde.

Aplicando-se os parâmetros projetados para a injeção da lente em acrílico e, considerando-se um ciclo de injeção de $60 \mathrm{~s}$ obtém-se:

$$
\begin{aligned}
& M=1,17 \mathrm{~kg} \text {; } \\
& T_{1}=220^{\circ} \mathrm{C} \text {; } \\
& T_{2}=60{ }^{\circ} \mathrm{C} \text {; } \\
& \rho=1260\left(\mathrm{~J} \cdot \mathrm{Kg}^{-1} \cdot{ }^{\circ} \mathrm{C}^{-1}\right) ; \\
& c=0 \text {. }
\end{aligned}
$$

Portanto,

$$
Q=235872 \mathrm{~J} / \mathrm{h}
$$

,como resultado da eq. 5.1.

Resolvendo a equação 5.2 para $L$ :

$$
L=k A\left(T_{1}-T_{2}\right) / Q
$$

Considerando-se a porção inferior da linha de abertura do molde, tem-se metade da quantidade total de calor a ser dissipada pelo duto de refrigeração inferior. Assim, deve-se tomar $\frac{Q}{2}$ e considerar-se a área superficial da cavidade correspondente a metade inferior do molde. As cavidades do molde foram fabricadas em aço inox e para a eq. 5.2 têm-se finalmente os seguintes parâmetros:

$$
\begin{aligned}
Q & =117936 \mathrm{~J} \cdot \mathrm{h}^{-1} ; \\
k & =61200 \mathrm{~J} \cdot \mathrm{h}^{-1} \cdot \mathrm{m}^{-1} \cdot{ }^{\circ} \mathrm{C}^{-1} ; \\
A & =2,67 \times 10^{-3} \mathrm{~m}^{2} ; \\
T_{1} & =220^{\circ} \mathrm{C} ;
\end{aligned}
$$




$$
T_{2}=70{ }^{\circ} \mathrm{C}
$$

Portanto,

$$
L=0,21 \mathrm{~m}
$$

,como resultado da eq. 5.3

$\mathrm{O}$ resultado da equação 5.3 mostra que um duto posicionado a uma distância de $21 \mathrm{~cm}$ da cavidade do molde resultaria em uma transferência satisfatória de calor para o ciclo desejado para a lente. É claro que, resta ainda, considerar a vazão de liquido refrigerante pelos dutos. Dym (1987) demonstrou que um fluxo turbulento é mais eficaz para o processo de resfriamento do molde do que um fluxo laminar. A diferença entre o fluxo laminar e o turbulento pode ser verificada na figura 5.3.

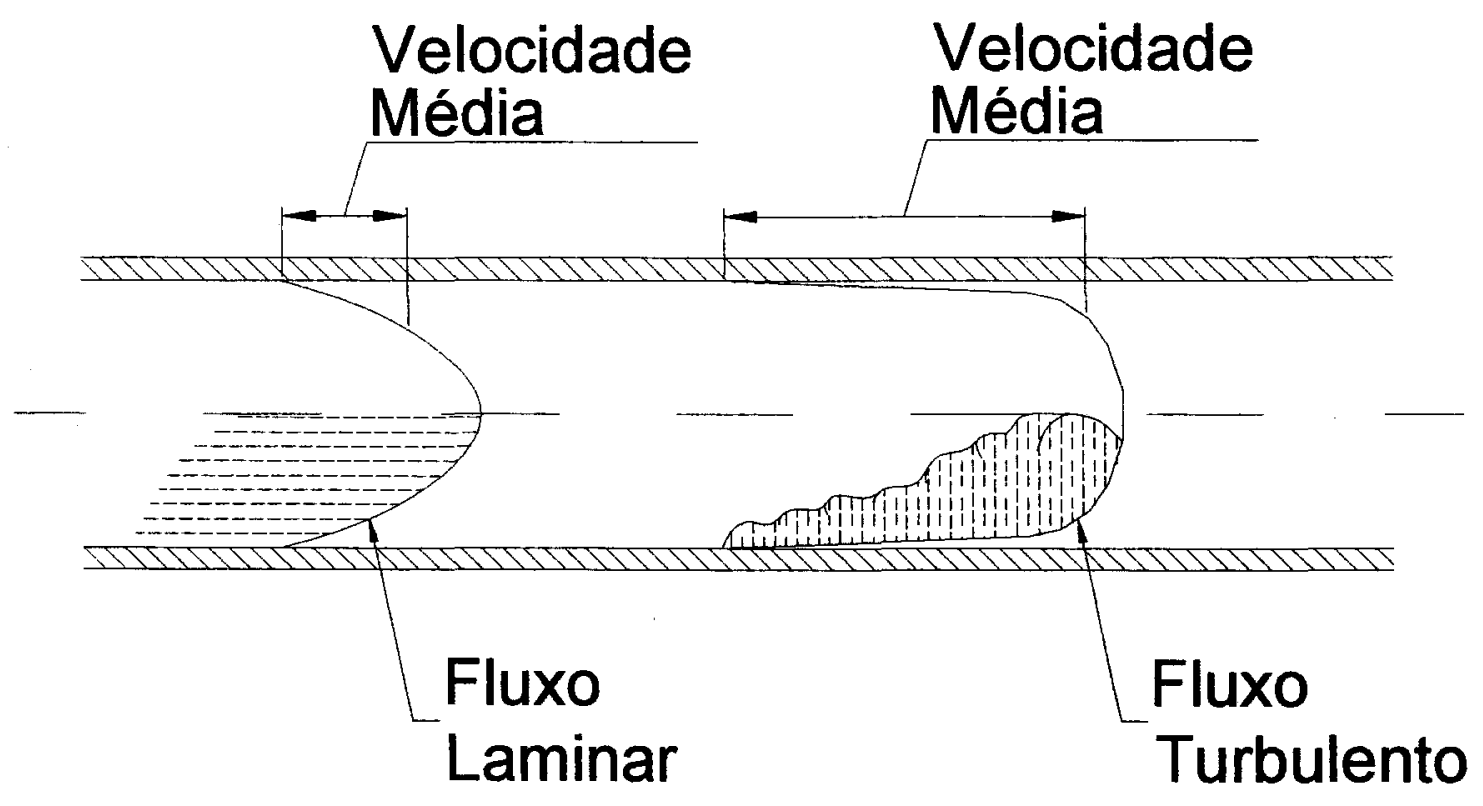

Figura 5.3 - Diferença entre fluxo laminar e turbulento (Dym, 1987)

O fluxo turbulento apresenta uma velocidade média maior do que o fluxo laminar. Esse fato somado à maior dispersão das moléculas de água dentro do duto contribuem para a maior eficiência do fluxo turbulento para o resfriamento.

Para uma vazão de água de 2,1 litros por minutos, foram adotados para o sistema de refrigeração do molde, dutos com diâmetro de aproximadamente $8,5 \mathrm{~mm}$. Esse diâmetro fornece a turbulência necessária para espalhar as moléculas de água contra as paredes do duto.

Uma análise preliminar do produto em conjunto com os resultados da simulação computacional do processo de injeção das lentes demonstra que o centro da lente sofrerá um retardo no resfriamento devido à sua maior espessura. Considerando-se esse problema, os dutos de refrigeração foram posicionados próximos do centro da cavidade, numa tentativa de 
equilibrar o resfriamento da lente, minimizando, assim, os efeitos do resfriamento não uniforme. $\mathrm{O}$ sistema de refrigeração do molde pode ser visualizado nas figuras 5.5 e 5.6. Durante os testes de injeção, as temperaturas observadas com o auxilio dos termopares demonstraram grande estabilidade, sendo possível fixar a temperatura da cavidade em valores próximos à temperatura da água circulante nos dutos. Isso comprova a eficiência do sistema de refrigeração projetado. Deve-se observar que parte do calor é continuamente dissipado para o ambiente através das partes metálicas da máquina injetora e do próprio molde, porém, controlando-se a vazão e a temperatura do liquido refrigerante que circula nos dutos, pode-se regular a temperatura da cavidade de forma a estabilizá-la em condições ideais para o processo.

\section{5 - Construção do Molde}

O porta-moldes modelo 25-30 da empresa Polimold ${ }^{\circledR}$ foi adquirido por ser adequado para as pressões de injeção e geometria da cavidade da lente. Dessa forma, partiu-se desse porta-moldes para projetar os itens que faltavam para o correto funcionamento do molde. Os desenhos do molde foram realizados com todos os detalhes necessários à sua construção.

Para a confecção das cavidades, definiu-se como material adequado à aplicação o aço inoxidável SAE 304, por apresentar resistência à oxidação, facilidade de usinagem e acabamento final adequado à produção de lentes. Como detalhe adicional, em relação a um molde convencional utilizado na indústria, foram instalados dois termopares próximos às cavidades superior e inferior para monitoramento da temperatura durante a injeção. Os perfis das cavidades e do polidor de ferro fundido nodular foram confeccionados em um torno com controle numérico computadorizado com o raio de $100 \mathrm{~mm}$. $O$ polimento das cavidades foi realizado manualmente com o polidor e pasta abrasiva, com os insertos rotacionados em uma politriz.

A figura 5.4 apresenta uma fotografia do molde desmontado, mostrando alguns de seus componentes internos. Um corte longitudinal da montagem do molde poder ser visto na figura 5.5, onde a região preenchida na cor verde corresponde aos canais, "gate" e cavidade.

Na figura 5.6, os insertos superior e inferior em conjunto conformam a lente a ser moldada. No inserto inferior observa-se a proximidade do duto de refrigeração da cavidade para minimizar as diferenças de resfriamento da cavidade. $O$ furo de pequeno diâmetro que aparece sobre a cavidade no inserto superior foi utilizado para a colocação de um sensor de temperatura. Na porção inferior do molde, devido à presença dos dutos de refrigeração, o sensor foi colocado ao lado da cavidade e não aparece nessa seção. 


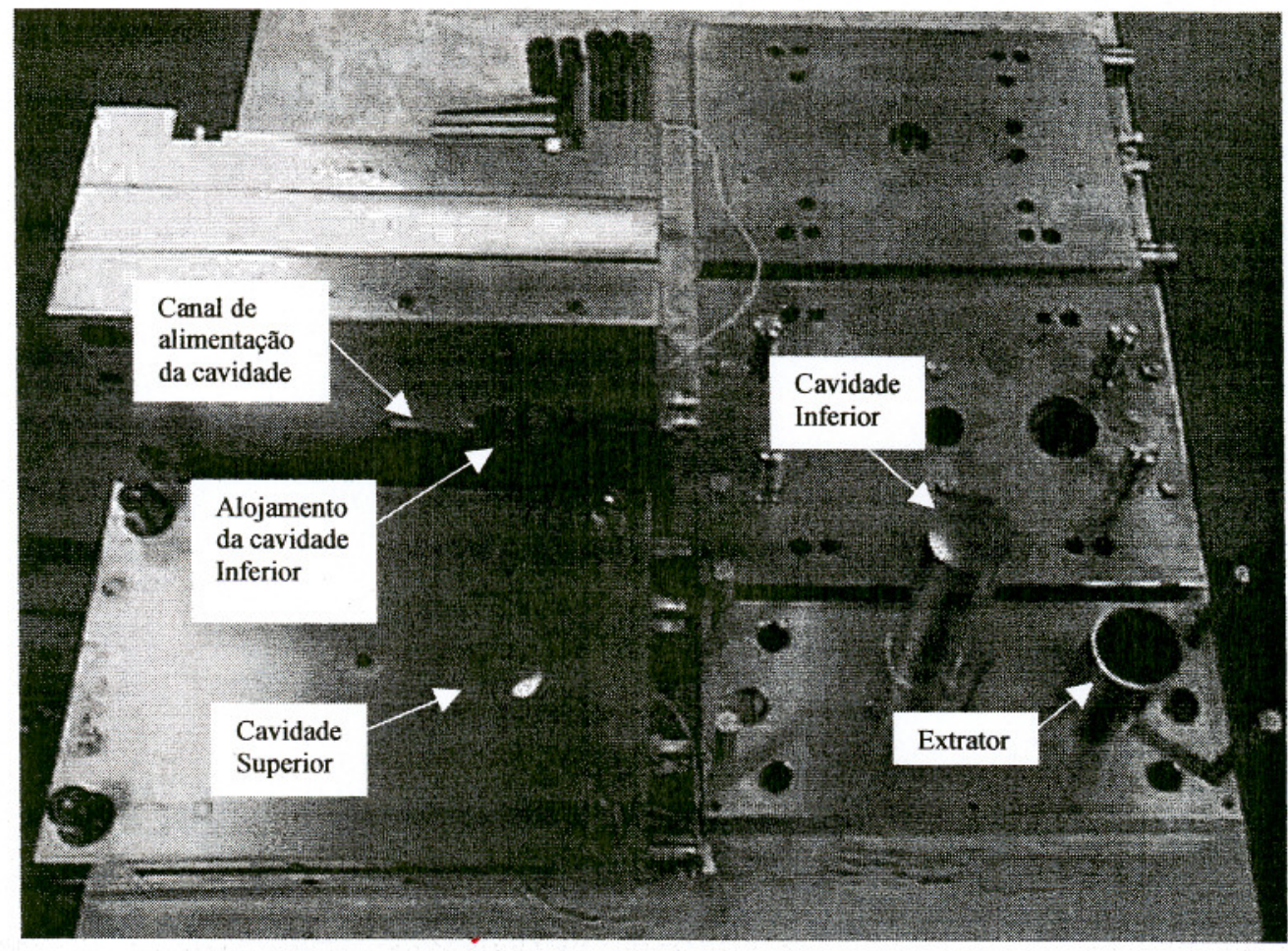

Figura 5.4 - Molde para injetar lentes acrílicas desmontado

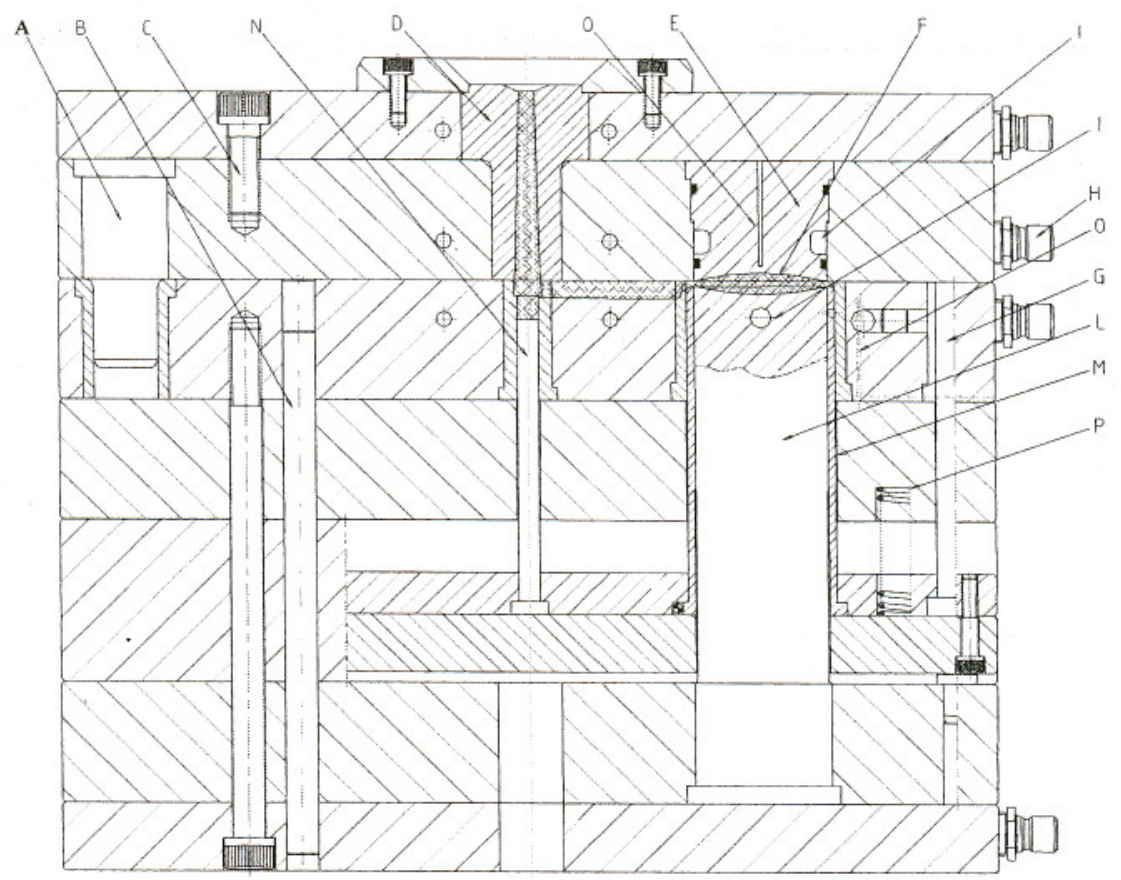

\section{Legenda:}

A - coluna de alinhamento, B - pino de travamento, C - parafuso,

$\mathrm{D}$ - bucha de entrada, $\mathrm{E}$ - inserto $1, \mathrm{~F}$ - cavidade,

$\mathrm{G}$ - pino de retorno do extrator, $\mathrm{H}$ - engate para refrigeração,

$\mathrm{I}$ - duto de refrigeração, $\mathrm{J}$ - extrator do canal, $\mathrm{L}$ - inserto 2,

$\mathrm{M}$ - extrator da lente, $\mathrm{N}$ - extrator do canal,

$\mathrm{O}$ - termonar. $\mathrm{P}$ - mola de retorno do extrator

Figura 5.5 - Montagem do Molde - seção longitudinal 


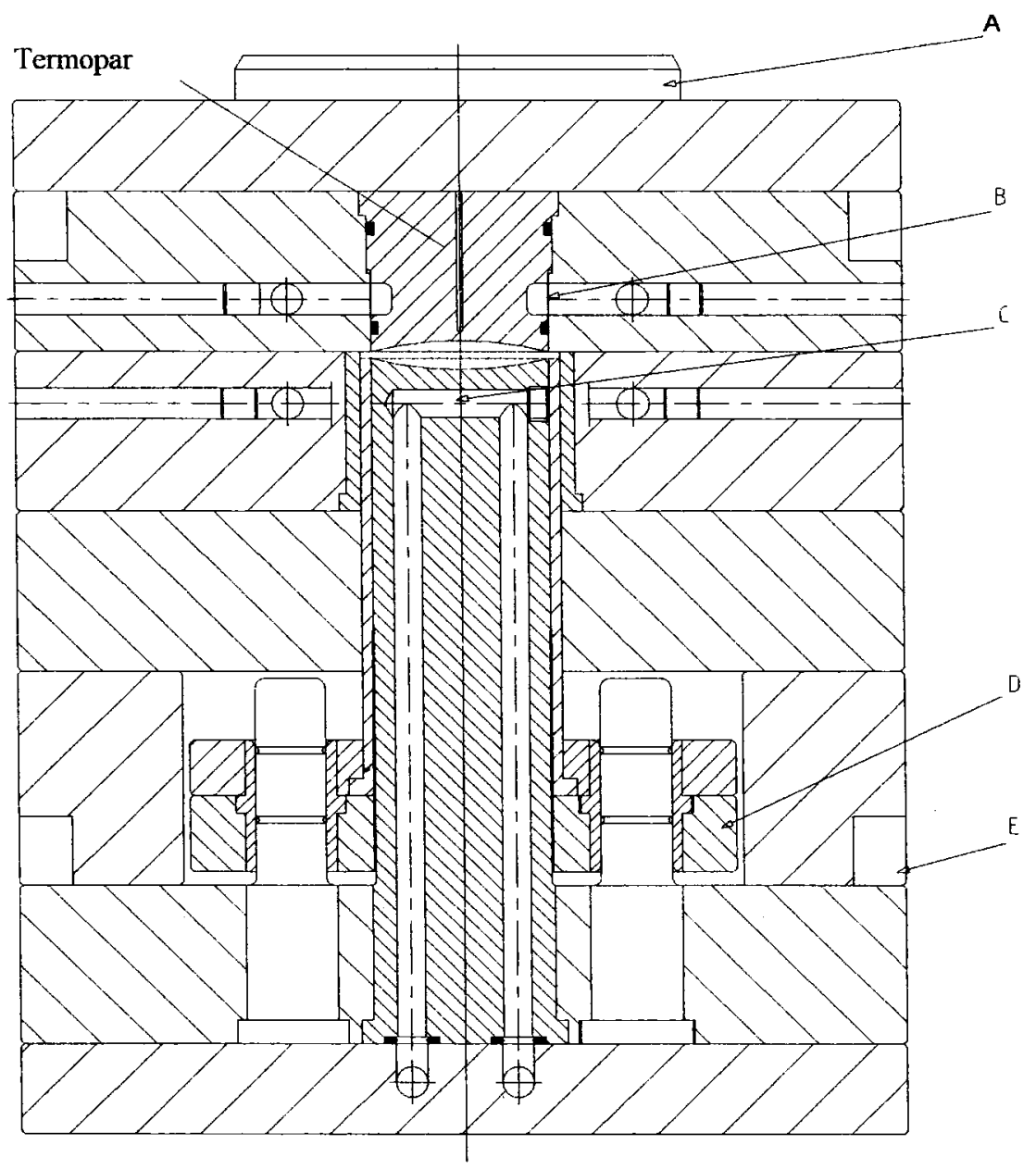

\section{Legenda:}

A - flange de centragem, $\mathrm{C}$ - duto envolvendo o inserto 1 , $\mathrm{C}$ - duto interno no inserto $2, \mathrm{D}$ - placa porta-extratores, $\mathrm{E}$ - rebaixo para fixação do molde na injetora.

Figura 5.6 - Montagem do Molde - seção tranversal 


\section{6 - TESTES DE INJEÇÃO E RESULTADOS}

\section{1 - Introdução}

O objetivo desse capitulo é apresentar os testes de injeção das lentes e está dividido em duas seções; a primeira traz uma breve descrição dos recursos utilizados para a realização dos testes e a segunda apresenta a sistemática utilizada juntamente com alguns resultados oriundos da observação direta do processo de injeção e das lentes obtidas.

É oportuno dizer que o processo de injeção de elementos com um nível de qualidade como aquele desejado para lentes implica a existência de equipamentos (molde e injetora) em excelente estado de conservação, de forma a permitir alta repetitibilidade do processo de ciclo a ciclo. Além dessa necessidade, é importante um ambiente de trabalho limpo, com níveis de temperatura e umidade controlados e de materiais para injeção que seguramente apresentem sempre a mesma composição. Caso esses itens não sejam observados, o que se tem é uma variação do processo que pode inviabilizar a produção de elementos ópticos.

\section{2 - Recursos Utilizados}

Para os testes de injeção, utilizou-se de uma injetora da marca ROMI ${ }^{\circledR}$ modelo PRIMAX 100R - CONTROLMASTER 8 com a unidade de injeção modelo 236, que possui parafuso plastificador com diâmetro de $40 \mathrm{~mm}$. Essa injetora possibilita a injeção de peças, que em conjunto com os canais de distribuição, tenham o volume máximo de $175 \mathrm{~cm}^{3}$. $O$ tamanho mínimo permitido para o molde é $270 \times 270 \times 150$ (largura $\times$ comprimento $\mathrm{x}$ altura - mm) enquanto que o máximo é $640 \times 410 \times 410$. O curso máximo de abertura é de $410 \mathrm{~mm}$ e a força de fechamento é de 100 TON. Uma fotografia da injetora pode ser vista na figura 6.1 .

Para a injeção de acrilico, é necessário que o molde seja aquecido a uma temperatura entre 50 e $90{ }^{\circ} \mathrm{C}$. Isso foi realizado, fazendo-se circular água aquecida pelos dutos de refrigeração. A temperatura foi continuamente monitorada pelos termopares instalados no molde. $\mathrm{O}$ aquecimento da água foi obtido através de uma unidade de aquecimento de água agregada a uma bomba. 0 acrílico, o policarbonato e o poliestireno são materiais higroscópicos que necessitam de secagem prévia antes de serem utilizados para alimentar o funil da máquina injetora. A secagem dos materiais foi realizada através de uma estufa, à temperatura controlada de acordo com a necessidade de cada material. 


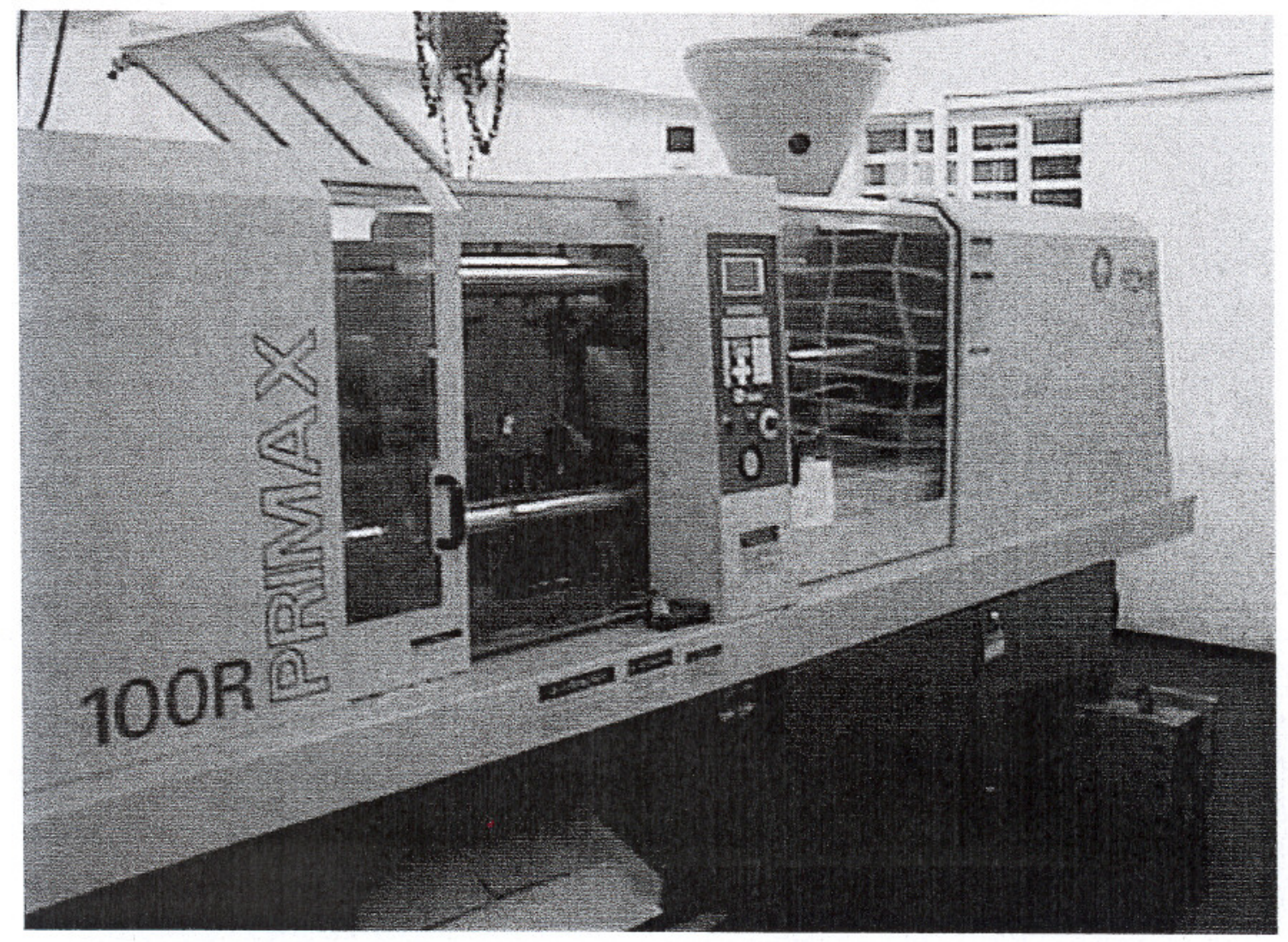

Figura 6.1 - Injetora PRIMAX 100R

\section{3 - Testes de Injeção}

Nos testes de injeção do acrílico e do poliestireno, os materiais foram colocados previamente na estufa a uma temperatura entre 80 e $90{ }^{\circ} \mathrm{C}$, por um período de 2 horas. Para o policarbonato a temperatura de secagem foi de $120^{\circ} \mathrm{C}$, por um período de 4 horas.

A fase de testes de injeção das lentes foi iniciada, utilizando-se o poliestireno que é de baixo custo.

Após alguns ajustes iniciais nos parâmetros da máquina injetora, obteve-se a injeção de lentes que apresentaram características muito satisfatórias para a fase de testes do molde. Verificou-se que a maior dificuldade prevista, que seria a acentuada deformação da superfície esférica da lente durante o resfriamento, mostrava-se possível de ser contornada. Já nessa fase inicial, pode-se perceber a necessidade de ajustes nas dimensões do "gate" para melhorar o processo de injeção. As alterações realizadas foram a aproximação do canal de alimentação da cavidade e também o aumento da seção do "gate". Esse por sua vez, foi usinado em um ângulo de $45^{\circ}$ em relação ao plano de abertura do molde de forma a direcionar o fluxo contra a cavidade superior, evitando-se, assim, o efeito de jateamento que poderia provocar manchas na lente. Essas alterações são apresentadas na figura 6.2. 


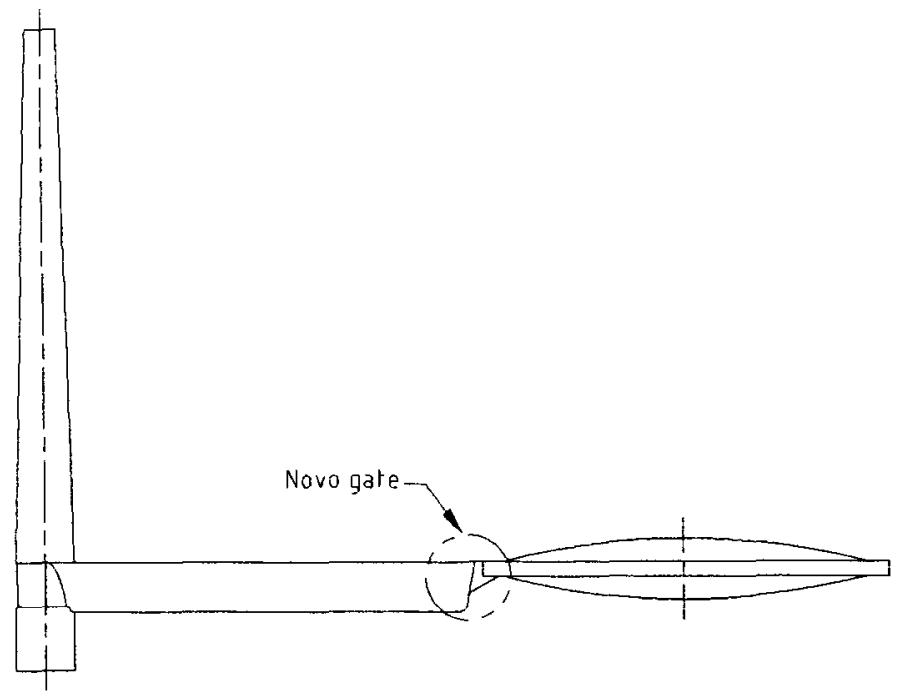

Figura 6.2 - Lente e canais com novo "gate"

A alteração realizada não afeta de forma significativa os resultados obtidos pela simulação numérica descritos no item 4.3. De fato, somente as propriedades mecânicas relacionadas com o perfil da superficie são afetadas.

Após as alterações no molde, foram realizados testes com o acrilico e poliestireno. Foram inúmeros testes, com os mais diversos parâmetros. Esses testes foram nomeados de "A" a " $Z$ ", enquanto que os testes com policarbonato realizados a seguir foram identificados pela sigla "PC" seguida do número seqüencial do teste. Os parâmetros utilizados nos testes de maior relevância podem ser verificados na tabela 6.2 .

Nos testes K e M foi utilizado o poliestireno EDN da empresa "Poliestireno do Sul". Os testes A, B, C e G foram realizados com acrílico 01-DE-LE, os testes $\mathrm{S}$ e $\mathrm{T}$ foram realizados com o acrílico 01-H-ECL enquanto que nos testes $\mathrm{X}$ e $\mathrm{Z}$ utilizou-se o acrílico 01DH-ECL-P todos da empresa Metacril. O fabricante destaca o acrílico 01-DH-ECL-P como o que apresenta melhores propriedades ópticas devido ao controle de qualidade mais apurado. A tabela 6.1 apresenta características dos materiais fornecidas pelo fabricante.

Tabela 6.1 - Características técnicas do acrilico Acrigel@ (Metacril)

\begin{tabular}{|l|c|c|c|c|c|}
\hline \multirow{2}{*}{ Característica } & \multirow{2}{*}{ Métodos } & \multirow{2}{*}{ Un. } & \multicolumn{3}{|c|}{ Material } \\
\cline { 4 - 6 } & & & 01-DH-LE & 01-DH-ECL & 01-DH-ECL-P \\
\hline Fluidez & ASTM D-1238 & $\left(\mathrm{g} / 10^{\prime}\right)$ & $4,0-6,0$ & $1,2-3,0$ & $1,2-3,0$ \\
Densidade & ASTM D-0792 & $(\%)$ & $1,17-1,19$ & $1,17-1,19$ & $1,17-1,19$ \\
Contração & ASTM D-0955 & $\left(\mathrm{g} / \mathrm{cm}^{3}\right)$ & $0,4-0,6$ & $0,4-0,6$ & $0,4-0,6$ \\
Transmitância & ASTM D-1003 & $(\%)$ & min. 90 & min. 90 & min. 90 \\
\hline
\end{tabular}

Na tabela 6.2 os itens velocidade e contra-pressão da etapa de plastificação referemse à velocidade de rotação do parafuso plastificador e à pressão exercida pelo mesmo sobre a massa fundida. $\mathrm{Na}$ fase de recalque, uma pressão pré-determinada é exercida sobre o plástico, forçando a entrada de material adicional que compensa a contração do material. 
Os valores presentes no item resultado estão relacionados com o aspecto visual da lente que deve se apresentar livre de manchas, bolhas e marcas de fluxo. Os valores foram atribuídos segundo o critério abaixo:

1 - alta deformação da superficie e da imagem obtida através da lente;

2 - presença de bolhas e deformação pouco menor que a do índice 1 ;

3 - presença de bolhas em menor número e deformação menor que do índice 1;

4 - ausência de bolhas e deformação semelhante à do índice 2;

5 - ausência de bolhas e deformação quase imperceptivel a olho nu.

A pressão de recalque e a pressão de injeção mostraram-se determinantes na obtenção de lentes com qualidade por influirem diretamente no nível de deformação das lentes. Outro aspecto que merece consideração no processo de injeção é a presença de umidade no material. Observou-se que, quando o material foi colocado sem a secagem prévia, ocorreu o surgimento indesejável e inevitável de bolhas no produto injetado. Com o material devidamente seco, as bolhas também ocorreram mas, com o aumento da velocidade de rotação do parafuso e da contra-pressão pôde-se encontrar o ajuste ideal, que permitiu a expulsão das bolhas no cilindro durante a fase de plastificação, resultando em um produto com boa qualidade. Deve-se observar que o aumento excessivo da velocidade do parafuso fez surgir inclusões no produto injetado.

$\mathrm{O}$ corte e análise de algumas lentes permitiram constatar que as inclusões eram porções do material que entraram na cavidade sem estarem totalmente fundidas. Assim, conclui-se que na etapa de plastificação deve-se encontrar o ajuste ideal que permita a total homogeneização do material, ao mesmo tempo que propicie a expulsão total dos gases gerados durante o processo. A utilização do policarbonato mostrou-se ineficiente para aplicação desejada e com os recursos disponíveis, resultando em lentes com alto nível de deformação mesmo com as mais altas pressões de injeção e de recalque permitidas pela máquina injetora.

Ainda em relação aos testes de injeção, observou-se que o processo é otimizado quando ocorre de forma cíclica, sem interrupções. Na verdade, quando é necessário interromper o processo por qualquer motivo, a sua retomada implica a perda inicial de duas ou três lentes. Isso se deve provavelmente à degradação que ocorre com a resina fundida no cilindro da máquina injetora ou no bico de injeção. Dependendo do tempo de paralisação do processo, pode-se ter lentes com inclusões de cor escura ou a presença de bolha ou microbolhas. Afastando-se o cilindro de injeção do molde, pôde-se observar o material purgando continuamente através do bico, impulsionado pelos gases gerados no interior do cilindro e que são a origem das bolhas. Já as inclusões escuras, são porções degradadas do material devido à sua permanência por tempo excessivamente longo em zonas do cilindro ou do bico com alta temperatura. 
Tabela 6.2 - Parâmetros de processo utilizados nos principais testes de injeção

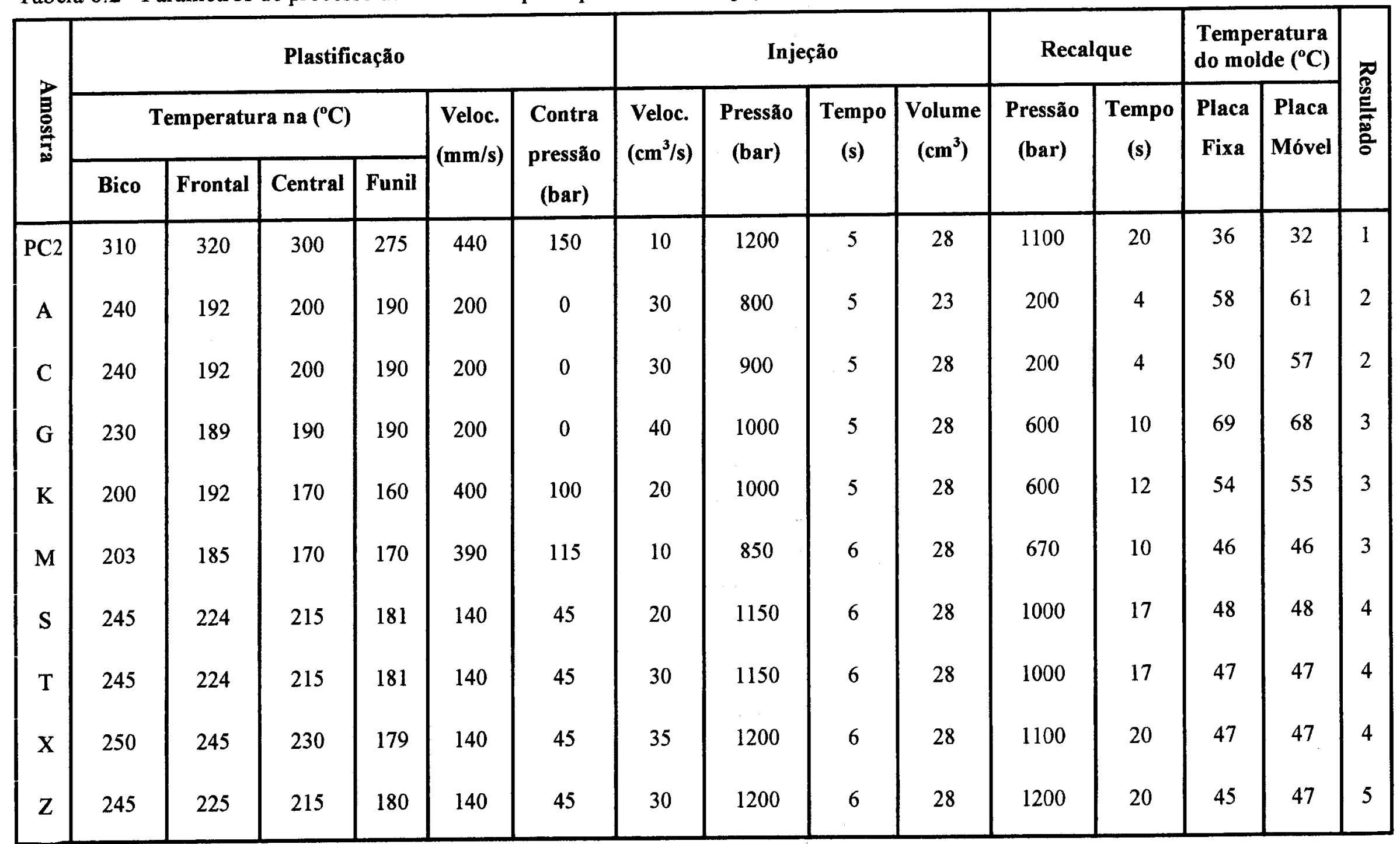


Outro aspecto a ser considerado, é a presença de "fios" originários da separação do material solidificado no canal de entrada do molde, daquele ainda fundido na saída do bico, no final de um ciclo completo. Esses "fios" são empurrados para dentro da cavidade no ciclo seguinte e provocam o surgimento de marcas que inutilizam o produto. $\mathbf{O}$ controle desse efeito indesejável foi realizado com a alteração da temperatura do bico, que se situou entre 245 e 250 ${ }^{\circ} \mathrm{C}$. Se a temperatura for menor, o "fio" aparece e se for maior, a deformação na superficie da lente aumenta. Isso demonstra que o ajuste da máquina se tornou muito crítico, o que não é desejável. Uma forma de solucionar esse problema seria dotar o molde ou a máquina com um tipo de bico que possua uma válvula que feche a passagem de material ao final de cada ciclo, eliminando assim o "fio". Com isso, temperaturas diferentes seriam testadas e poder-se-ia ter melhores resultados. Esse tipo de bico existe comercialmente, porém, a sua utilização implica custos adicionais e alterações no molde existente.

Com relação à lubrificação das partes móveis do molde, principalmente dos extratores, é preciso atentar para a escolha correta de um lubrificante que se mantenha sólido mesmo com a elevação da temperatura. Se o lubrificante não tem a viscosidade adequada, ele pode impregnar a cavidade ou canais do molde e assim alterar a qualidade das lentes.

Nesse momento, é preciso dizer que o acabamento da cavidade não foi satisfatório para a aplicação. Na fase final de polimento, descobriu-se que o material utilizado apresentava imperfeições em sua constituição. Essas imperfeições manifestaram-se como micro-crateras que prejudicaram o acabamento superficial da lente. Esse fato, apesar de indesejável, foi ignorado para que os trabalhos pudessem prosseguir. A correção dessas imperfeições resumese na confecção de duas novas cavidades com material e polimento adequados; dessa forma, os resultados obtidos nos testes, no que se refere à deformação da superficie que é o principal problema, não são alterados.

A figura 6.3 apresenta uma imagem do molde na máquina durante o processo de injeção, na fase de extração, enquanto que a figura 6.4 apresenta uma das lentes obtidas. 


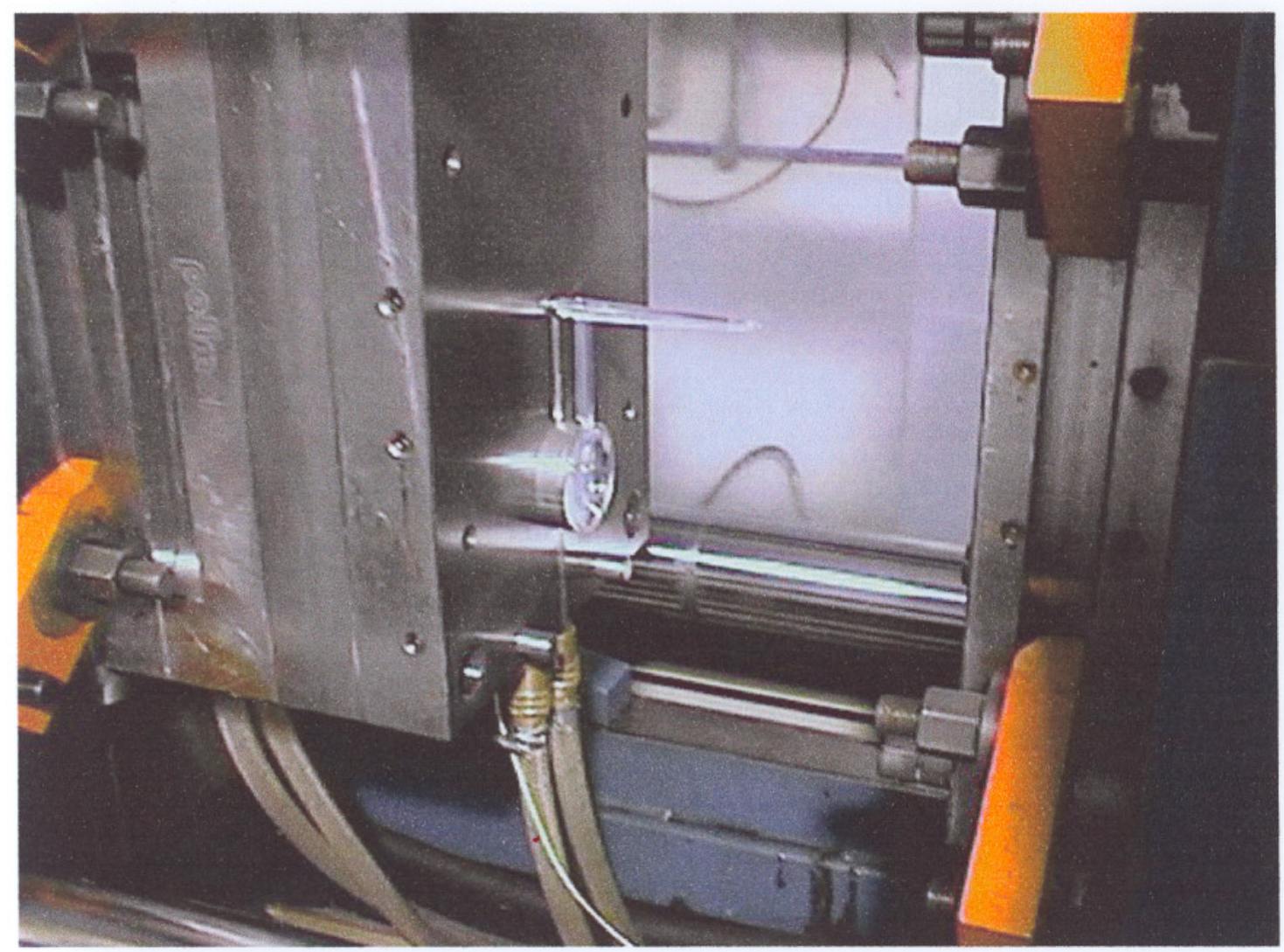

Figura 6.3 - Molde na injetora durante a fase de extração.

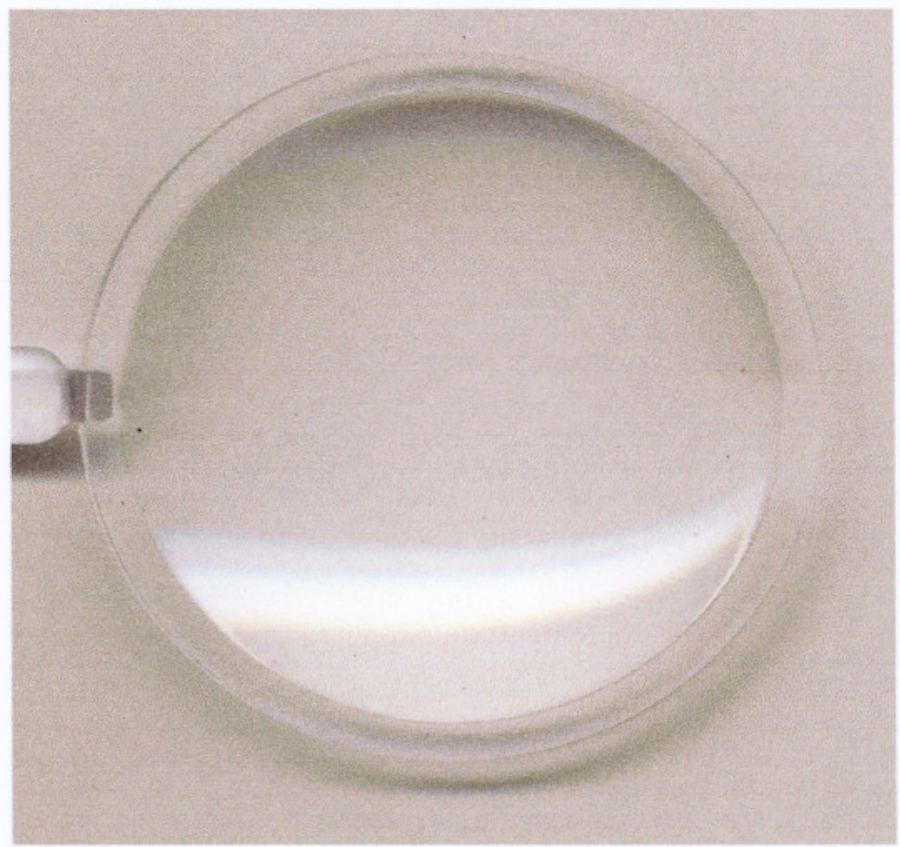

Figura 6.4 - Fotografia da lente injetada. 


\section{7 - CARACTERIZAÇÃO DAS LENTES}

\section{1 - Introdução}

A caracterização das lentes injetadas foi realizada através de diversas técnicas. 0 objetivo foi estabelecer parâmetros que permitissem ao mesmo tempo, verificar a qualidade das lentes obtidas e também fornecer dados que servissem de referência para futuros trabalhos que abordassem esse processo de fabricação de lentes. Como citado no item 6.3 , a utilização do policarbonato não produziu resultados satisfatórios e dessa forma, algumas medidas não foram realizadas com lentes injetadas com esse material.

Com os objetivos descritos acima, o item 7.2 apresenta o resultado das medidas de transparência e o item 7.3 a medida do índice de refração. Com essas medidas, procura-se verificar se o processo de injeção altera as características ópticas das mesmas. No item 7.4 , as tensões das lentes são analisadas através da observação da birrefrigência induzida e do resultado de tratamentos para alívio de tensões. $O$ item 7.5 traz a avaliação da qualidade óptica das lentes através de medidas de FTM, além de uma breve explanação dos conceitos envolvidos nesse tipo de medida. No item 7.6, é apresentado o resultado da medida da distância focal.

Finalmente, nos itens 7.7 e 7.8 são apresentados os resultados da análise da deformação das lentes injetadas; acredita-se que essas duas últimas medidas são as mais relevantes para trabalhos futuros que contemplem melhorias para o processo. $O$ item 7.7 traz os resultados de comparações com o perfil projetado e o perfil obtido para as cavidades e lentes, enquanto que, no item 7.8 mede-se a planicidade de anéis concêntricos igualmente espaçados através das superficies de ambos os lados da lente.

\section{2 - Transmitância}

As lentes injetadas foram analisadas num espectrofotômetro CARY 17 (VARIAN). Observou-se, como era esperado, que as lentes em acrílico apresentam indice de transmitância superior à das lentes em poliestireno. As curvas de transmitância das lentes injetadas em acrílico, em poliestireno, em policarbonato e do acrilico polimerizado podem ser observadas na figura 7.1. A transmitância das lentes injetadas em acrílico apresenta curva similar à do acrílico polimerizado, demonstrando que a forma como foi conduzido o processo de injeção não alterou as características intrínsecas do material, que se relacionam com essa propriedade.

Apesar das medidas de transmitância das lentes de poliestireno e policarbonato estarem dentro dos valores esperados, na análise visual, essas lentes não apresentam o mesmo aspecto cristalino apresentado pelas lentes de acrílico. 


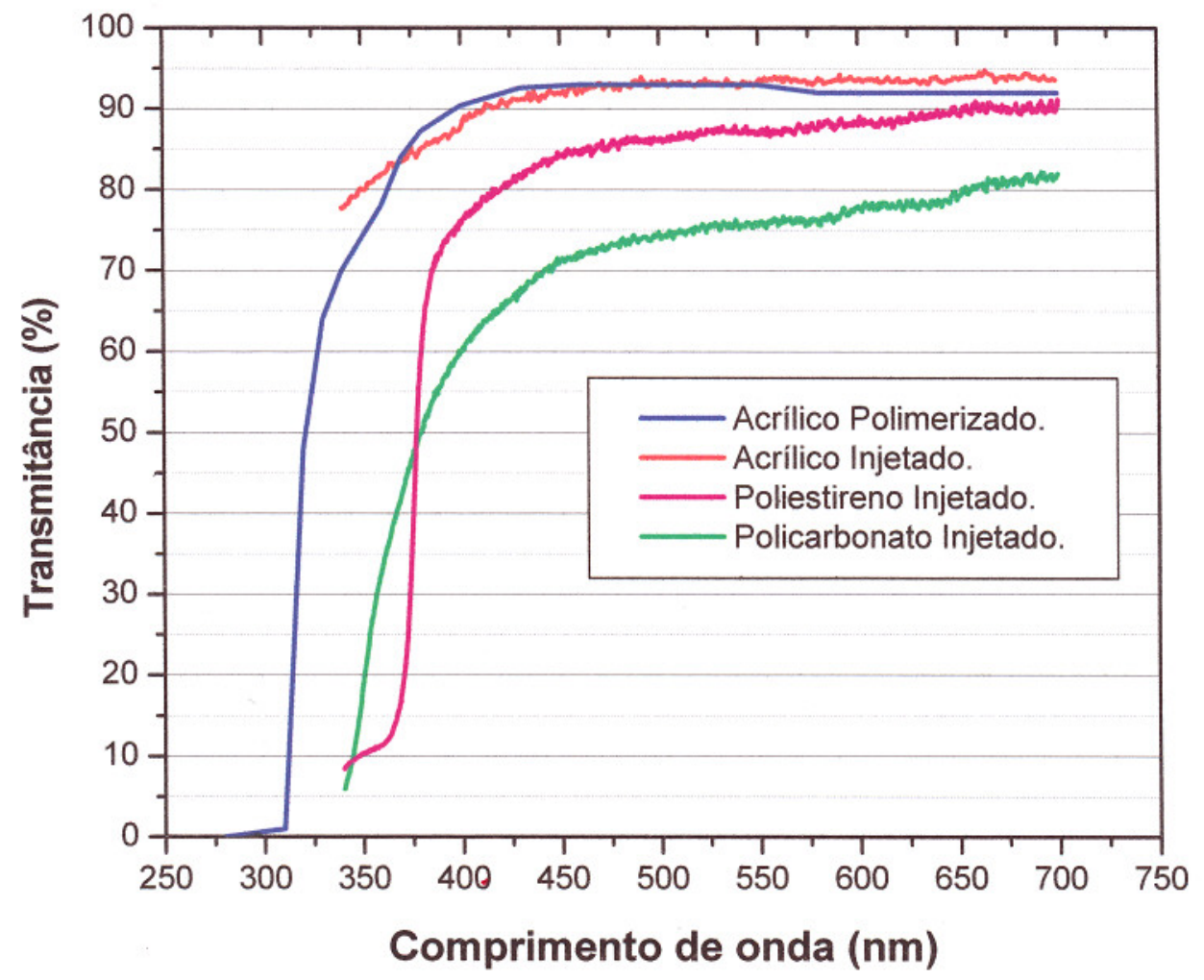

Figura 7.1 - Representação gráfica da transmitância das lentes injetadas.

\section{3 - Medida do Índice de Refração}

As medidas do índice de refração foram realizadas na estação PRISMEN V0 F5 da CARLZEISS, onde se utilizou luz com comprimento de onda de 589,3 nm. Comprimentos de onda de 486,1 e 656,3 nm não foram utilizados por não apresentarem uma resolução adequada para medida do índice de refração das amostras.

Para lentes em poliestireno, o índice médio de refração obtido foi de 1,589 enquanto que para as lentes em acrílico, o índice médio obtido foi de 1,493.

O valor encontrado na literatura para o índice de refração no comprimento de onda utilizado é de 1,489 para o acrílico e de 1,584 para o poliestireno, demonstrando que existe uma pequena diferença com relação aos valores encontrados. Essa diferença deve-se provavelmente ao material utilizado ou foi ocasionada por falhas na confecção dos corpos de prova pois, como se observou, o índice de refração para todas as amostras obtidas com os mais variados parâmetros de injeção varia apenas na $4^{\mathrm{a}}$ casa decimal e não existe um padrão nessa variação, que possa sugerir que alterações nos parâmetros de injeção afetem o resultado.

Um dos objetivos da medida do índice de refração era realizar um estudo do valor desse índice em função dos parâmetros de injeção (temperatura, pressão etc.). Para tal estudo, 
foram feitos, a partir das lentes, corpos de prova conforme especificado pelo fabricante do equipamento (com faces polidas e perpendiculares entre si, com dimensões de $5 \times 5 \mathrm{~mm}$ ).

A conclusão, que se obteve desse estudo, é que o índice de refração do acrílico e do poliestireno não apresenta variações significativas dentro dos parâmetros de injeção utilizados que afetem qualquer utilização das lentes na aplicação proposta. Como os corpos de prova foram confeccionados a partir de regiões diferentes das lentes, pôde-se constatar que elas apresentam índice de refração homogêneo em toda a sua extensão.

\section{4 - Birrefrigência e Tratamento Térmico para Alívio de Tensões}

A birrefrigência é o fenômeno exibido por alguns materiais isotrópicos transparentes que se tornam duplamente refrativos. No caso de plásticos ópticos, isso ocorre quando eles são submetidos a forças externas como compressão ou tração, por exemplo. Ao se observar esses materiais com luz branca polarizada, um padrão de franjas aparece como uma série de continuas e sucessivas faixas de diferentes cores. Cada uma dessas faixas representa um diferente grau de birrefrigência.

Ao se tratar termicamente os materiais citados, ocorre relaxamento das tensões internas. Isso pode ser constatado pelo desaparecimento do padrão de franjas acompanhado da deformação do material. Algumas das lentes injetadas foram tratadas durante períodos aproximados de 1 hora, a temperaturas de cerca de $110^{\circ} \mathrm{C}$.

Observou-se que a variação dos parâmetros de temperatura e pressão dentro do range necessário para a injeção de lentes com o mínimo de qualidade não ocasiona alteração significativa no nível de birrefrigência, uma vez que o padrão observado é praticamente o mesmo para todo o conjunto de lentes da tabela 6.2. Dessa forma, as amostras apresentadas nas figuras 7.2 e 7.3 refletem o resultado geral obtido para os materiais testados.

Com a utilização de dois polarizadores sobrepostos a $90^{\circ}$ e colocado entre uma fonte colimada de luz branca e a lente em teste, verificou-se a presença de tensões internas nas lentes injetadas. Na figura 7.2A, verifica-se que a lente injetada em acrílico apresenta reduzida birrefrigência que se manifesta mais intensamente na região do "gate", deixando dessa forma a região útil da lente em boas condições para a utilização proposta. O tratamento térmico aplicado às lentes de acrílico acabam por inutilizá-las como pode ser visto na figura $7.2 \mathrm{~B}$; em contrapartida, observa-se a melhora do nível de birrefrigência. É evidente a alta concentração de tensões na região do "gate", que sofre grande deformação com o tratamento térmico.

Diferentemente das lentes injetadas em acrílico, as lentes de poliestireno e de policarbonato apresentam um alto nível de birrefrigência que se estende por toda a lente. A birrefrigência dessas lentes pode ser visualizada na figura 7.3. 


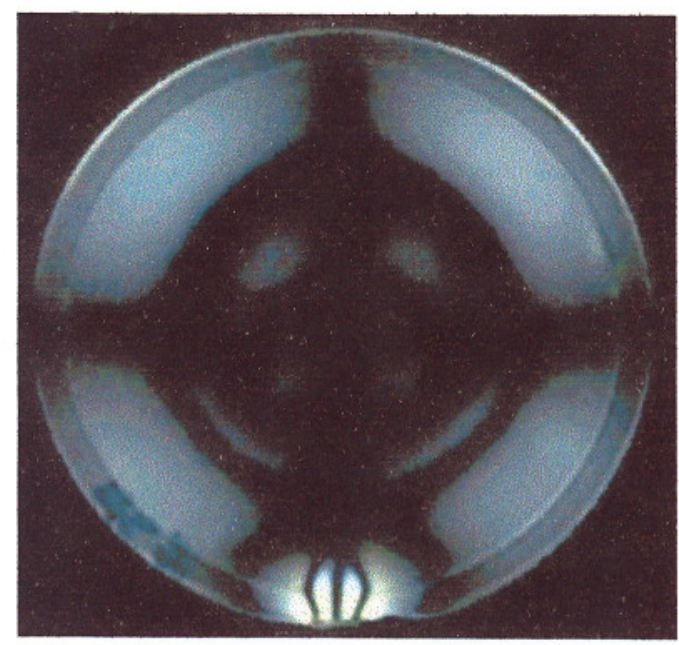

(A)

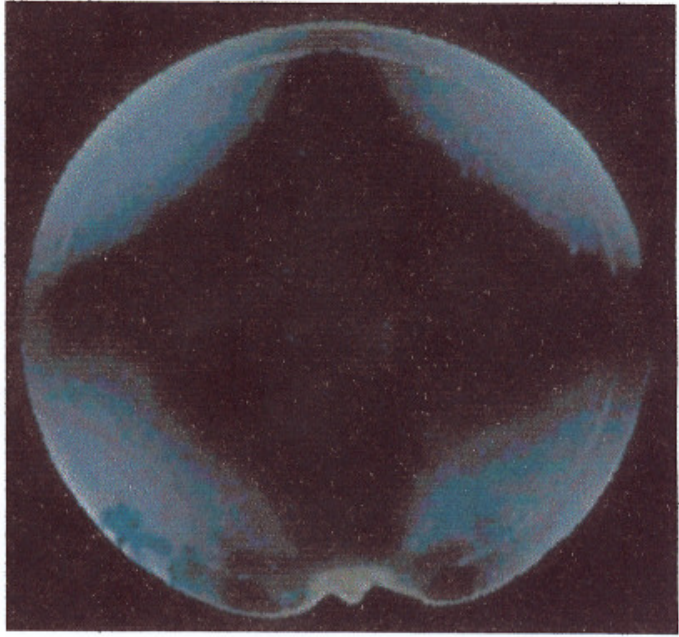

(B)

Figura 7.2 - Avaliação de birrefrigência da lente de acrílico - (A) sem tratamento e (B) com tratamento térmico.

$\mathrm{Na}$ figura 7.3A, é apresentada a birrefrigência de uma lente de policarbonato. A alta temperatura necessária para minimizar os efeitos da contração do policarbonato exige que se utilizem pressões de injeção elevadas ocasionando o alto nível de tensionamento interno observado. Por outro lado, pode ser visto na figura 7.3B que as lentes injetadas em poliestireno apresentam padrão de birrefrigência mais uniforme mas, mesmo assim, com perda de qualidade óptica, quando comparadas com as lentes de acrílico.

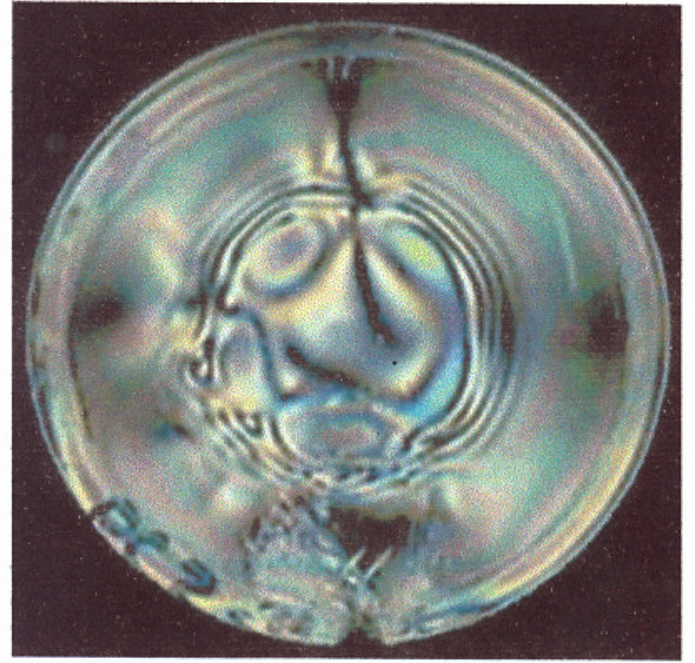

(A)

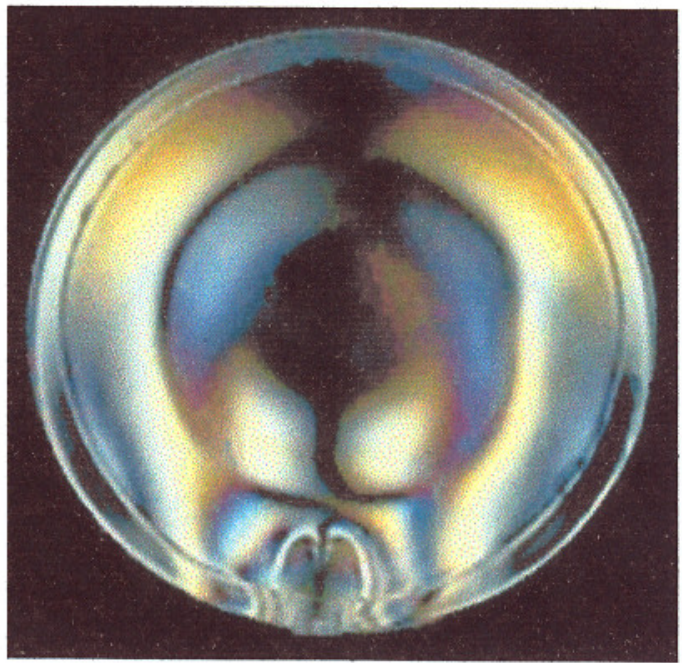

(B)

Figura 7.3 - Birrefrigência das lentes injetadas - (A) policarbonato, (B) poliestireno.

Da mesma forma que para o acrílico, o tratamento térmico ocasiona ao mesmo tempo a diminuição da birrefrigência e a deformação da superfície nas lentes de policarbonato e 
poliestireno, com a observação adicional que para o policarbonato, é necessário tempo ou temperatura maior do que para os outros materiais.

A figura 7.4 apresenta a birrefrigência de uma lente acrílica comercial encontrada no mercado. Comparando-se as figuras 7.2 e 7.4, fica evidente que o nível de tensionamento das lentes obtidas nesse trabalho é aproximadamente o mesmo daquelas fabricadas por indústrias especializadas.

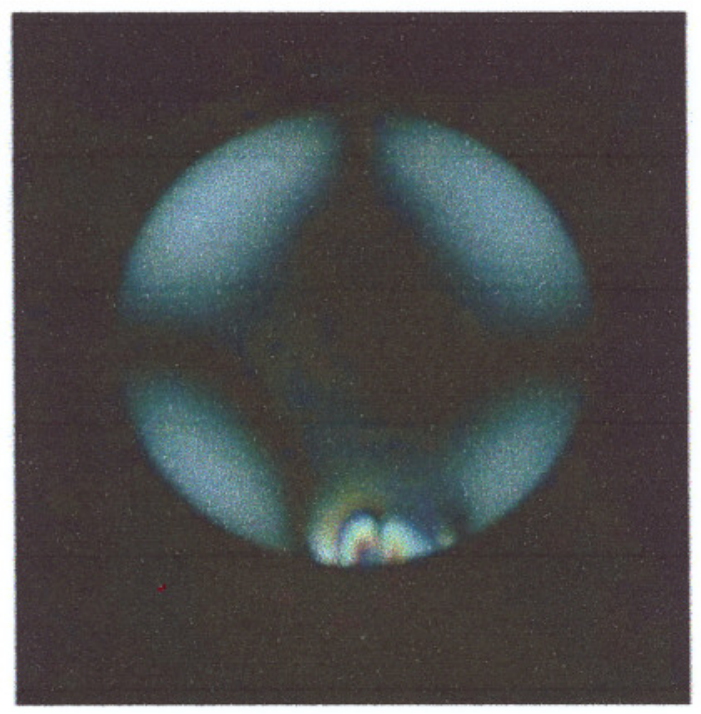

Figura 7.4 - Birrefrigência de lente acrílica comercial.

A análise da birrefrigência demonstra mais uma vez que o acrílico é o material adequado para o processo, apresentando baixo nível de tensionamento interno. $\mathrm{O}$ alto nível de tensionamento apresentado por materiais como o poliestireno e o policarbonato deve-se à temperatura de processamento necessária para redução da deformação que, para esses materiais, situa-se abaixo dos valores considerados ideais para suas condições de fluxo. No entanto, o aumento da temperatura desses dois materiais para além dos valores utilizados ocasionaria aumento significativo na deformação das lentes injetadas, conforme foi observado nos testes realizados.

\section{5 - Medida de Função de Transferência de Modulação - FTM}

\subsection{1 - Introdução}

Entre os diversos meios para se caracterizar um sistema óptico, destaca-se a medida através de funções de mérito, particularmente através da função de transferência óptica.

Para compreender a análise da qualidade de imagem, é preciso entender o processo de formação da imagem como uma transformada de Fourier de dois estágios no qual o objeto e a imagem são definidos como uma distribuição de luz bidimensional de brilhância variável. Quando uma lente forma uma imagem, a distribuição de luz do objeto é transformada 
do domínio espacial linear a um espectro do objeto no domínio da freqüência espacial, passando através de um filtro passa-banda de freqüência espacial, e novamente transformada no domínio espacial linear para se tornar uma distribuição de luz da imagem. Se o sistema de lentes é considerado como sendo o filtro passa-banda de freqüência espacial, seu efeito sobre a qualidade da imagem pode ser especificado em termos de uma curva passa-banda de freqüência espacial. Esta função de mérito é definida como Função de Transferência Óptica (FTO) que é o núcleo da teoria que trata de medidas de qualidade de imagens. Uma abordagem mais detalhada da FTO pode ser encontrada em Yasuoka (1997).

A FTO descreve a resposta de sistemas ópticos a uma fonte conhecida e é composta de duas componentes: FTM, a magnitude da FTO, e FTF, a fase de FTO. É a interpretação da FTM que será descrita nesse capitulo.

Um tipo de objeto comumente utilizado para testar a performance de sistemas ópticos consiste de uma série alternada de barras claras e escuras de igual espessura, como pode ser visto na figura $7.5 \mathrm{~A}$.

Vários conjuntos de padrões de diferentes espaçamentos são usualmente transmitidos através do sistema sob teste e o mais diminuto conjunto no qual a estrutura de linhas ainda pode ser discernida é considerado o limite de resolução do sistema, que é expresso como um certo número de linhas por milímetro. Quando um padrão de barras desse tipo é transmitido através de um sistema óptico, cada linha de largura infinitesimal do objeto é transmitida como uma linha difusa, cujo corte transversal é a função de espalhamento linear. Na figura $7.5 \mathrm{~B}$, é indicada uma seção transversal da brilhância do objeto em forma de barras e a figura 7.5C mostra como a imagem da função de espalhamento arredonda os cantos da imagem. Na figura 7.5D, é mostrado o efeito da imagem difusa sobre um padrão progressivamente mais bem definido. É aparente que, quando o contraste da iluminação na imagem é menor que a menor porção que o sistema pode detectar, o padrão não pode mais ser resolvido.

Se, o contraste da imagem é expresso como uma modulação dada pela equação,

$$
\text { Modulação }=\frac{\max .-\min .}{\max .+\min .}
$$

onde max. e min. são como indicados na figura 7.5D, então pode-se representar graficamente a modulação como uma função do número de linhas por milímetro como indicado na figura 7.6A. A intersecção da linha da função de modulação com a linha horizontal representa a menor quantia de modulação, que o sistema pode detectar e que dará o limite de resolução do sistema.

Deveria ser aparente que o limite de resolução não descreve totalmente a performance do sistema. A figura 7.6B mostra curvas de modulação com a mesma resolução limite, mas com performances bastante diferentes. A curva 1 com maior modulação na mais 
baixa freqüência, é obviamente superior à curva 2 , desde que produz imagens com maior contraste. Agora, considerando-se a figura 7.6C, onde um sistema mostra resolução limite extremamente alta e outro mostra alto contraste à baixa freqüência, percebe-se que a decisão entre qual dos sistemas é melhor, deve levar em consideração a função do sistema.

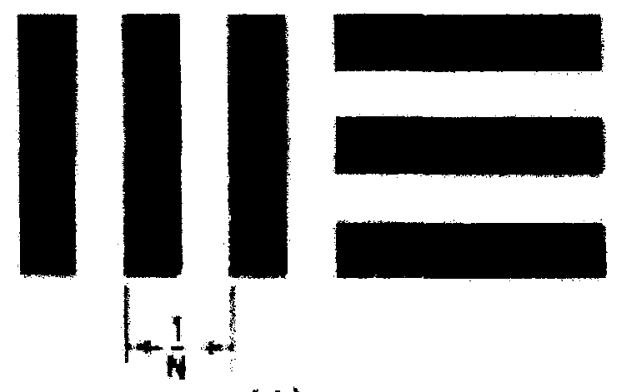

(A)

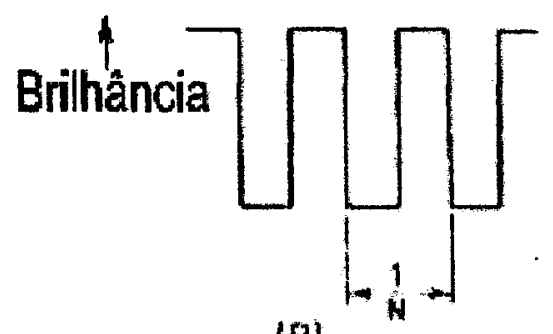

(B)
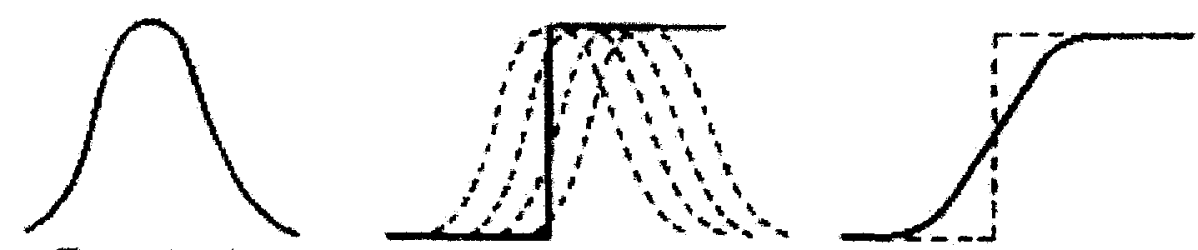

Função de Espalhamento

+ Objeto (aresta) $\rightarrow$ (aresta) Imagem

(c)
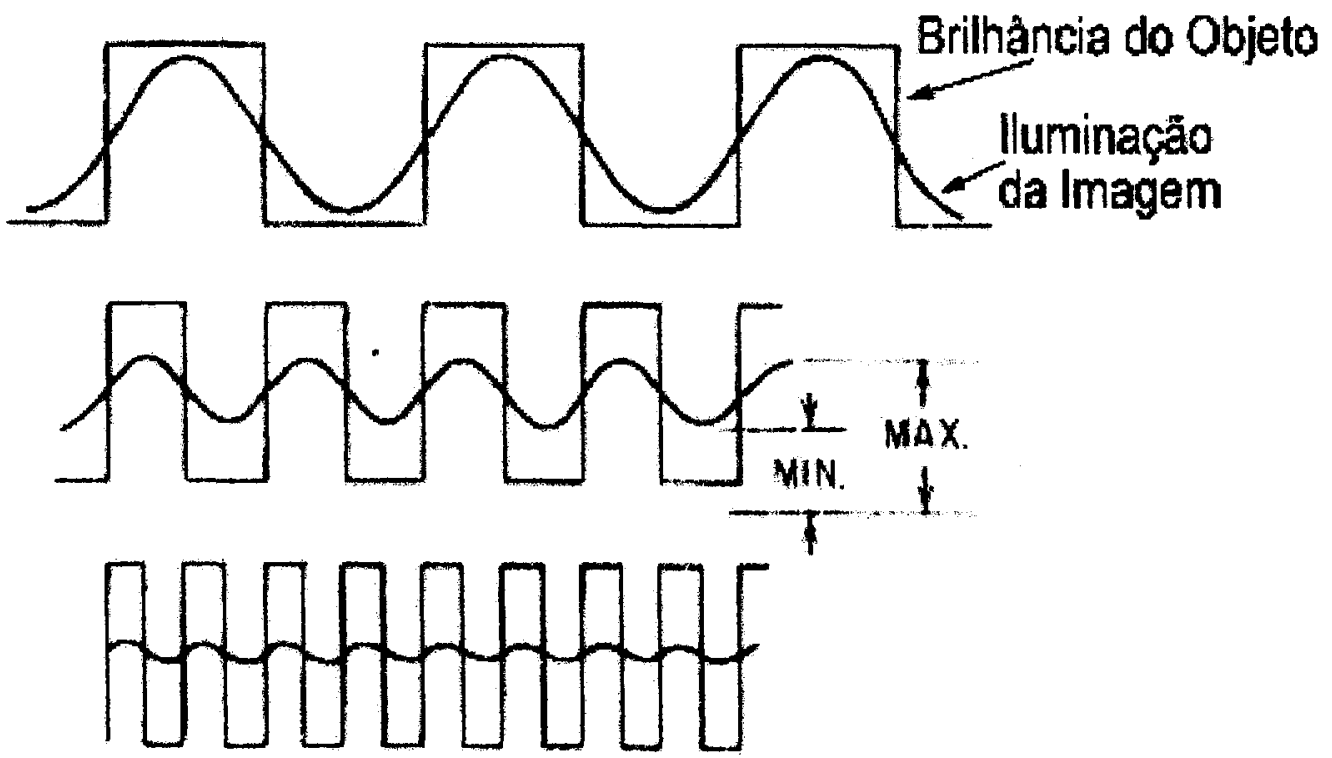

(d)

Figura 7.5 - Padrão de linhas e formação da imagem em testes ópticos (Smith, 1966). 

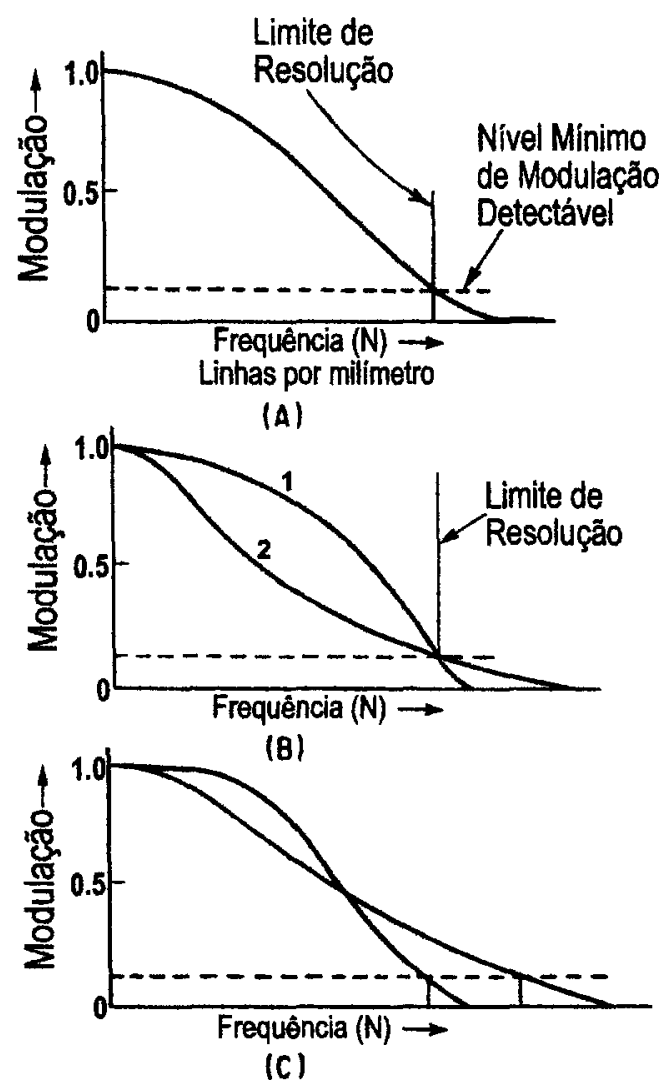

Figura 7.6 - Contraste da imagem como função da freqüência espacial (Smith, 1966).

A discussão precedente foi baseada em padrões cuja distribuição de brilhância é uma onda quadrada e cuja distribuição de iluminação da imagem é distorcida pela característica do sistema óptico. Porém, se o objeto padrão está na forma de uma onda senoidal, a distribuição na imagem é também descrita pela onda senoidal, sem levar em consideração a forma da função de espalhamento. Este fato tem levado ao extenso uso da função de transferência de modulação óptica para descrever a performance de sistemas de lentes. A FTM é a razão da modulação na imagem para aquela no objeto como uma função de freqüência (ciclos por unidade de comprimento) de um padrão de onda senoidal.

$$
F T M_{v}=\frac{M_{i}}{M_{0}}
$$

Um gráfico da FTM contra a freqüência $v$ é, portanto, uma medida quase universal para se determinar a performance de uma imagem formada por um sistema óptico(Smith, 1966).

\subsection{2 - A Resolução do Olho Humano}

Para a visualização dos resultados das medidas de FTM, utilizam-se gráficos que representam índices de contraste contra a freqüência, que é dada em números de linhas por milímetro. Considerando-se cada uma dessas linhas com largura infinitesimal, a freqüência 
representa a resolução utilizada pelo equipamento, para a realização das medidas. Para melhor interpretação dos resultados, é interessante a comparação com a resolução máxima do olho humano.

O limite de resolução de instrumentos ópticos é dado pela equação: (Yasuoka, 1997)

$$
\alpha=\frac{1,22 \lambda}{D}
$$

Sendo:

$\alpha=$ ângulo visual em radianos;

$\lambda=$ comprimento de onda da luz;

$D=$ diâmetro de abertura do sistema.

O ângulo visual, representa o menor ângulo formado pelo olho do observador e entre dois pontos, que continuam separados e definidos.

Com as seguintes considerações:

1. O sistema é o olho humano, com a abertura representada pela pupila com diâmetro $D$;

2. A distância de leitura para uma pessoa com visão normal é de $250 \mathrm{~mm}$;

3. Um arranjo de $N$ linhas, de largura infinitesimal, distribuídas em um espaço de 1 $\mathrm{mm}$, apresenta a distância entre linhas de $1 / \mathrm{N} \mathrm{mm}$.

Pode-se então, reescrever a equação 7.3 da seguinte forma:

$$
\frac{1}{250 N}=\frac{1,22 \lambda}{D}
$$

Em condições normais de iluminação, a pupila tem o diâmetro de $2 \mathrm{~mm}$. Resolvendo a equação 7.4 para $\lambda=\left(570 \times 10^{-6} \mathrm{~mm}\right)$ e $D=(2 \mathrm{~mm})$, obtém-se:

$$
\mathrm{N} \cong 11,5
$$

Resultando em um ângulo visual de aproximadamente 1', ou seja, o limite de resolução usualmente aceito para o olho humano (HORNE, 1978). Para $D=(6 \mathrm{~mm})$, encontra-se como resultado:

$$
\mathrm{N} \cong 34,5
$$

Assim, a resolução máxima do olho humano é da ordem de 34 linhas por milímetro. Esse valor, representa o limite imposto pela Física e pela físiologia do olho humano. Na prática, somente pessoas com acuidade visual excepcional apresentariam valores próximos dessa resolução.

Considerando-se a aplicação proposta para as lentes injetadas, é importante que as mesmas apresentem qualidade satisfatória principalmente para baixas freqüências. 


\subsection{3 - Medida de FTM das Lentes Injetadas}

A medida de FTM das lentes injetadas foi realizada por uma estação de teste automática Optomatic da empresa Trioptics. Para as medições realizadas, utilizou-se no sensor uma lente com aumento de 1x. Para cada uma das amostras foram realizadas 5 medidas. As médias dos valores obtidos foram utilizadas para compor os gráficos ilustrados nas figuras apresentadas a seguir, onde são apresentadas as curvas de várias amostras agrupadas de acordo com o material de injeção utilizado. Cada um dos gráficos traz também a curva característica da MTF de uma lente padrão, que acompanha a estação de testes para comparação.

A figura 7.7 apresenta a análise gráfica da FTM para as amostras injetadas em acrílico 01-DH-LE. Nessa figura, destaca-se o comportamento anômalo da curva "E", onde se tem um contraste para freqüências intermediárias maior do que para freqüências mais baixas. Esse tipo de resultado deve-se, provavelmente, à baixa qualidade observada na superficie da lente que impede uma medida precisa por parte do equipamento.

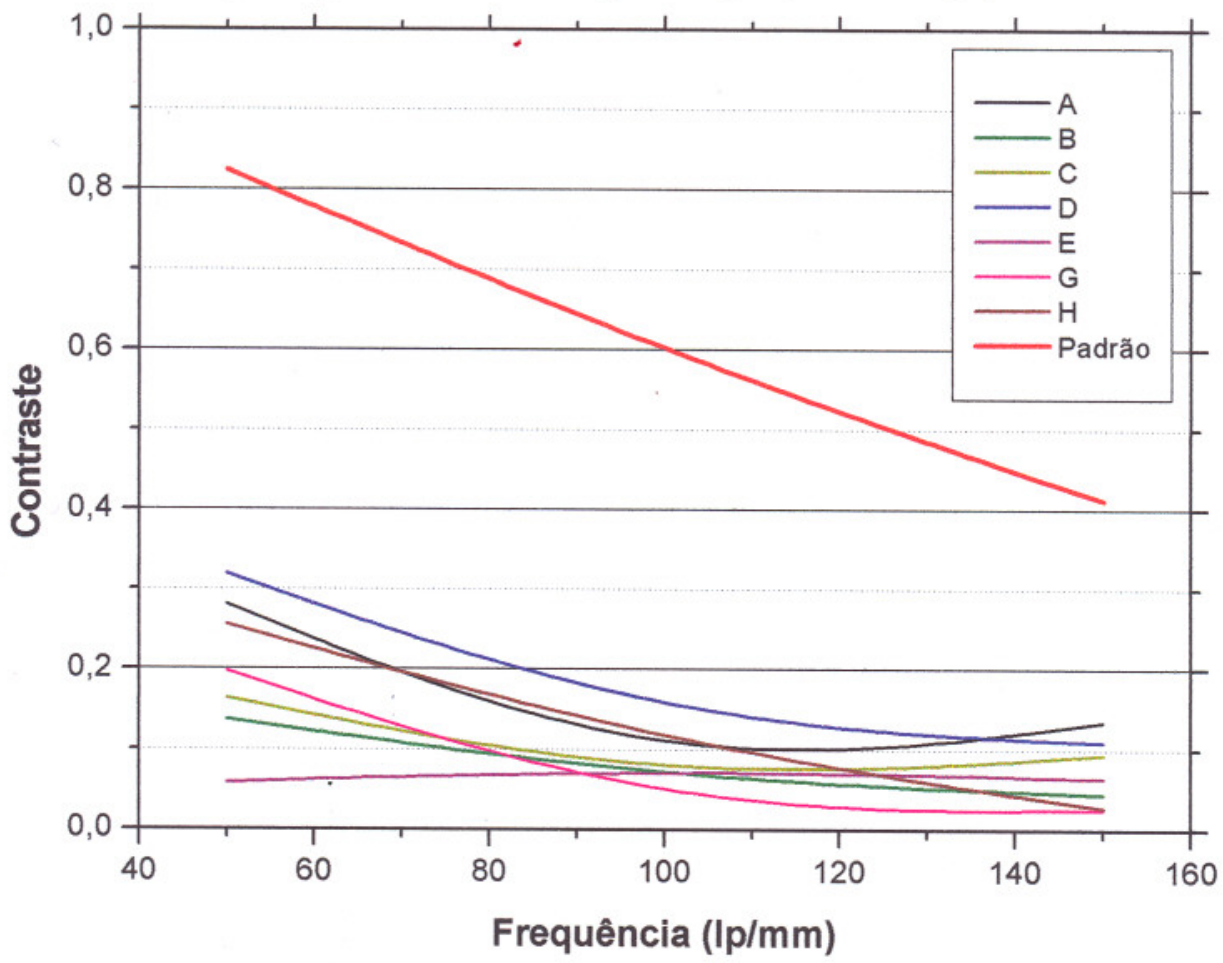

Figura 7.7 - Análise gráfica da FTM das amostras de acrílico 01-DH-LE.

$\mathrm{Na}$ figura 7.8, pode-se verificar a qualidade das lentes injetadas em poliestireno. Uma observação que se faz com base na figura 7.8 é que a curva de FTM não pode ser o único indicador de qualidade, pois as lentes injetadas em poliestireno têm um aspecto visual (baixa transparência, presença de bolhas), que inibe sua utilização para aplicações básicas e, no entanto, apresentam um índice de contraste compatível com a de algumas das lentes injetadas em acrílico e com melhor aspecto visual. 


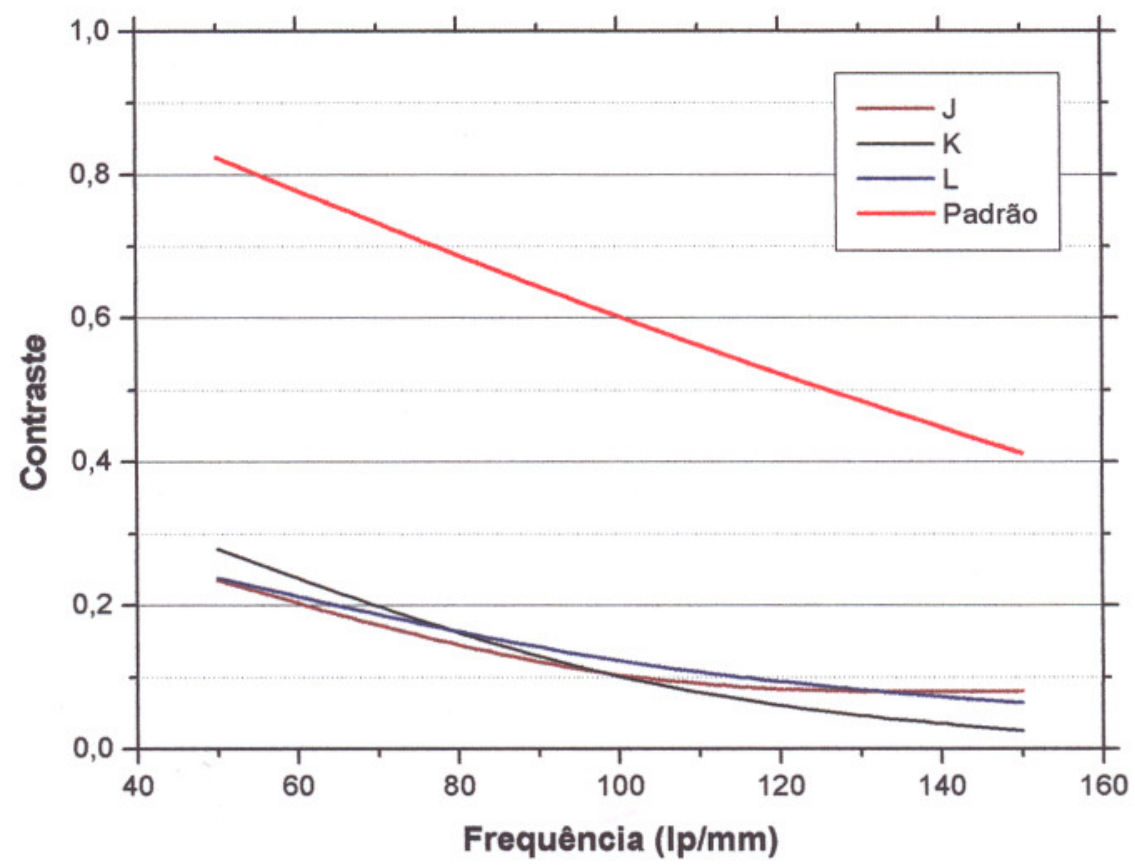

Figura 7.8 - Análise gráfica da FTM das amostras de poliestireno.

As medidas de FTM das amostras injetadas com o acrílico 01-DH-ECL são apresentadas na figura 7.9. Apesar de se apresentarem visualmente melhores que as amostras dos testes iniciais, as curvas de contraste desses dois grupos de amostras são muito parecidas.

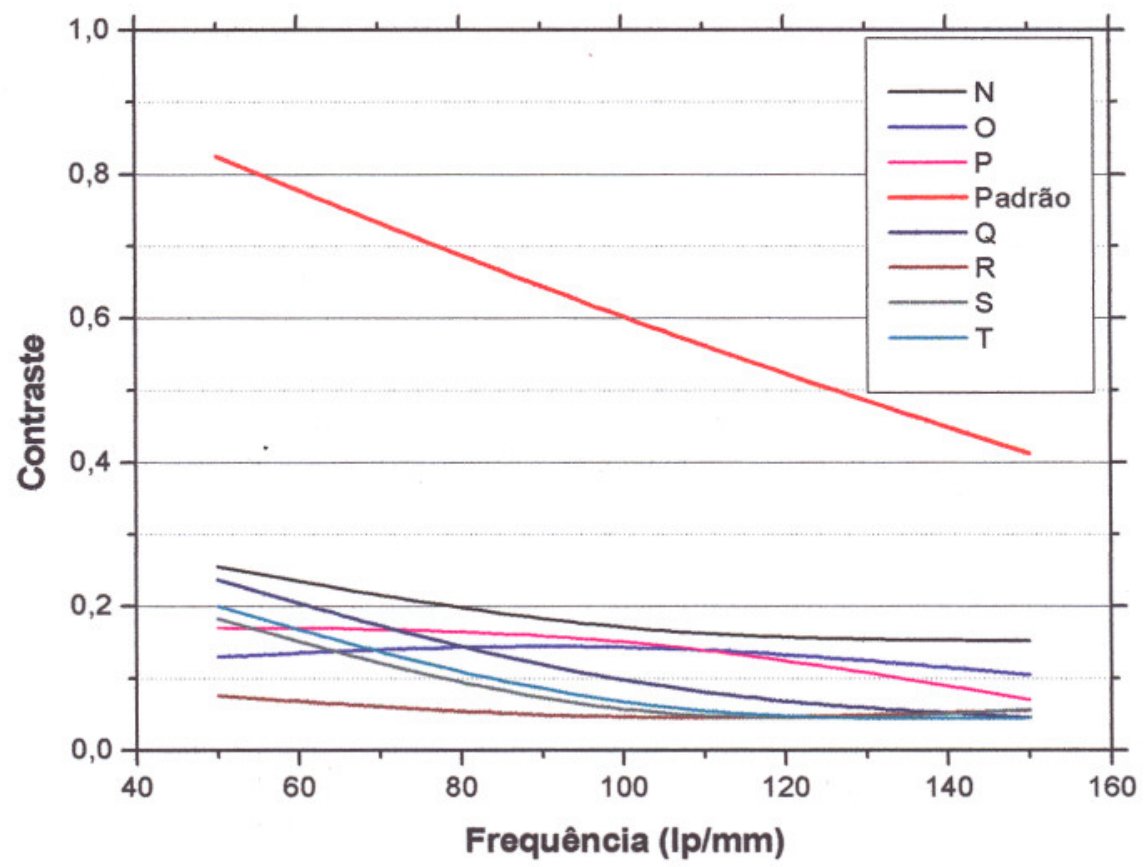

Figura 7.9 - Análise gráfica da FTM das amostras de acrílico 01-DH-ECL.

O acrílico 01-DH-ECL-P, indicado pela empresa Metacril para aplicações ópticas mais críticas, foi utilizado nos testes finais e o resultado obtido para a amostra $\mathrm{Z}$ foi 
considerado satisfatório para a aplicação desejada. O resultado das medidas de FTM desses testes pode ser visualizado na figura 7.10 , onde se destaca a curva da amostra $\mathrm{Z}$ com maiores valores de contraste a baixas e médias freqüências.

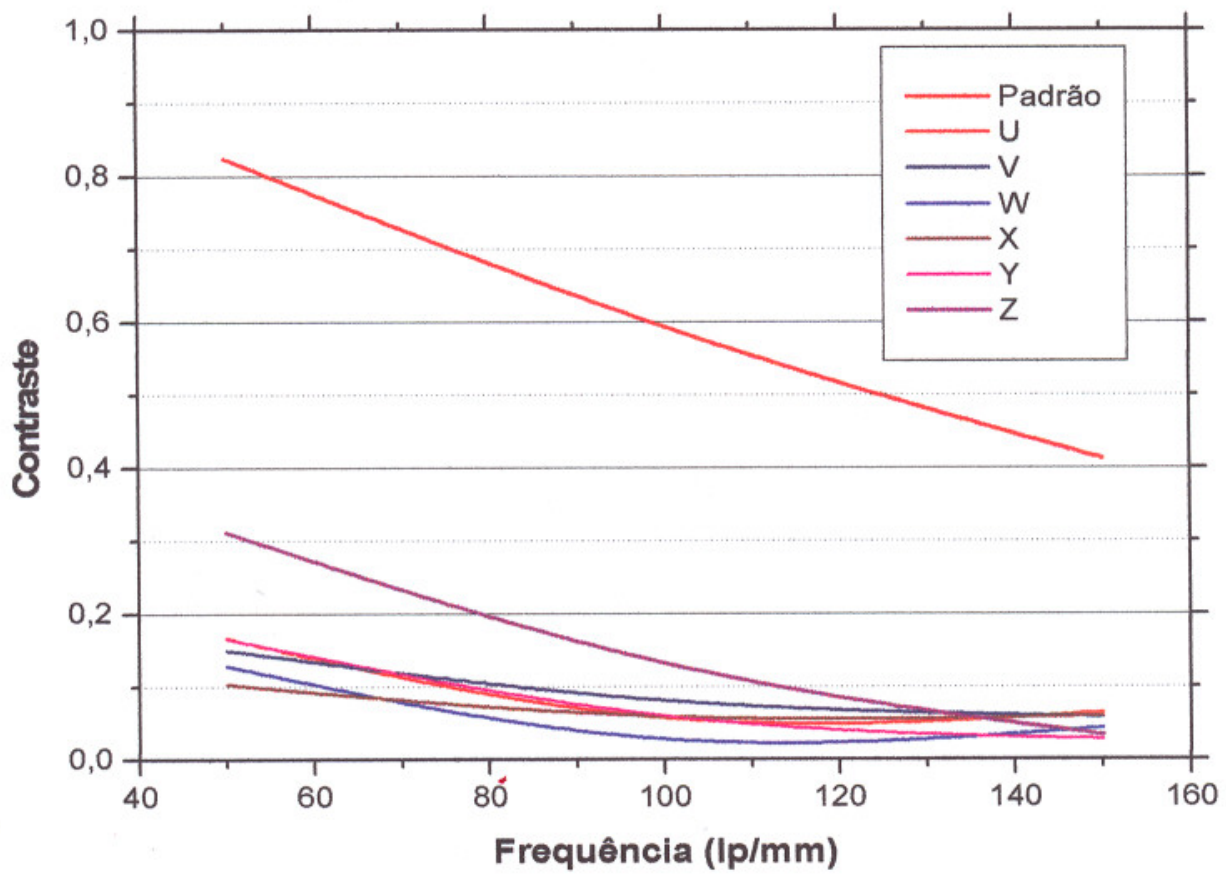

Figura 7.10 - Análise gráfica da FTM das amostras de acrílico 01-DH-ECL-P.

Finalmente, na figura 7.11 são apresentadas as curvas de FTM de lentes termomoldadas no CDCC, de lentes comerciais de vidro polido e de acrílico encontradas no mercado brasileiro. São também apresentadas as curvas de lentes fabricadas pelo IFSC para utilização no ensino e as curvas da lente padrão da estação de medida e da amostra $Z$ para comparação. Informações mais detalhadas dessas lentes são encontradas na tabela 7.1. A figura 7.11 demonstra que a curva da amostra obtida por injeção apresenta resultados muito próximos à da lente de vidro com diâmetro de $75 \mathrm{~mm}$ e da comercial acrílica para médias e baixas freqüências. As lentes termo-moldadas e em vidro com diâmetro de $60 \mathrm{~mm}$ têm os mais altos valores de contraste, ainda que abaixo da lente padrão e do IFSC. Em contrapartida, a amostra $\mathrm{Z}$ apresenta melhores resultados que a lente em vidro de diâmetro de $40 \mathrm{~mm}$.

Como observação final, fica evidente, através da figura 7.11, que a amostra $\mathrm{Z}$ obtida nos testes finais apresenta uma curva de FTM com um padrão muito próximo da curva de lentes comerciais de baixo custo. 
Tabela 7.1 - Características de lentes de procedência variada.

\begin{tabular}{|l|c|c|c|l|}
\hline Amostra & $\begin{array}{l}\text { Foco } \\
(\mathrm{mm})\end{array}$ & $\begin{array}{l}\text { Diâmetro } \\
(\mathrm{mm})\end{array}$ & $\begin{array}{l}\text { Preço } \\
(\mathrm{US} \$)\end{array}$ & Características \\
\hline Padrão & 100,02 & 40 & - & $\begin{array}{l}\text { Lente padrão para calibração, que acompanha a } \\
\text { estação de testes. }\end{array}$ \\
\hline IFSC & 99,95 & 50 & 15,00 & $\begin{array}{l}\text { Lente fabricada na oficina de óptica do IFSC, } \\
\text { em vidro comum para fins didáticos (usadas } \\
\text { nos laboratórios de ensino). }\end{array}$ \\
\hline $\begin{array}{l}\text { Comercial } \\
\text { acrílica }\end{array}$ & 193,00 & 75 & 2,50 & $\begin{array}{l}\text { Lente comercial injetada em acrílico, vendida } \\
\text { sob a forma de lupa. }\end{array}$ \\
\hline Vidro 1 & 72,70 & 40 & 0,70 & $\begin{array}{l}\text { Lente de vidro comum, de procedência chinesa, } \\
\text { vendida sob a forma de lupa. }\end{array}$ \\
\hline Vidro 2 & 111,50 & 60 & 0,70 & $\begin{array}{l}\text { Lente de vidro comum, de procedência chinesa, } \\
\text { vendida sob a forma de lupa. }\end{array}$ \\
\hline Vidro 3 & 281,30 & 75 & 0,70 & $\begin{array}{l}\text { Lente de vidro comum, de procedência chinesa, } \\
\text { vendida sob a forma de lupa. }\end{array}$ \\
\hline $\begin{array}{l}\text { Termo- } \\
\text { moldada }\end{array}$ & 106,60 & 50 & 1,70 & $\begin{array}{l}\text { Lente fabricada no CDCC, por meio de } \\
\text { moldagem à vácuo de discos aquecidos obtidos } \\
\text { de chapas de acrílico comercial. }\end{array}$ \\
\hline
\end{tabular}

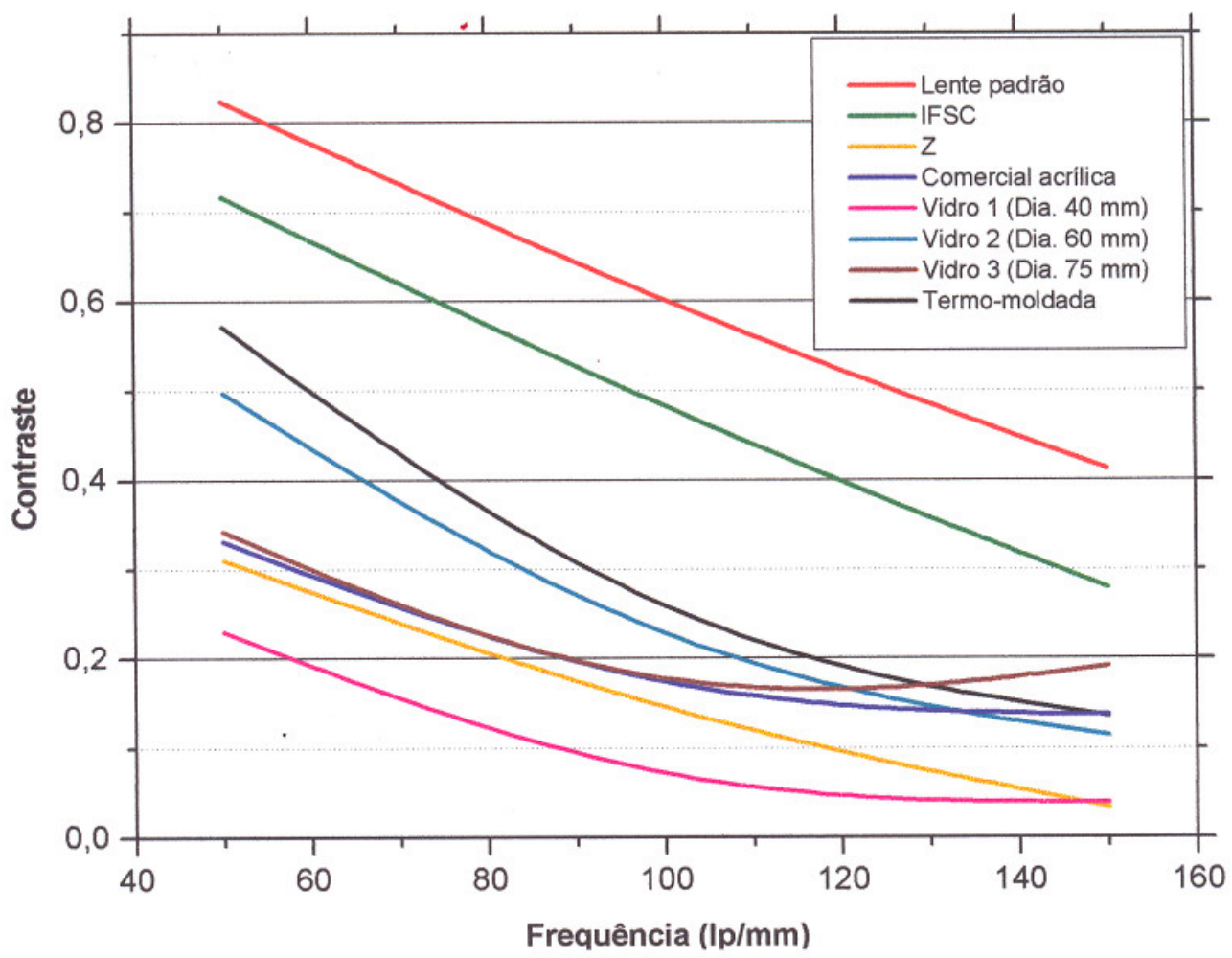

Figura 7.11 - FTM - lentes Z, lentes comerciais, lente do IFSC e lente padrão.

\section{6 - Medida da Distância Focal}

A medida da distância focal foi realizada pela estação de teste automática Optomatic, a mesma utilizada para medidas de FTM. Para as medições realizadas, utilizou-se no sensor uma lente com aumento de 1x. Foram realizadas 3 medidas para cada uma das amostras. 
As lentes de poliestireno apresentam distância focal de aproximadamente $85 \mathbf{~ m m}$, enquanto que as lentes de acrílico apresentam distância focal que varia entre 105 a 125. Observando-se que a amostra "Z" apresenta distância focal de 124,6 mm.

Para análise do resultado dessas medidas é importante verificar se os valores encontrados são condizentes com a geometria da lente. Aplicando-se a fórmula dos fabricantes de lentes:

$$
\frac{1}{f}=\left(n_{i}-n_{e}\right) \cdot\left(\frac{1}{r_{1}}-\frac{1}{r_{2}}\right)
$$

onde,

$f=$ Distância focal;

$n_{i}=$ Índice de refração do material da lente;

$n_{e}=$ Índice de refração do meio;

$r_{1}$ e $r_{2}=$ Raios de curvatura de ambos os lados da lente.

obtém-se, para o raio de curvatura de $100 \mathrm{~mm}$, uma distância focal de 100,6 mm para lentes em acrílico. Agora, aplicando-se a equação para lentes em poliestireno, o valor obtido para a distância focal é de $82,78 \mathrm{~mm}$.

Assim, observa-se que as lentes injetadas em acrílico, em particular as amostras " $Z$ ", devem apresentar raio de curvatura diferente daquele que foi projetado. De fato, o mapeamento realizado e descrito no item 7.7 demonstrou que a superficie da cavidade do molde é asférica, assim como a lente obtida.

\section{7 - Mapeamento das Superfícies das Cavidades e das Lentes}

\subsection{1 - Introdução}

Pôde-se verificar, visualmente, que as lentes obtidas apresentam deformações. Com o objetivo de identificar a intensidade dessas deformações, realizou-se o mapeamento das superficies das cavidades do molde e das lentes pertencentes ao lote de testes " $\mathrm{Z}$ " e também de lentes injetadas em policarbonato e poliestireno, das quais as melhores amostras foram analisadas.

Por tornar o texto mais simples, adota-se desse ponto em diante o nome de face inferior da lente para a face correspondente ao inserto inferior e o nome de face superior da lente para aquela correspondente ao inserto superior. A figura 5.2 pode auxiliar na interpretação dessas definições. 
O mapeamento foi realizado utilizando-se o equipamento para aferição de superfícies TALYSURF - 120L fabricado pela TAYLOR-HOBSON. Esse instrumento, com limite de resolução da ordem de $10^{-8} \mathrm{~m}$, permite o mapeamento de superfícies, indicando o nível de rugosidade, o raio que mais se aproxima do perfil sob análise e a sequiência de pontos, que representa as coordenadas $\mathrm{XZ}$ de cada perfil analisado.

Para as análises dos perfis, foi adotado como origem do sistema de coordenadas $o$ centro das cavidades ou da lente para os eixos $\mathrm{X}$ e $\mathrm{Y}$ e o ponto de máximo e mínimo para a lente e a cavidade respectivamente. Para o alinhamento das cavidades e lentes, considera-se $o$ eixo $\mathrm{X}$ com coordenadas variando de -20 a 20 , na mesma orientação ou perpendicular ao fluxo de material que alimentou a cavidade durante a injeção, respectivamente são os perfis longitudinal e transversal, citados no texto e exemplificados na figura 7.12.

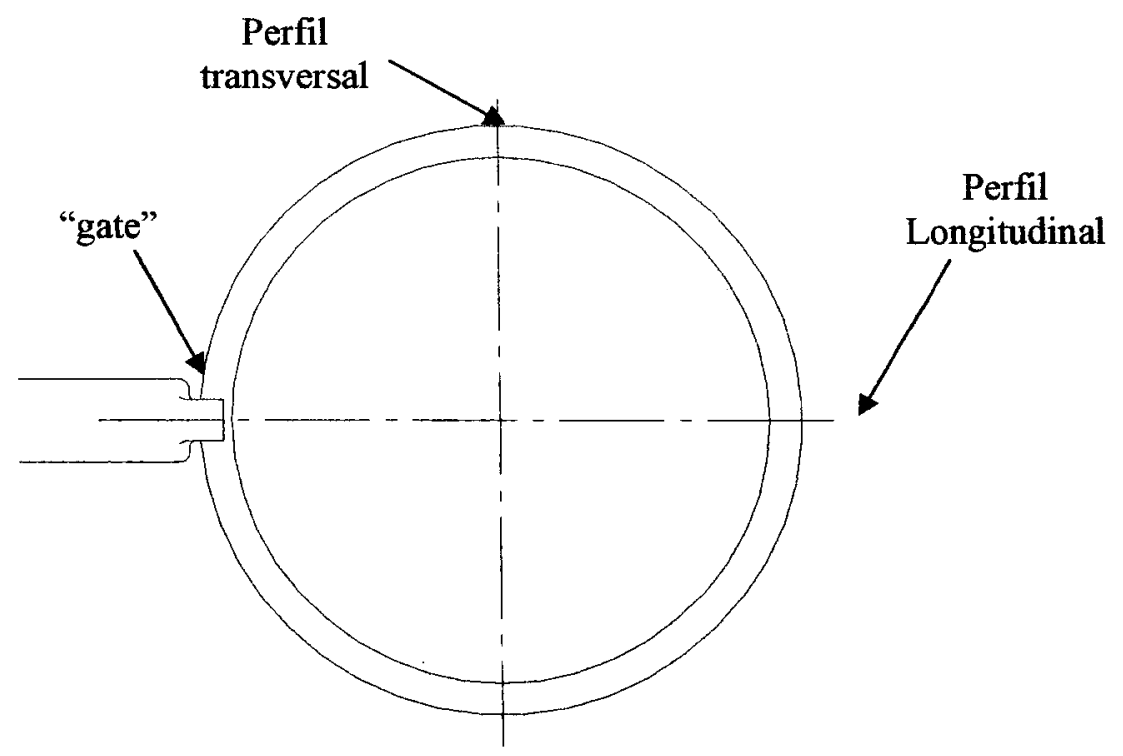

Figura 7.12 - Definição dos eixos transversal e longitudinal da lente e cavidades.

\subsection{2 - Resultado das medidas}

O raio projetado para cavidade foi de $100 \mathrm{~mm}$, no entanto, o mapeamento demonstrou que a superficie do inserto superior apresenta-se com um perfil próximo a um raio de $106 \mathrm{~mm}$. Um gráfico da diferença entre as coordenadas $X, Z$ para esse raio e as obtidas no mapeamento pode auxiliar na visualização da variação ocorrida. Tal gráfico é apresentado na figura 7.13. É possivel observar que a cavidade encontra-se descentralizada com relação ao eixo central, pois, as regiões ao redor das coordenadas $-10 \mathrm{~mm}$ e $10 \mathrm{~mm}$ apresentam pontos de máximo e de mínimo em lados opostos ao eixo central.

Para o inserto inferior, obtém-se o gráfico da figura 7.14, onde se analisa a diferença entre o perfil de um raio de $112,6 \mathrm{~mm}$ e o perfil do inserto superior. Assim, como no inserto superior, observa-se asfericidade e descentralização da superfície, também nesse caso. 
A comparação entre os perfis longitudinal e transversal de cada uma das cavidades demonstrou que não existe variação entre eles, ou seja, os perfis estão descentralizados mas possuem eixos de simetria axial.

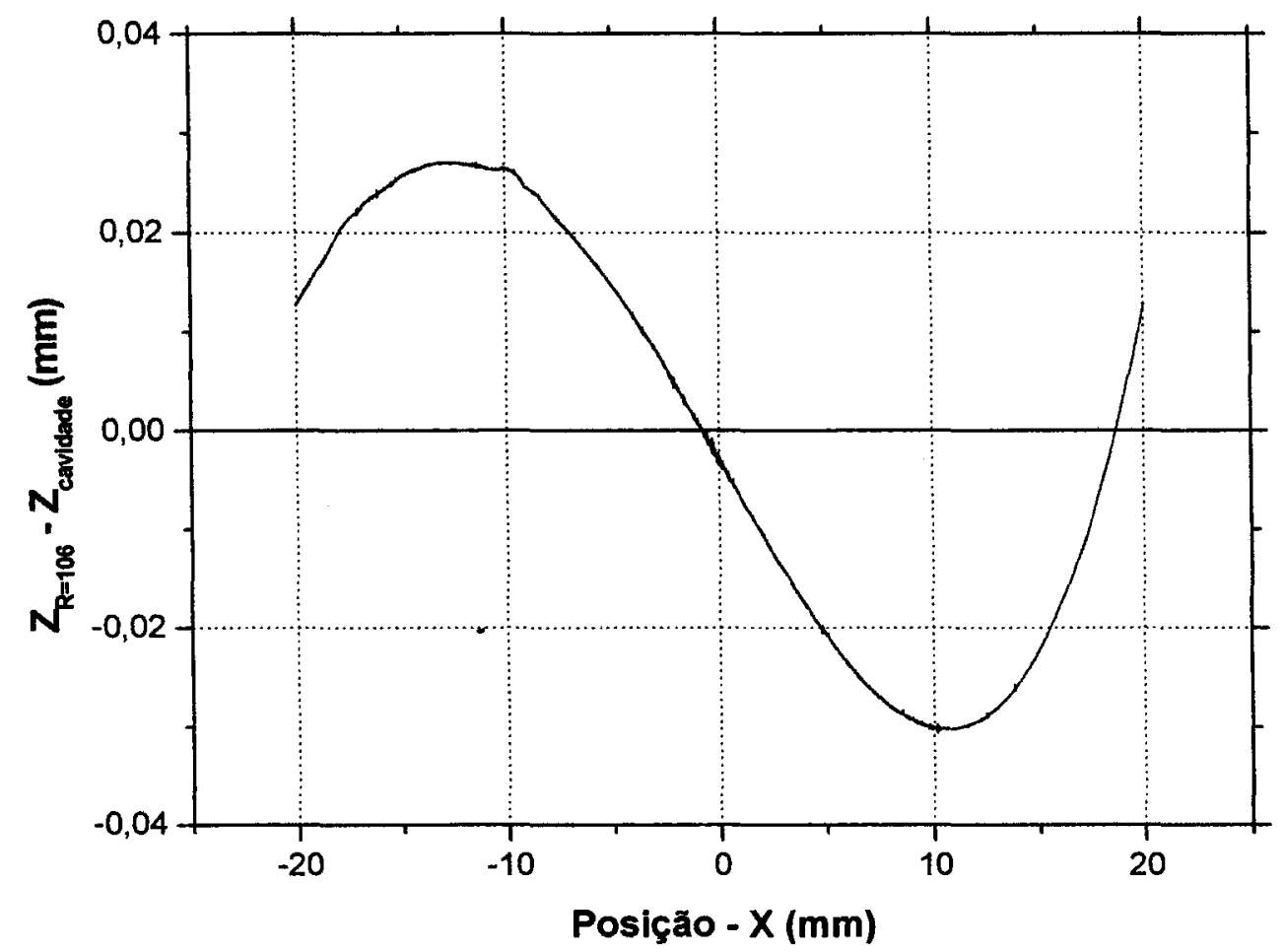

Figura 7.13 - Diferença entre perfil com $R=106 \mathrm{~mm}$ e o perfil longitudinal do inserto superior.

As coordenadas resultantes do mapeamento da face superior da lente permitiram a elaboração do gráfico demonstrado na figura 7.15. Nessa figura, o perfil da lente é comparado com o perfil longitudinal do inserto superior. Nesse gráfico, é possível observar a deformação máxima da lente em relação à cavidade que se situa em $0,13 \mathrm{~mm}$ na região periférica da lente. Uma parábola com concavidade positiva, centrada na origem, seria a curva característica para um gráfico desse tipo. Como se verifica na figura 7.15 , a curva está centralizada em torno do ponto -5 , além de apresentar deformação adicional na extremidade oposta à entrada de material.

Como informação adicional dessa face da lente, pode-se observar na figura 7.16 a variação ocorrida entre o perfil longitudinal da lente, alinhado com o fluxo, e o perfil transversal, perpendicular ao fluxo. A interpretação para essa curva é que o perfil transversal apresenta-se com a região central mais alta que as bordas, quando comparado com o perfil longitudinal. Por outro lado, na região próxima ao ponto de alimentação da cavidade, a pressão de recalque permite a entrada de material adicional, que compensa em parte a contração ocorrida durante o resfriamento. Isso explica a falta de simetria da curva com 
relação à origem do eixo $\mathrm{X}$ na figura 7.16. A figura 7.17 traz a comparação entre o perfil longitudinal da face superior da lente e o raio aproximado de $113,5 \mathrm{~mm}$. Nessa última figura, também observa-se que a região próxima à zona do "gate" tem maior aproximação com um perfil circular.

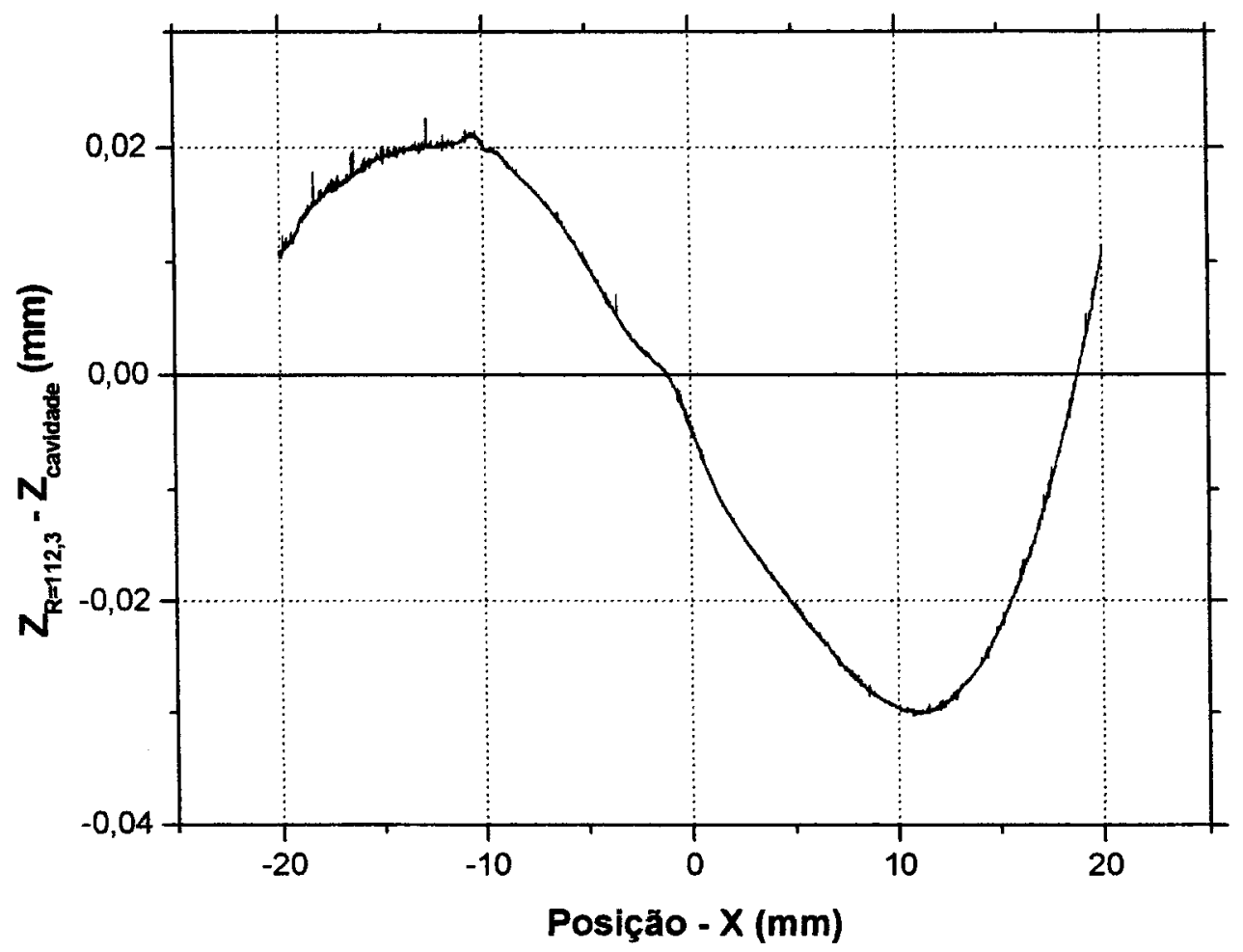

Figura 7.14 - Diferença entre perfil com $R=112,6 \mathrm{~mm}$ e o perfil longitudinal do inserto inferior.

Na análise da face inferior da lente, pode-se verificar na figura 7.18 a variação ocorrida com relação à cavidade, enquanto que a figura 7.19 apresenta a variação entre os perfis longitudinal e transversal. Quando se comparam as figuras 7.16 e 7.19, observa-se que as faces apresentam deformação oposta. Enquanto a face superior apresenta o perfil transversal com a as bordas mais rasas do que no perfil longitudinal, a face inferior apresenta o perfil longitudinal com as borda mais rasas. De fato, esse comportamento demonstra o deslocamento de parte do material de uma das faces para a outra. Finalizando, a análise dessa face, a figura 7.20 demonstra como varia a face inferior com relação a um raio de $118,1 \mathrm{~mm}$, onde é evidenciada a aproximação da zona do "gate" com o perfil circular, da mesma forma como ocorre para a face superior da lente.

A análise da deformação das lentes injetadas em policarbonato é apresentada por meio das figuras 7.21 e 7.22 , onde os perfis são comparados com os respectivos raios aproximados. Para as lentes injetadas em poliestireno, os resultados podem ser verificados nas figuras 7.23 e 7.24. Nessas últimas 4 figuras, verificam-se oscilações no perfil que 
ocorrem de forma brusca. $\mathrm{O}$ que torna as lentes injetadas em acrílico melhores em uma análise visual é o fato de que as variações do perfil dessas lentes ocorrerem de forma mais suave.

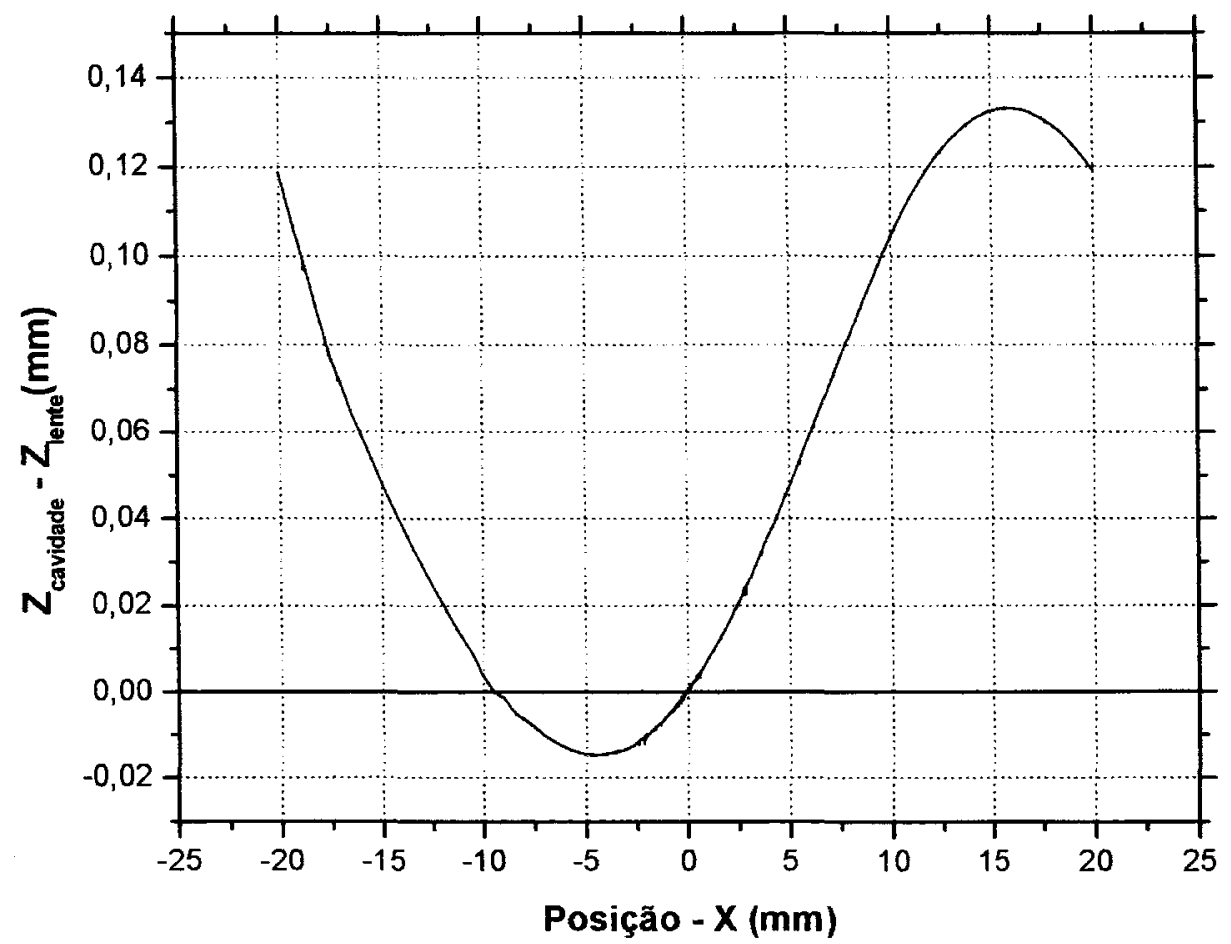

Figura 7.15 - Diferença entre o perfil da face superior da cavidade e o perfil longitudinal da face superior da lente $\mathrm{Z}$.

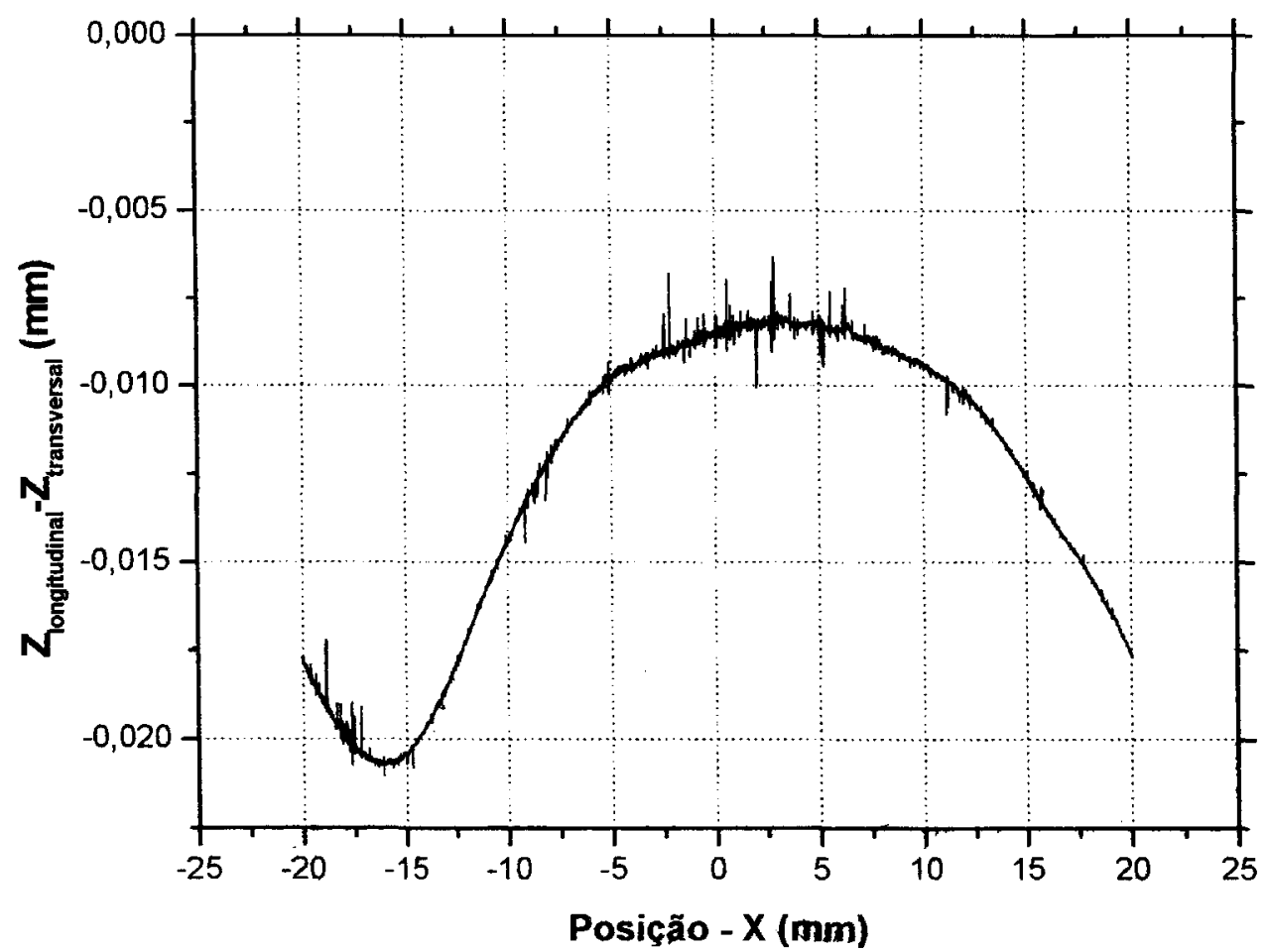

Figura 7.16 - Diferença entre perfis longitudinal e transversal da face superior da lente Z. 


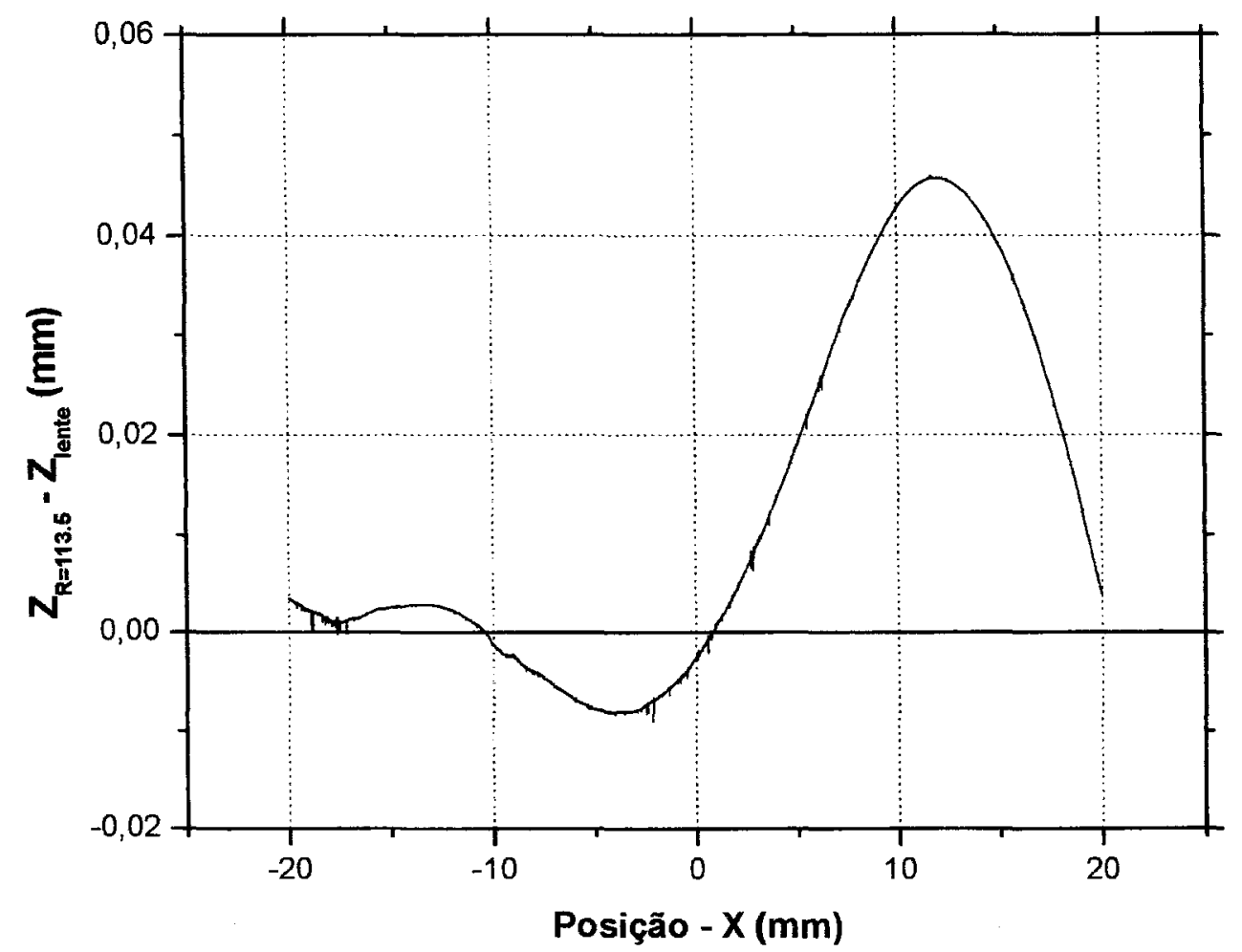

Figura 7.17 - Diferença entre perfil com $\mathrm{R}=113,5 \mathrm{~mm}$ e o perfil longitudinal da face superior da lente $Z$.

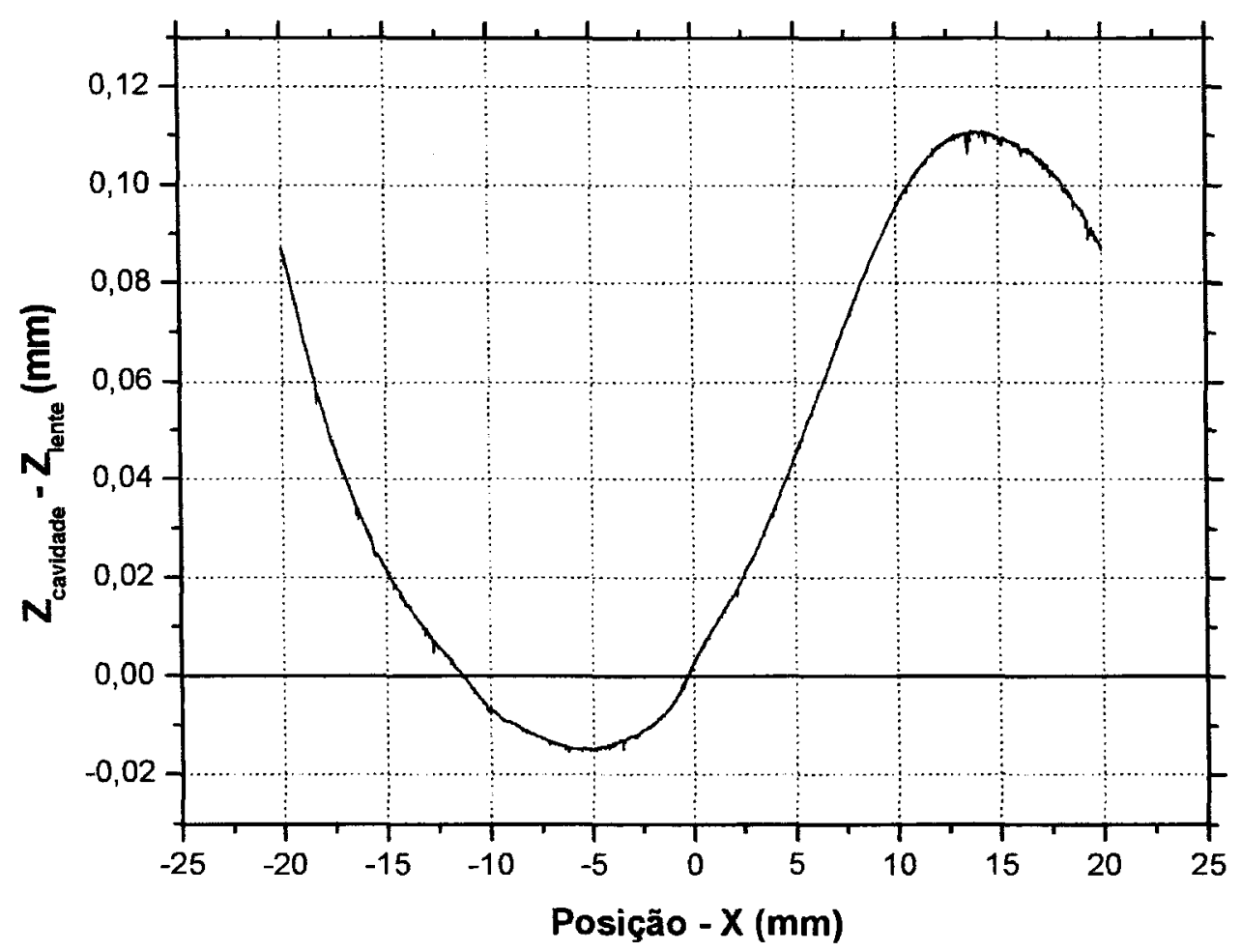

Figura 7.18 - Diferença entre o perfil da face inferior da cavidade e o perfil longitudinal da face inferior da lente $Z$. 


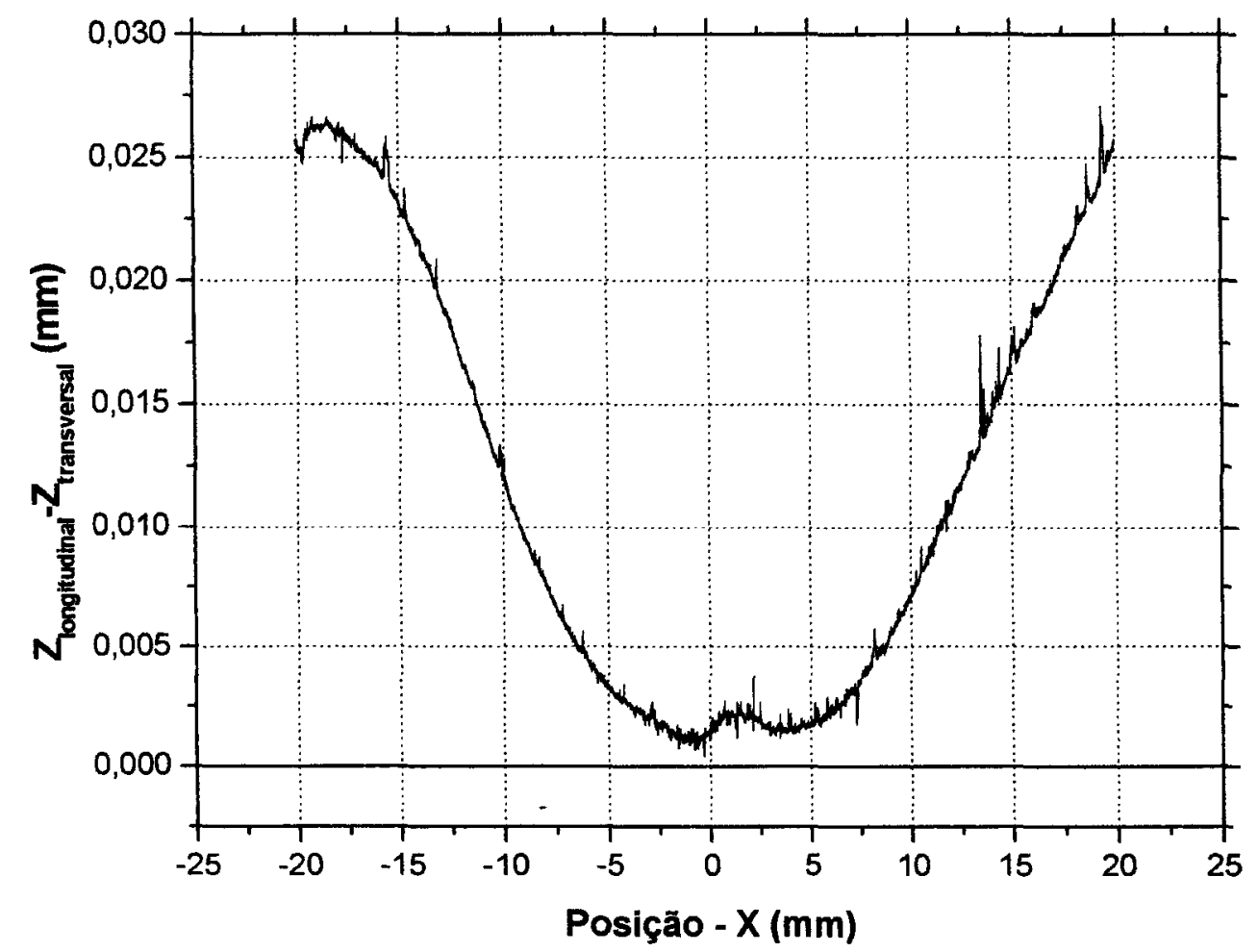

Figura 7.19 - Diferença entre perfis longitudinal e transversal da face inferior da lente Z.

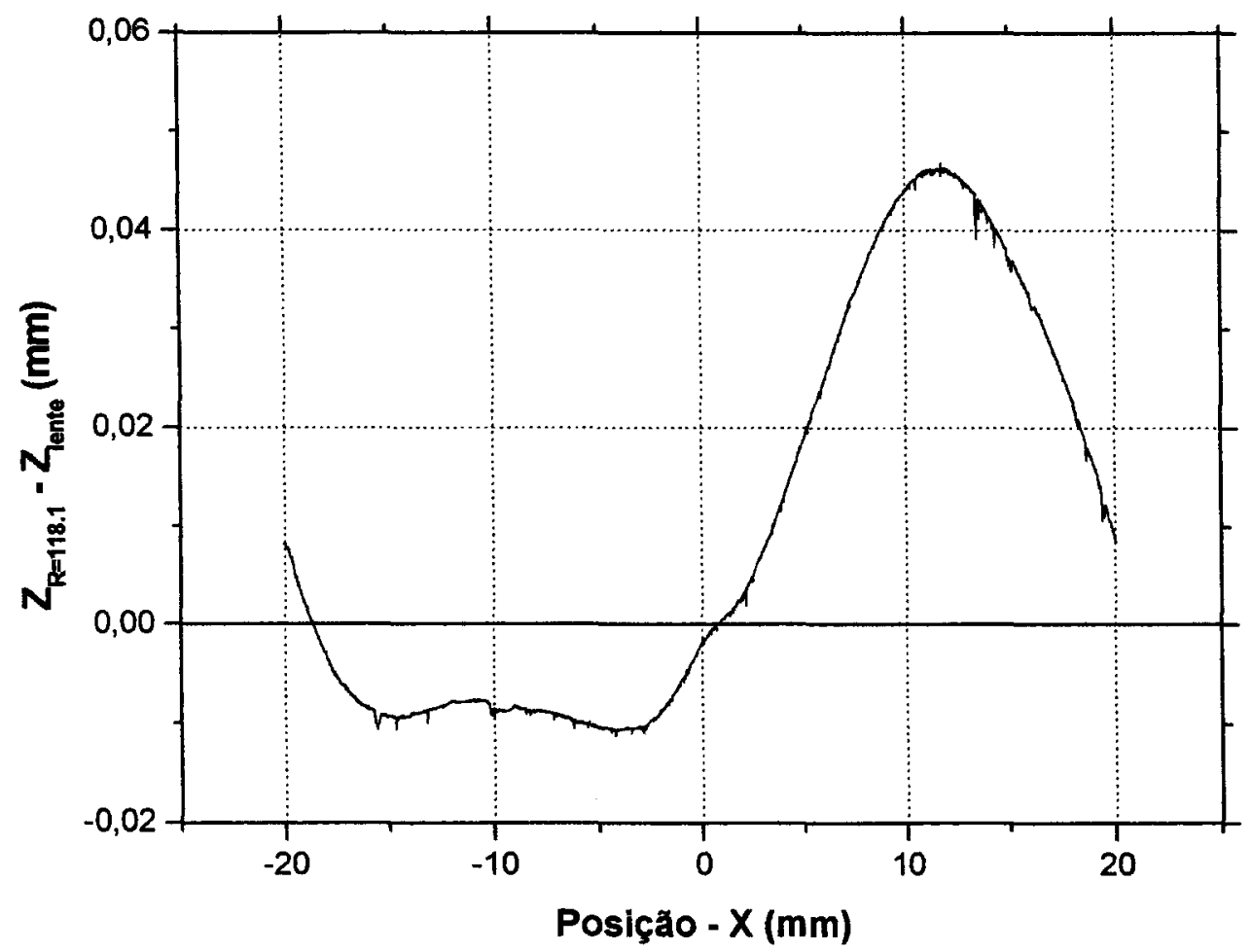

Figura 7.20 - Diferença entre perfil com $R=118,1 \mathrm{~mm}$ e o perfil longitudinal da face inferior da lente $Z$. 


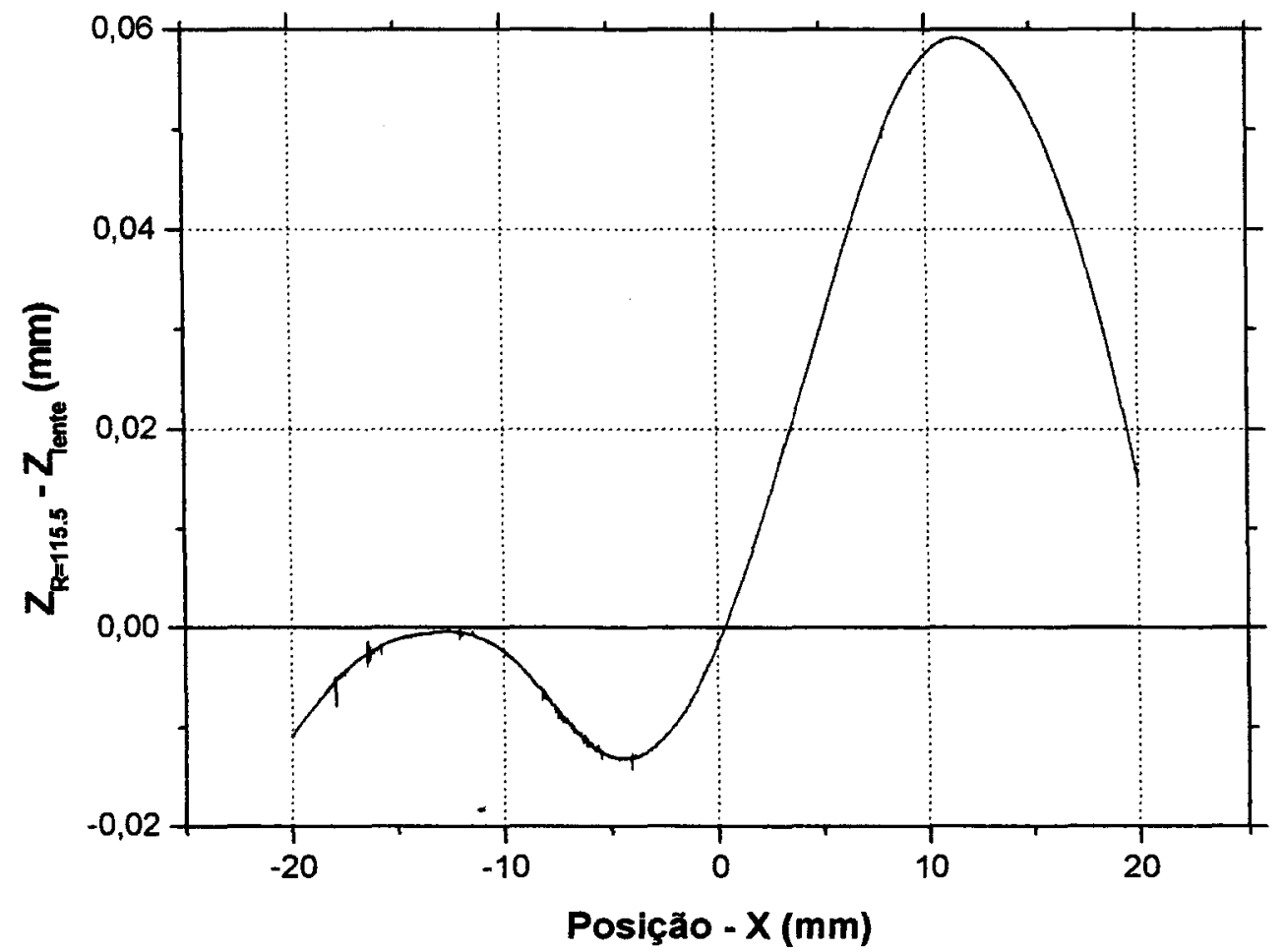

Figura 7.21 - Diferença entre perfil com $R=115,1 \mathrm{~mm}$ e o perfil longitudinal da face superior da lente de PC.

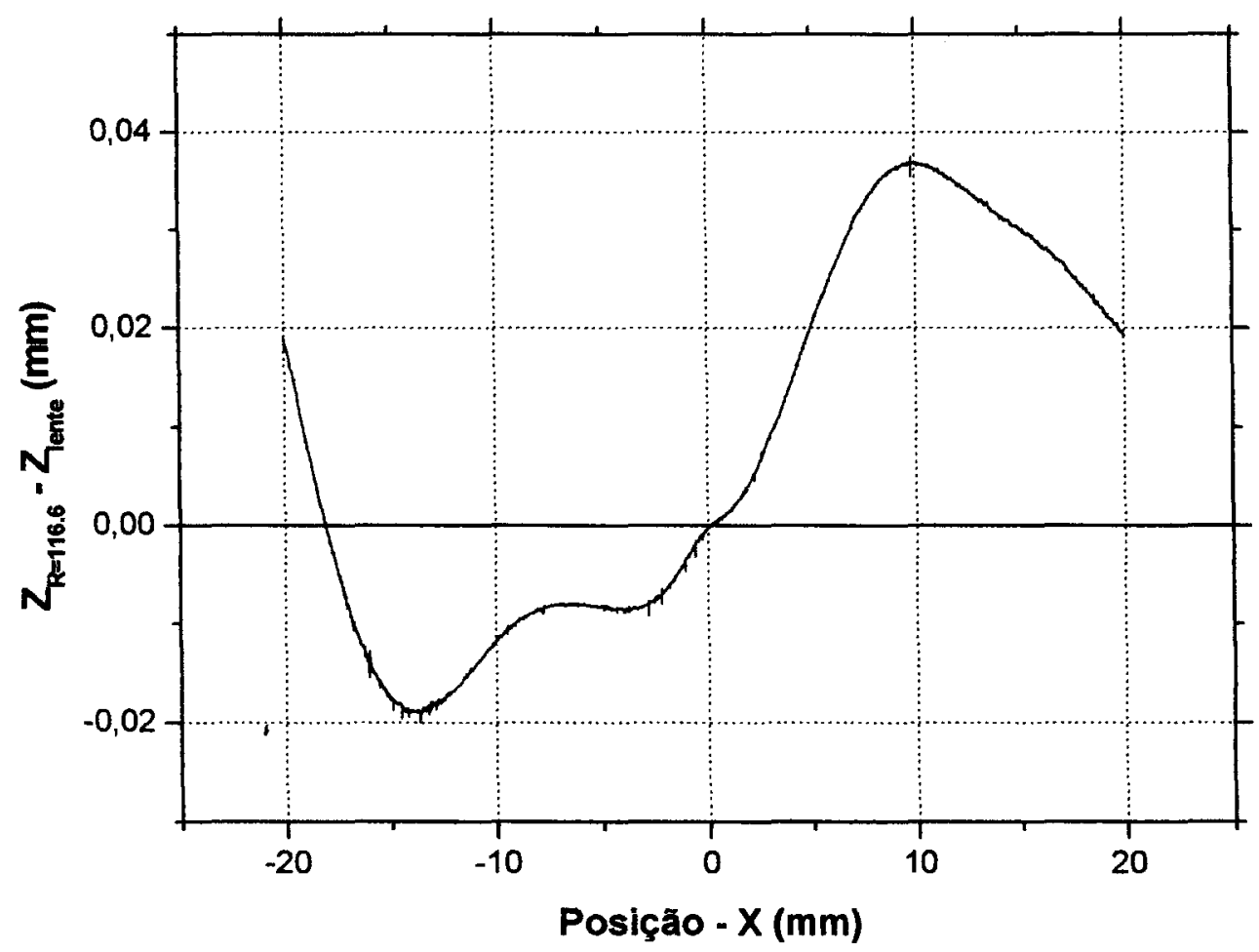

Figura 7.22 - Diferença entre perfil com $R=116,6 \mathrm{~mm}$ e o perfil longitudinal da face inferior da lente de PC. 


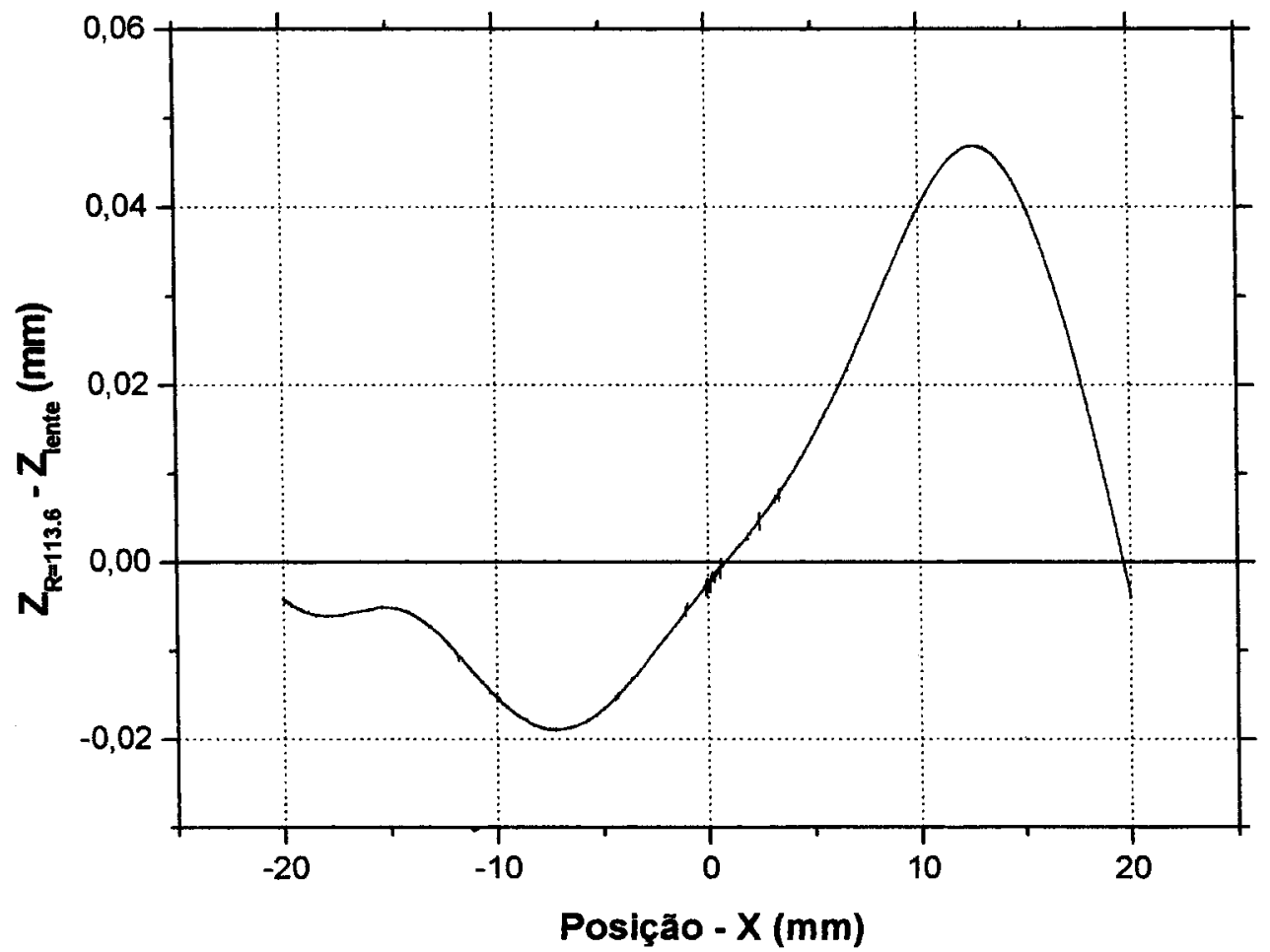

Figura 7.23 - Diferença entre perfil com $R=113,6 \mathrm{~mm}$ e o perfil longitudinal da face superior da lente de PS.

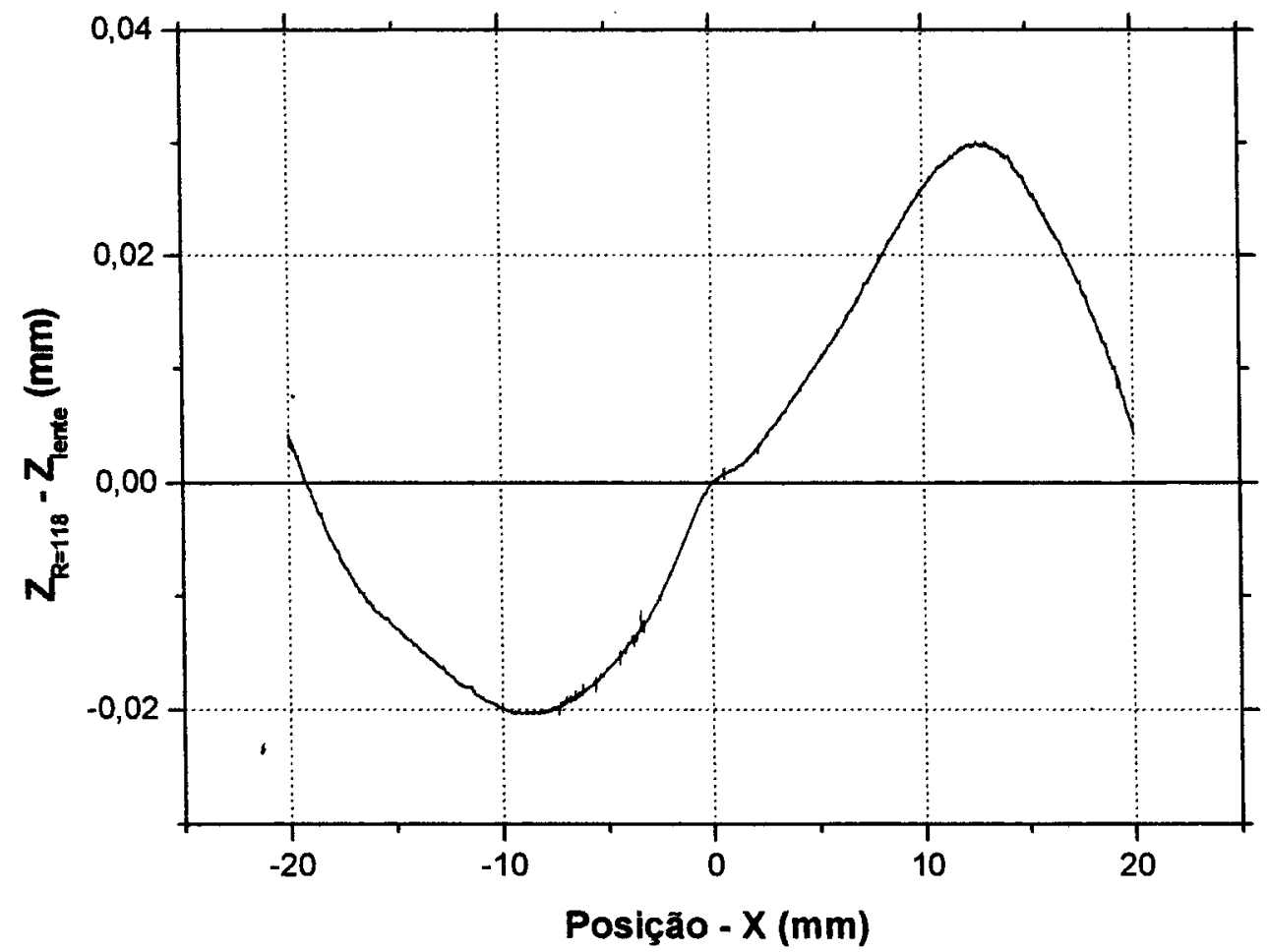

Figura 7.24 - Diferença entre perfil com $R=118 \mathrm{~mm}$ e o perfil longitudinal da face inferior da lente de PS. 


\section{8 - Medidas de Planicidade dos Perfis Circulares da Lente}

\subsection{1 - Introdução}

Este estudo foi realizado após a constatação de que as lentes apresentavam deformações e que essas deformações eram desiguais entre os perfis longitudinal e transversal. O objetivo deste estudo foi, então, verificar se existe algum tipo de padrão na deformação ocorrida devido à contração do material durante o resfriamento da lente.

Para realização dessas medidas, utilizou-se o equipamento para aferição de perfis circulares TALYROND 250, fabricado pela TAYLOR-HOBSON. As medidas de planicidade dos perfis circulares referem-se a medidas realizadas conforme o esquema proposto na figura 7.25 e descrito a seguir:

1. A base giratória, onde está fixado o objeto cuja superfície se deseja medir, gira ao redor de seu próprio eixo; .

2. O sensor pode ser deslocado desde o centro do disco até sua extremidade;

3. Através de deslocamentos consecutivos acompanhados do giro da base giratória, mede-se a planicidade das linhas definidas pelos anéis concêntricos definidos pelo ponto de contato do sensor com a superfície;

4. Cada deslocamento do braço, que suporta o sensor resulta em uma medida de planicidade cujo resultado é apresentado, conforme demonstrado na figura 7.28.

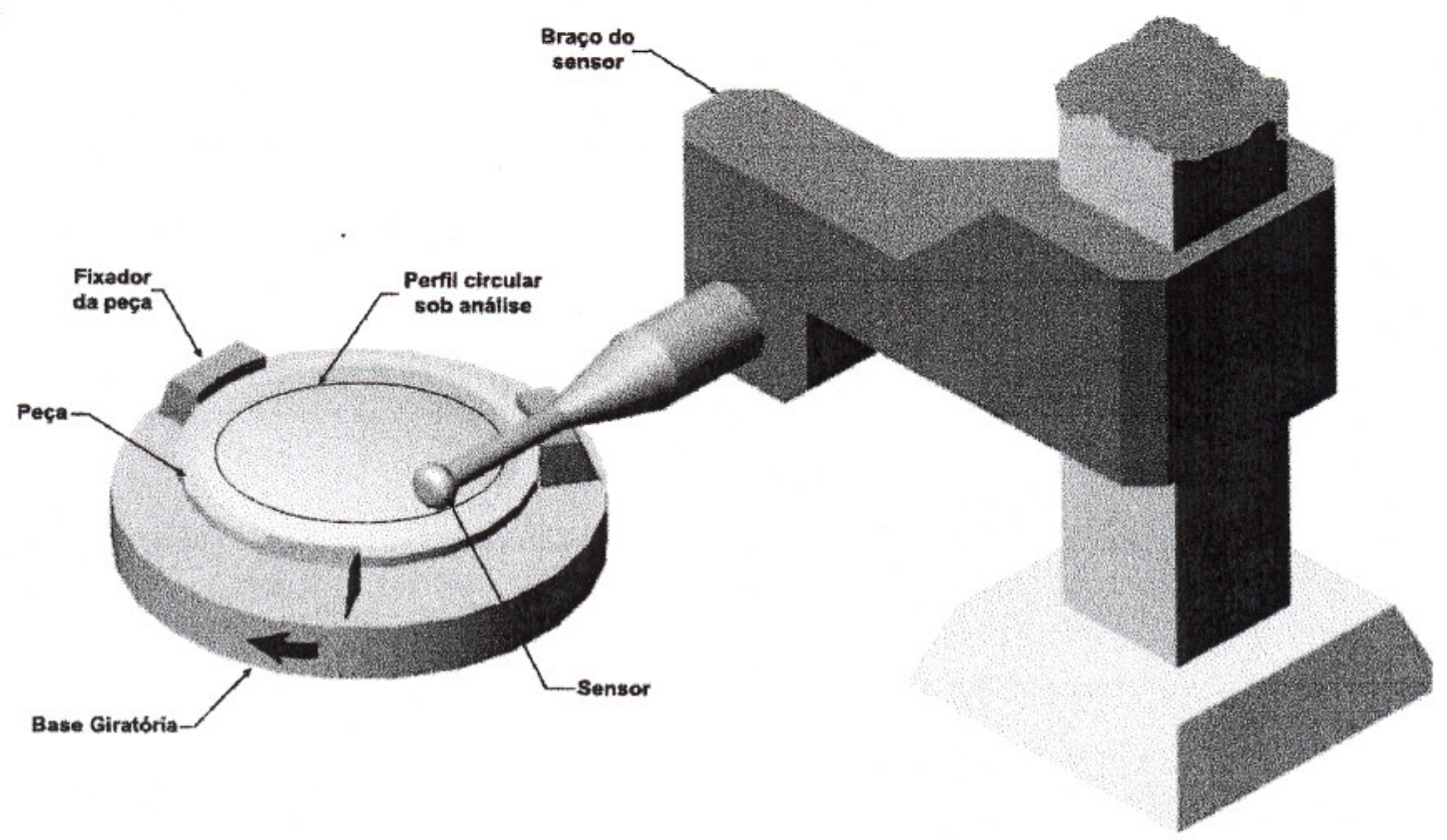

Figura 7.25 - Esquema do dispositivo de medida de planicidade. 
Para compreender os resultados obtidos algumas definições são necessárias:

Planicidade (símbolo: $\square$ )

A definição mais clara da medida de planicidade (Flatness), faz-se através da figura 7.26. Como pode ser observado, planicidade é a distância entre as duas linhas paralelas à linha de referência as quais delimitam a máxima e mínima amplitude da superfície medida.

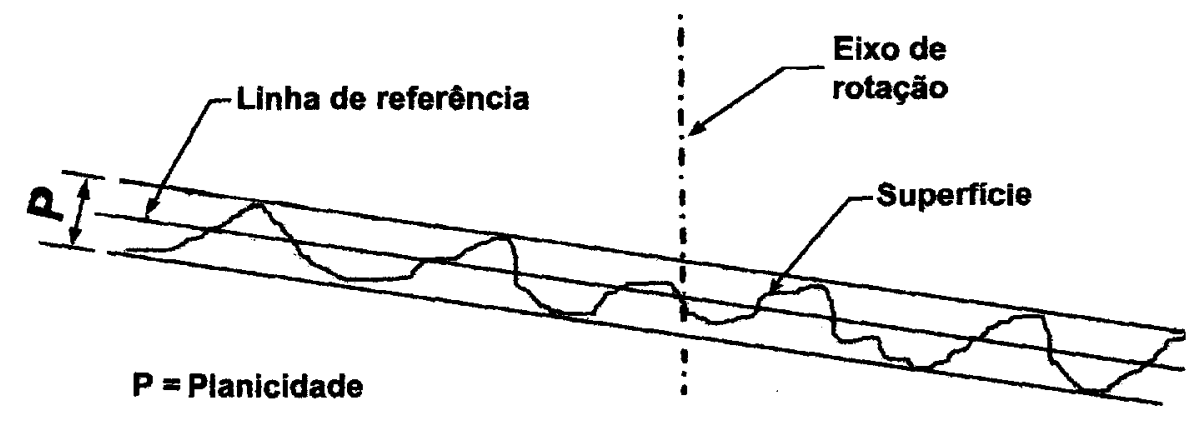

Figura 7.26 - Definição da medida de planicidade.

\section{Círculo dos Mínimos Quadrados (LS)}

O círculo dos mínimos quadrados (Least Square circle-LS) é calculado para se ajustar aos dados de forma que a soma dos quadrados dos desvios externos e internos ao círculo seja mínima. A figura 7.27 auxilia no entendimento do significado dessa definição.

\section{Ângulo (símbolo: $<$ )}

Como pode ser observado na figura 7.27, o ângulo apresentado como resultado é aquele resultante entre a linha que une o centro do círculo de referência (LS) ao centro de rotação da base giratória e a linha que serve de referência para o equipamento. Para as medidas realizadas, o ângulo mede então a variação da posição do centro da superfície medida com relação ao centro da base giratória.

Raio (R)

$\mathrm{O}$ raio $R$ determina a distância do sensor ao centro da base giratória.

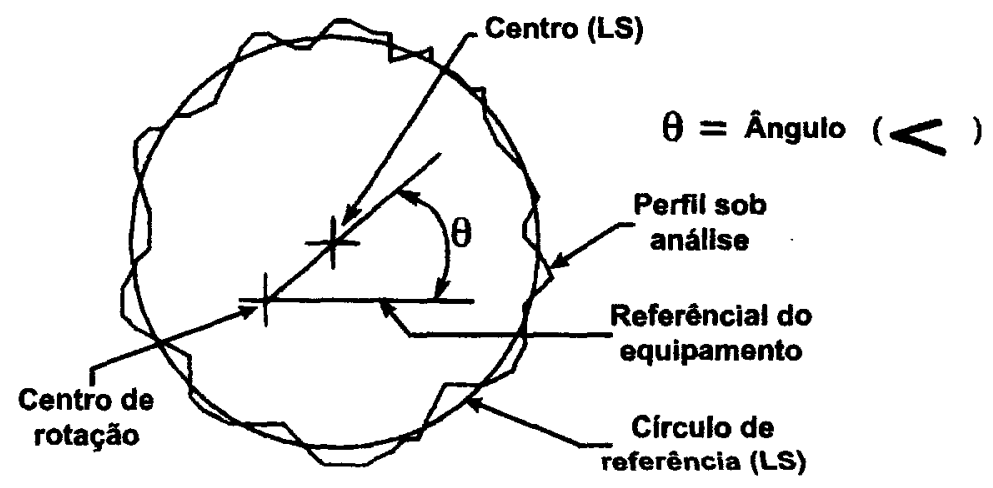

Figura 7.27 - Definição do centro de referência (LS) e do ângulo. 


\subsection{2 - Resultados}

Foram realizadas medidas de planicidade para ambos os lados da lente, desde o centro até o raio de $24 \mathrm{~mm}$ com espaçamentos de aproximadamente $1 \mathrm{~mm}$ entre medidas. Dessa forma, delineou-se quase que totalmente o perfil da lente pois, para regiões próximas, não existe variação significativa.

O equipamento não fornece um conjunto de pontos, com coordenadas que permitam a reprodução do perfil medido em gráficos. O resultado para cada uma dessas medidas é apresentado pelo equipamento de medida na tela do computador como exemplificado na figura 7.28, não tendo portanto, uma resolução muito satisfatória. Como se observa na figura, os resultados numéricos da planicidade e do ângulo são acompanhados da representação gráfica da superfície medida. Nessa representação, a curva fechada que se auto-intersecta em alguns pontos, representa todo o perfil medido. A condição ideal para essa curva seria a apresentação de uma linha reta, sem oscilações, indicando que todo os pontos da circunferência medida, sobrepõem-se o que indicaria por sua vez a existência de uma superficie totalmente plana.

\begin{tabular}{|llllll}
\hline RTH & TR250 & Fank & Taylor & Hobson & Lta \\
\hline
\end{tabular}

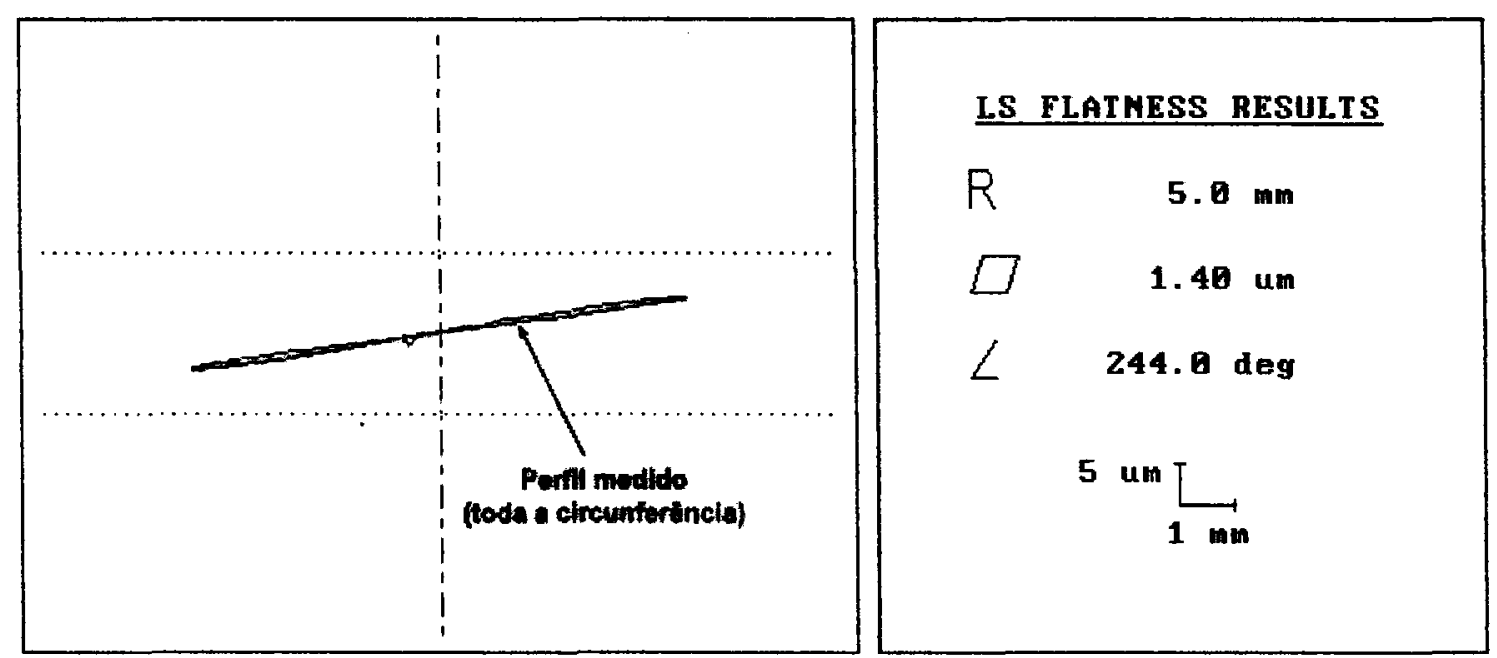

Figura 7.28 - Amostra do resultado apresentado para medidas de planicidade

Uma represéntação gráfica de todas as medidas obtidas é apresentada na figura $7.29 \mathrm{e}$ algumas figuras que sejam relevantes para visualização da deformação presente na superfície da lente são, também, apresentadas.

O gráfico apresentado na figura 7.29 permite observar alguns detalhes sobre a deformação da superfície de ambos os lados da lente:

- A deformação de ambas as superfícies aumenta do centro para a extremidade; 
- A partir do centro e em direção à borda, a face superior apresenta-se deformada mas com um padrão crescente e quase linear no nível de deformação;

- Diferentemente da face superior, a face inferior apresenta oscilações no nível de deformação do centro para a extremidade;

- Na face inferior, os picos de alteração na planicidade são devidos a imperfeições da cavidade, que resultaram em pontos com relevo bastante alterado nessa face da lente.

A variação dos valores obtidos para os ângulos indica que os centros dos perfís analisados não concordam com o centro da borda da lente, que foi utilizada para fixá-la ao equipamento. Por outro lado, o fato desses valores oscilarem entre valores próximos indica que apesar dos centros dos círculos de referência (LS) variarem, ainda assim, existe certa simetria para a deformação das superfícies. Essa simetria é mais acentuada para o perfil da face superior da lente, como já foi identificado no mapeamento descrito no item 7.7.

É possível observar que as amplitudes de deformação da superfície não se apresentam todas ao longo de uma única linha do centro até a borda, ao contrário disso, observa-se que enquanto nas figuras 7.30 e 7.31 os picos de deformação situam-se próximos ao eixo central; na figura 7.32, a posição da amplitude máxima desloca-se dessa região.

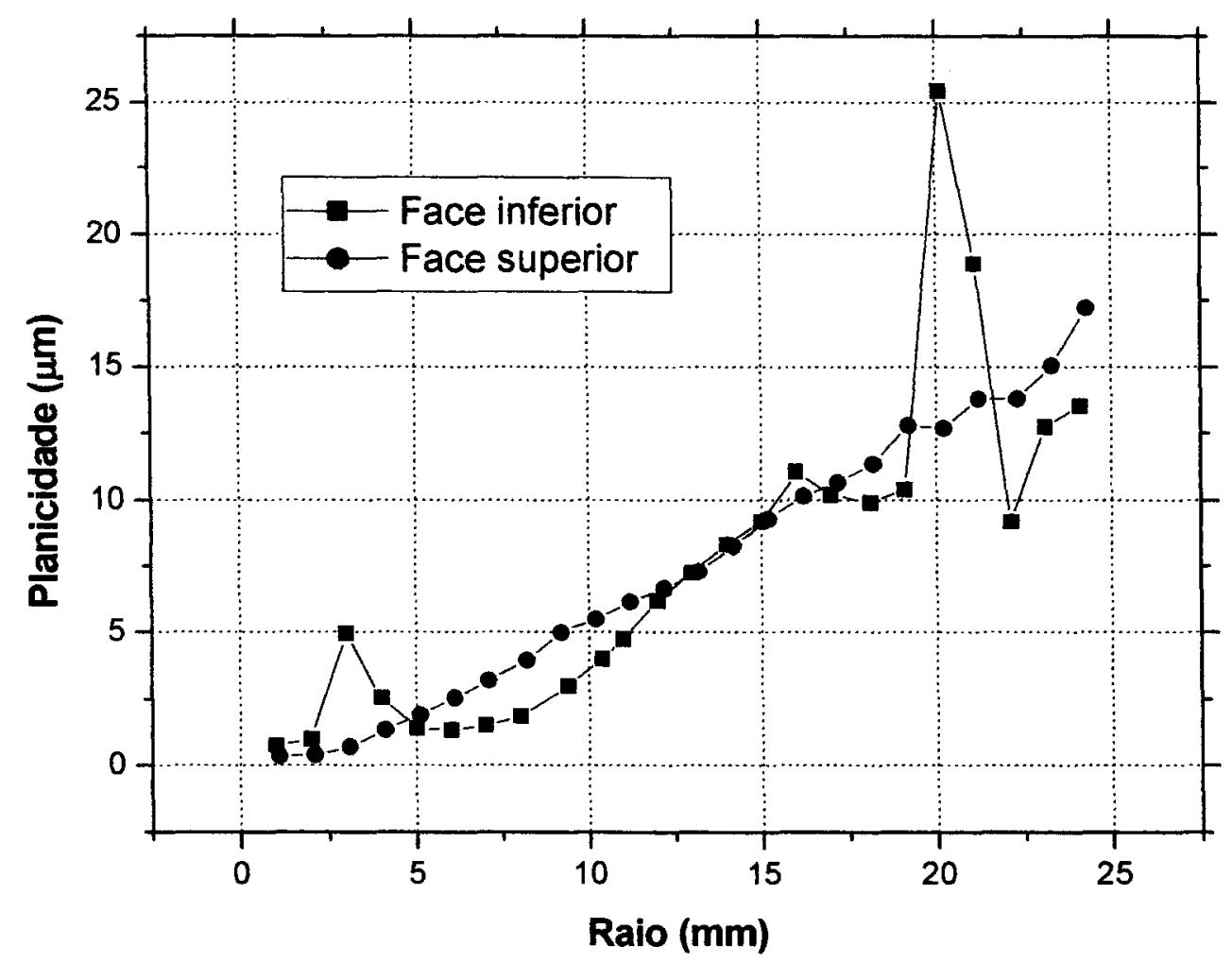

Figura 7.29 - Gráfico da planicidade associada à posição para face inferior e superior da lente. 
As figuras 7.33, 7.34 e 7.35 são exemplos dos resultados obtidos para a face superior da lente. Essas figuras comprovam, mais uma vez, que apesar da face superior da lente apresentar níveis máximos de deformação similares àqueles apresentados pela face inferior, a transição entre as deformações do perfil de uma região para outra não ocorre de forma brusca. Esse padrão de deformação faz com que essa superfície seja aparentemente melhor que a da face inferior, quando a análise é visual.

Diante dos resultados apresentados, fica evidente que tentativas posteriores de melhoria do processo de injeção de lentes devem ser acompanhadas por análises semelhantes às que foram descritas nesse capítulo.

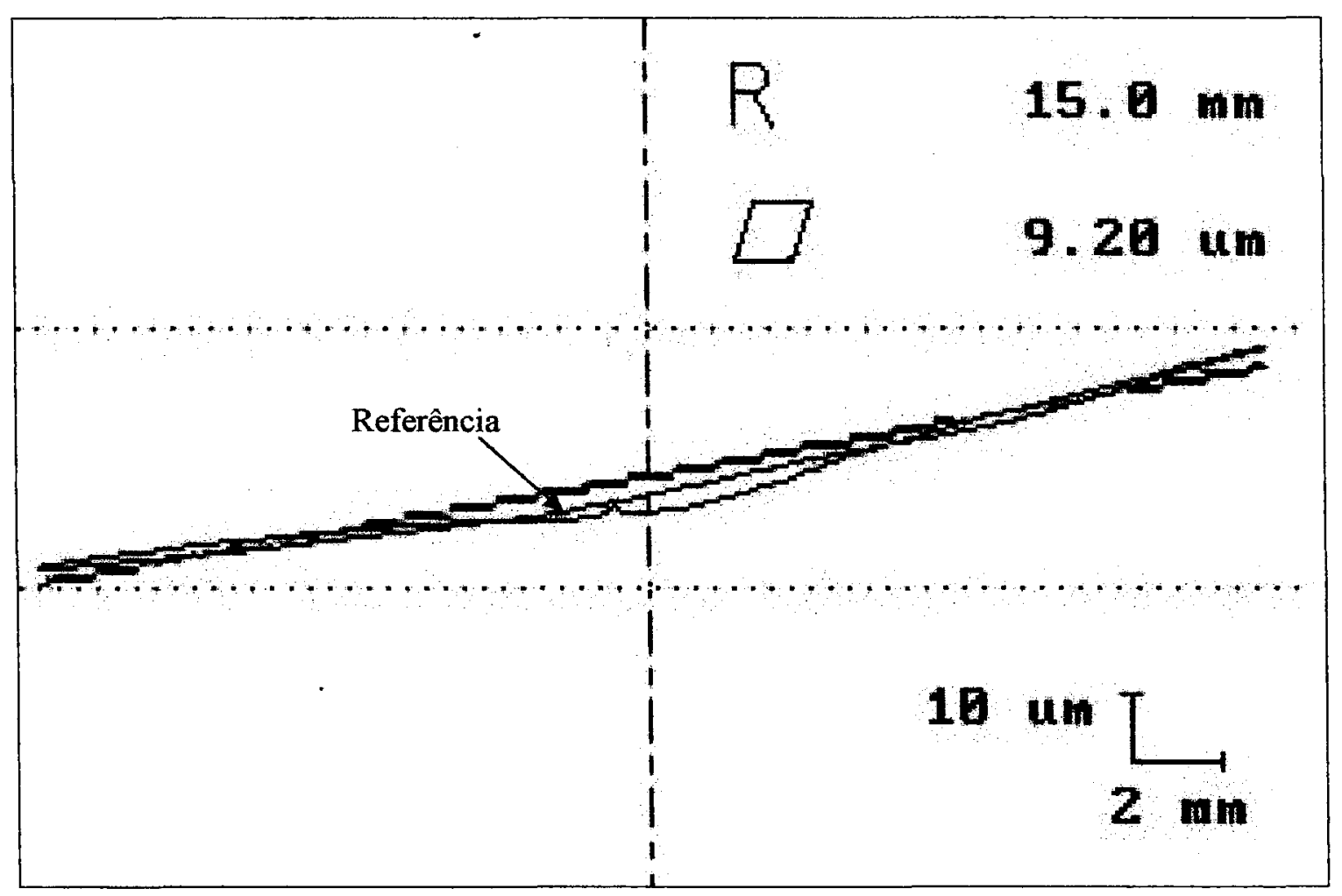

Figura 7.30 - Representação do perfil da face inferior para $R=15 \mathrm{~mm}$. 


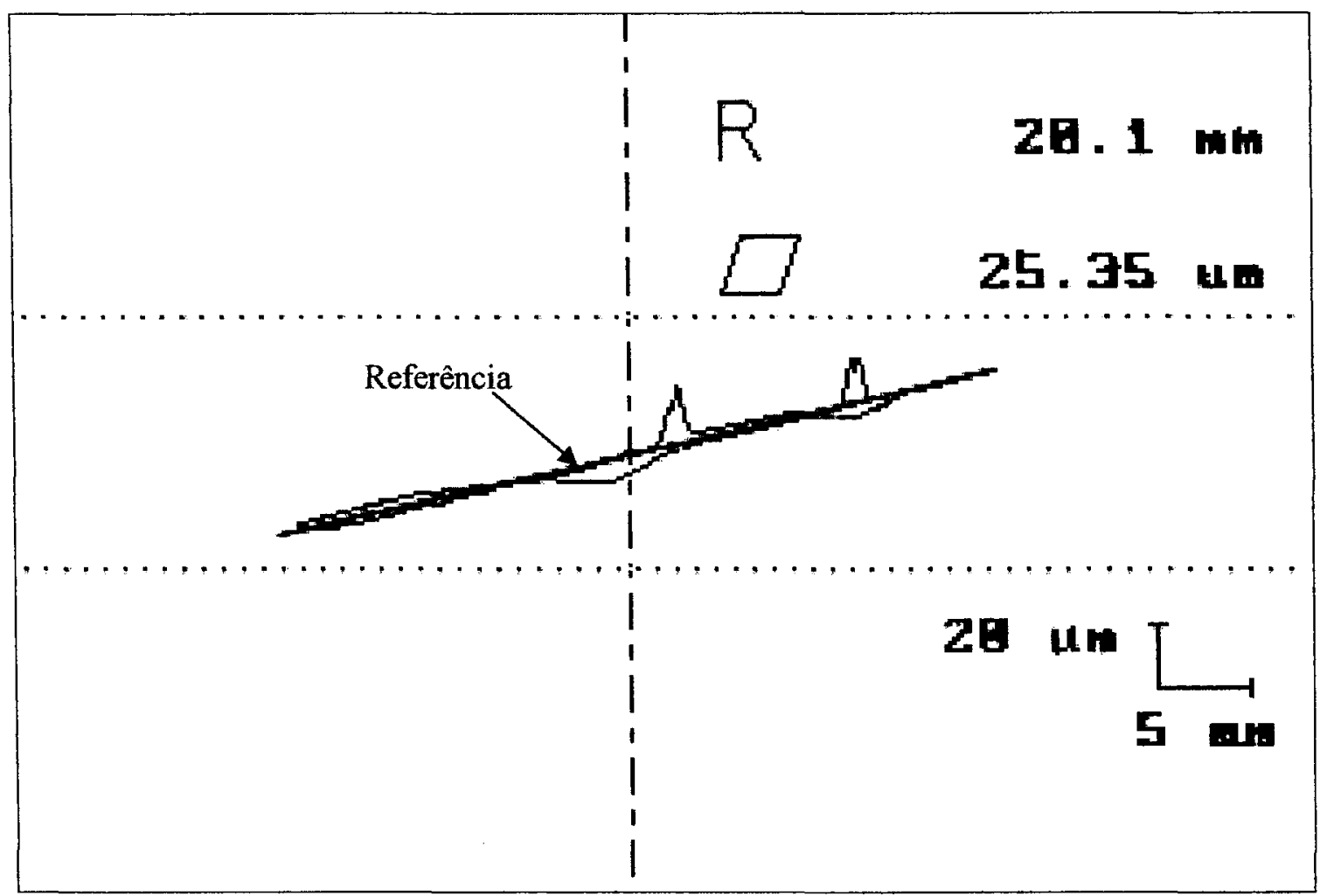

Figura 7.31 - Representação do perfil da face inferior para $\mathrm{R}=20,1 \mathrm{~mm}$.

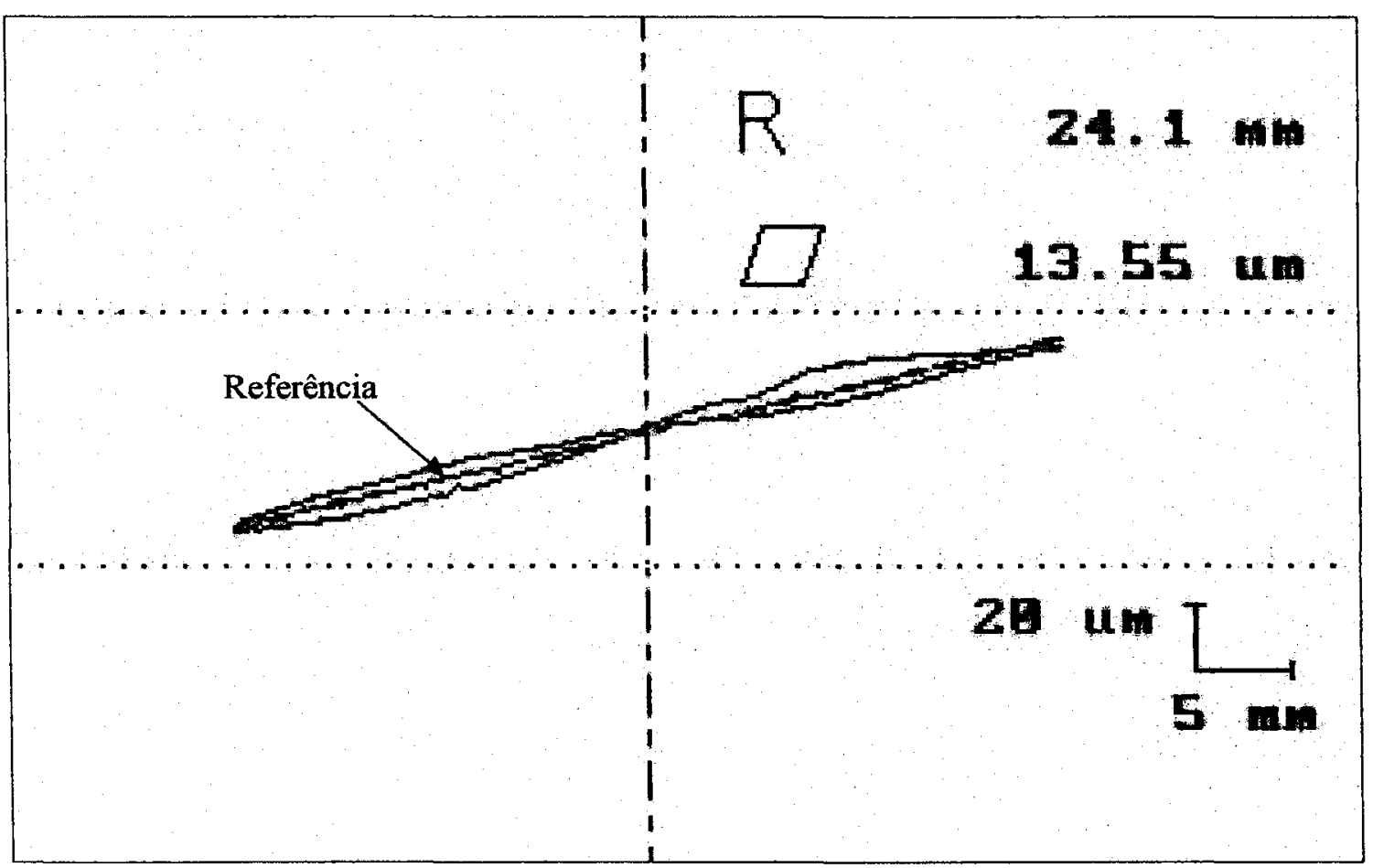

Figura 7.32 - Representação do perfil da face inferior para $\mathrm{R}=24,1 \mathrm{~mm}$. 


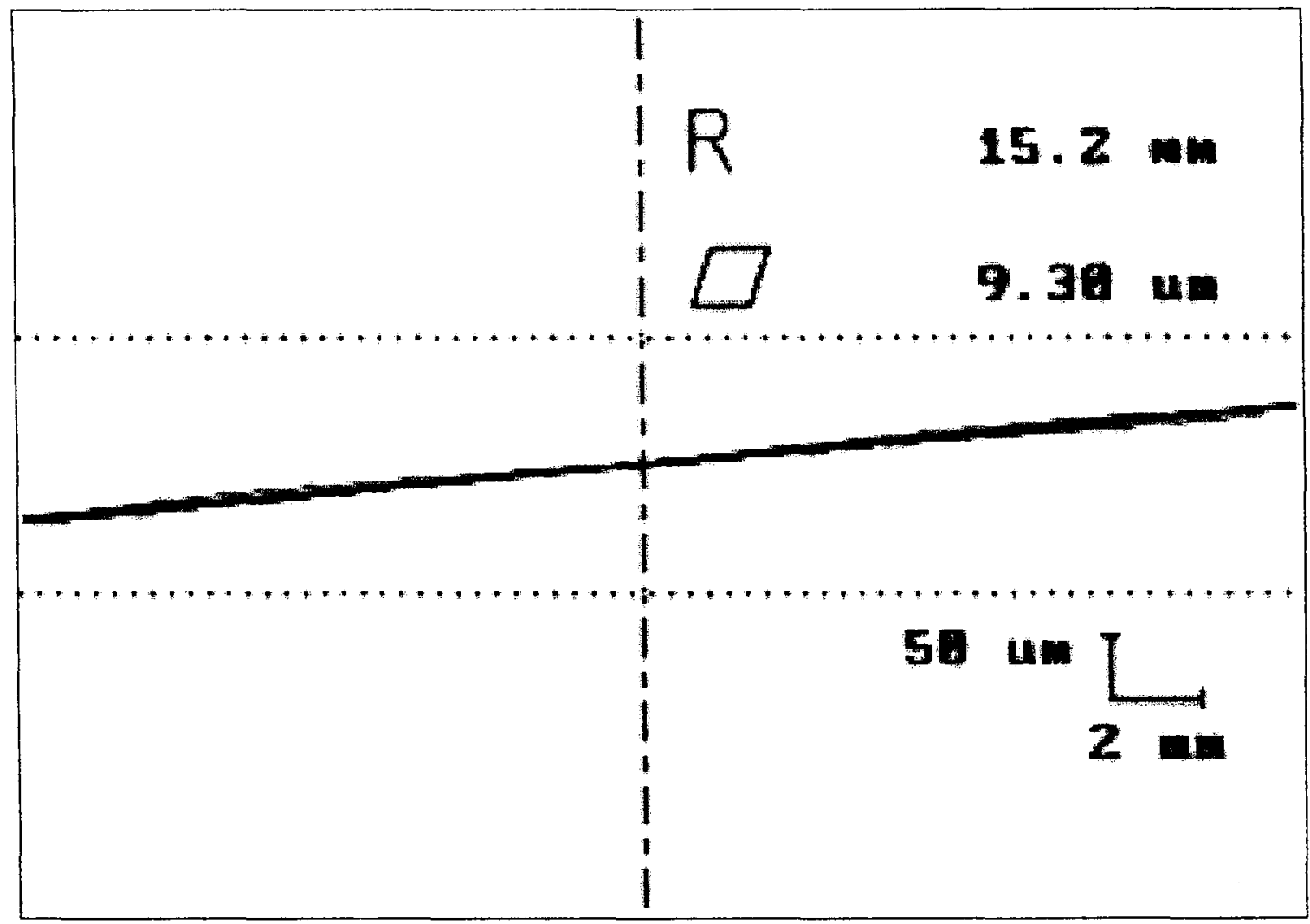

Figura 7.33- Representação do perfil da face superior para $R=15,2 \mathrm{~mm}$.

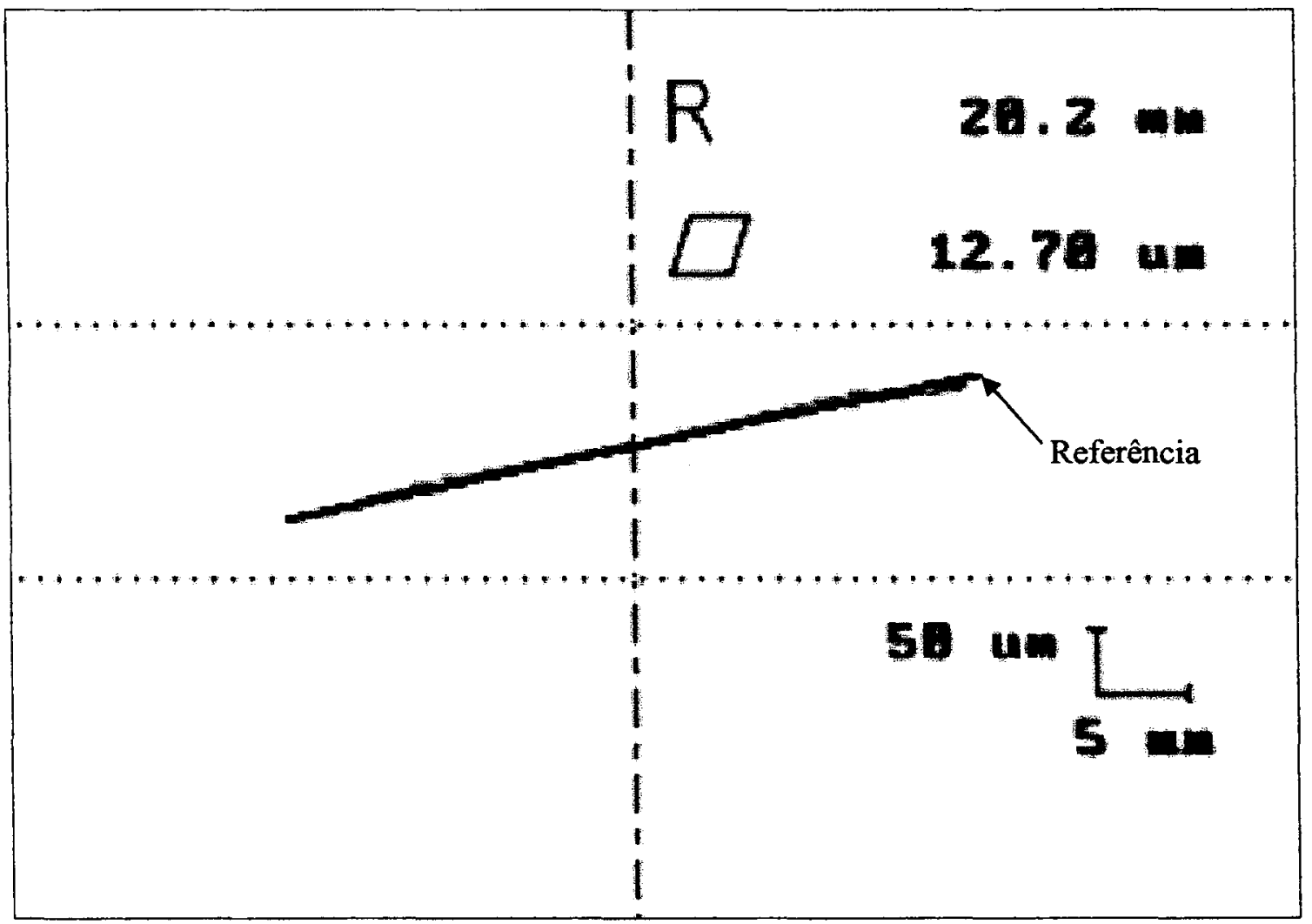

Figura 7.34 - Representação do perfil da face superior para $\mathrm{R}=20,2 \mathrm{~mm}$. 


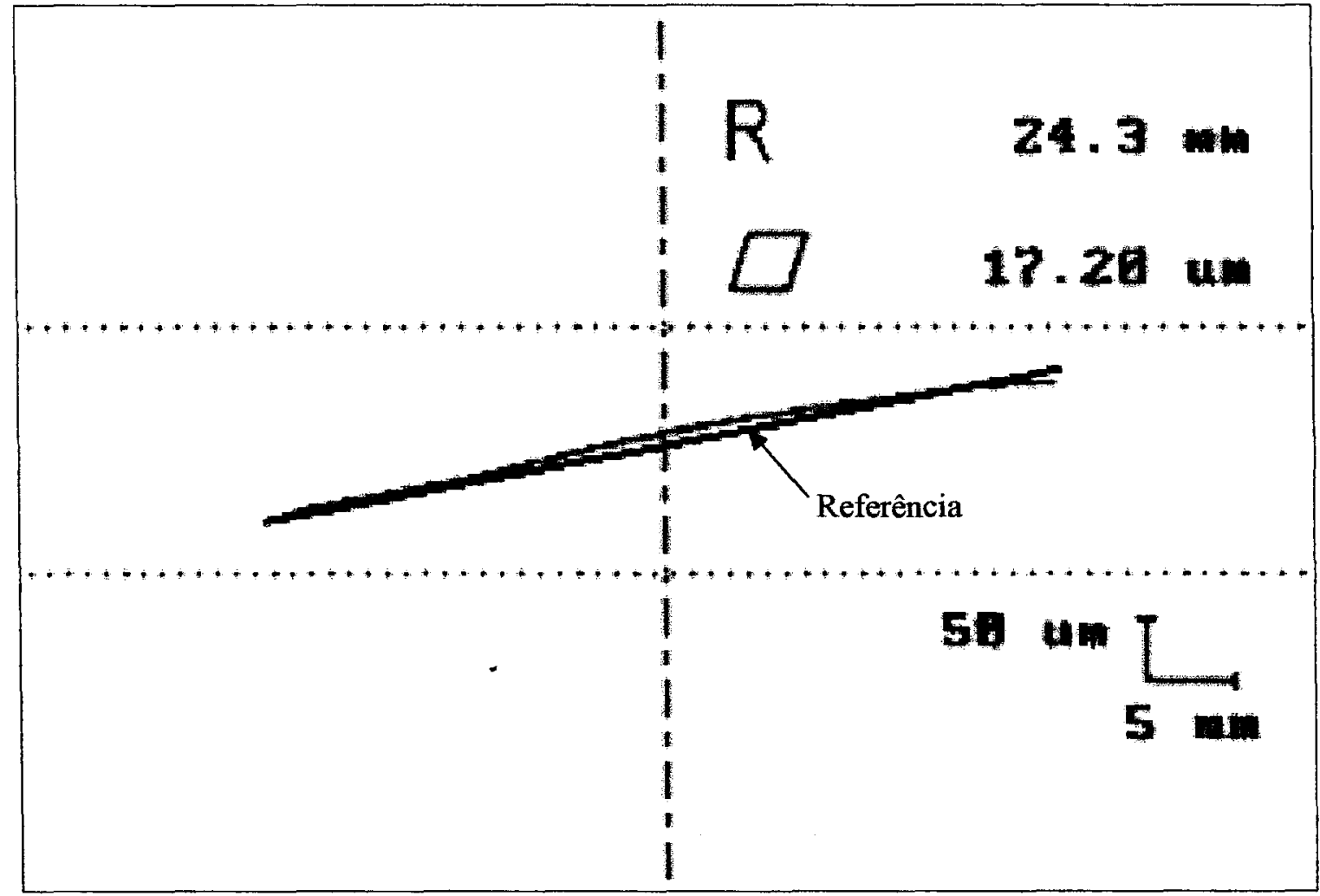

Figura 7.35 - Representação do perfil da face superior para $R=24,3 \mathrm{~mm}$. 


\section{8 - CONCLUSÃO}

O objetivo desse trabalho foi o de produzir lentes acrílicas de baixo custo para utilização no Ensino Fundamental e Médio. Dessa forma, esse trabalho está inserido no programa de produção de material didático que é desenvolvido pelo Centro de Divulgação Cientifica e Cultural da USP, que procura utilizar os recursos do processo de injeção de termoplásticos para produzir kits educacionais de baixo custo, possibilitando uma maior difusão desse tipo de material para utilização no ensino de Ciências.

Durante a execução do projeto foram encontrados alguns obstáculos, principalmente devido à deficiência da estrutura existente nas oficinas mecânicas do CDCC e do IFSC para a confecção de moldes para injeção de termoplásticos. Devido a essa deficiência, algumas partes do molde foram feitas em empresas especializadas, encarecendo os custos de desenvolvimento do projeto. Esse trabalho foi pioneiro em dois aspectos: a fabricação e caracterização de elementos ópticos injetados e a fabricação e utilização de moldes para injeção de termoplásticos para produção de componentes de qualidade.

O ganho mais significativo com esse projeto foi a experiência adquirida, que pode permitir melhorias significativas em trabalhos futuros. Como exemplo dessas melhorias, pode-se citar a elaboração de um molde que possua um dispositivo de compressão; um sistema hidráulico ou mecânico eletronicamente controlado, que possa, no momento exato, comprimir a massa de material fundido em fase de solidificação. Um dispositivo como esse, poderia eliminar totalmente a deformação decorrente da contração do material e a lente apresentaria qualidade muito superior àquela obtida pelo processo atual. Tal dispositivo seria realmente inovador para o processo de fabricação de lentes. Com o mesmo enfoque, seria também interessante explorar o processo de injeção-compressão descrito no item 3.6.

Além do dispositivo citado acima, outra alteração que poderia trazer bons resultados para o processo é a utilização de um bico valvulado para controlar a entrada de material na cavidade, evitando dessa forma, o surgimento do "fio", como foi descrito no capítulo 6.2 e assim aumentando o range de temperaturas utilizadas.

Apesar da qualidade óptica das lentes obtidas ser inferior à das lentes fabricadas pelo processo de termo-moldagem ou em vidro polido, como pode ser constatado no item 7.4.1, os custos relacionados, que resultam em um valor muito pequeno para cada lente injetada, justificam a busca por otimização do processo. Uma comparação entre os custos de fabricação e produtividade de cada processo pode ser encontrada no apêndice II. É claro que a introdução do dispositivo de compressão e do bico valvulado, citados anteriormente, resultaria em investimentos adicionais. No entanto, a alta produtividade do processo poderia compensar esses custos. 
As diferenças observadas nos perfis da lente com relação à cavidade merecem atenção especial. Apesar de ser constatado que os perfis da cavidade apresentam-se asféricos, esse é o menor dos problemas para o processo. A solução desse problema consiste no aperfeiçoamento do processo de polimento de perfis esféricos metálicos. Esse processo de polimento deve ser acompanhado de verificações freqüentes do perfil. Mais importante é a diferença entre os perfis da lente e da cavidade. Tais diferenças poderiam ser utilizadas para modelar a cavidade de forma a compensar a deformação. A constatação de que a zona do "gate" é diferente do restante do perfil, pode indicar a necessidade de pontos adicionais para a entrada de material na cavidade. Dessa forma, ter-se-ia maiores chances de compensar a perda de definição do perfil devido à contração.

A medida de FTM mostrou-se valiosa na qualificação das lentes produzidas e qualquer trabalho futuro que busque melhorar a qualidade das lentes pelo processo de injeção, deve-se valer de tal análise, pois, acredita-se que o nível máximo de qualidade que pode ser avaliado de forma visual foi atingido e, acima disso, começa-se a entrar no campo da análise subjetiva e passível de erros do avaliador. Além da medida de FTM, outra análise muito importante que deve ser efetuada para otimização do processo é a medida da deformação descrita nos itens 7.7 e 7.8 .

Diferentemente da confecção de elementos fabricados em vidro polido, a fabricação de lentes injetadas impõe dificuldades adicionais, porque se uma lente apresenta o resultado diferente daquele desejado, pode ser necessário alterar partes do molde, algo que nem sempre é simples e que pode resultar em gastos de tempo e recursos financeiros, quando se recorre à prestação de serviço de empresas especializadas. Existe, também, o fato de que essas empresas nem sempre atendem totalmente às especificações solicitadas para a construção do molde por julgá-las desnecessárias ou dificultosas na fabricação. Assim, seria interessante para futuros trabalhos nessa área, que equipamentos adequados fossem adquiridos e que técnicos fossem treinados para essa especialidade.

A busca pela otimização do processo de injeção para obtenção de lentes com maior qualidade esbarrou na incapacidade da máquina injetora em proporcionar maiores pressões de injeção. Os ajustes contínuos efetuados durante os testes de injeção permitiram estabelecer a pressão de injeção ‘como o principal parâmetro responsável pela qualidade das lentes no quesito deformação. Sem maiores pressões de injeção, que trazem associadas maiores pressões de recalque, é impossível obter lentes em melhores condições do que as obtidas. Isso também pode ser constatado em Lu e Khim (2001), onde pressões de até 1560 bar foram utilizadas para injeção de lentes em policarbonato, que apresentam espessura média menor que as lentes produzidas durante esse trabalho. 
Lentes com menor variação em espessura apresentam conseqüentemente menores níveis de contração em valores absolutos e, assim, podem ser esperados melhores resultados se forem considerados variações no desenho de lentes, que apresentem menor diâmetro e/ou maior raio de curvatura que as lentes produzidas.

O objetivo desse trabalho foi explorar uma alternativa para a confecção de elementos ópticos. Apesar das lentes obtidas no final do processo não apresentarem um nível de qualidade tão alto quanto àquelas fabricadas em vidro pelo IFSC, elas se prestam muito bem para aplicações no Ensino Médio, seja no ensino de óptica geométrica ou em aulas de Ciências para análise de espécimes de tamanho reduzido. Deve-se salientar, ainda, que as medidas de FTM realizadas com lentes comerciais de baixo custo encontradas no mercado apresentaram valores muito próximos ao das lentes produzidas nesse trabalho. Algumas lentes em vidro polido apresentaram inclusive níveis de qualidade abaixo das lentes injetadas. Isso se torna mais marcante, quando se comparam os custos dessas lentes.

As lentes produzidas estão sendo utilizadas por alunos do ensino fundamental como instrumento (lupa) para observação de pequenos insetos. O baixo custo do processo permite que cada aluno tenha a sua própria lupa.

O processo utilizado apresenta grande quantidade de variáveis dificeis de serem controladas e, mesmo assim, o resultado final foi condizente com os objetivos propostos, ou seja, uma lente injetada em acrílico foi produzida e caracterizada e essa lente é adequada para a utilização no Ensino Médio e Fundamental. 


\section{9 - BIBLIOGRAFIA}

CRUZ, Renato Antonio. Confecção de lentes acrílicas para o ensino de óptica. São Carlos, 1997. 65p. Tese (Mestrado) - Instituto de Física de São Carlos, USP.

DYM, Josefh B. Injection Molds and Molding. ed. 2. Chapman \& Hall. New York. 1987.

HORNE, D. F. Optical Production Technology. Bristol Adam Hilger. 1983.

HORNE, D. F. Spectable Lens Tecnology. Bristol Adam Hilger. 1978.

LU, X.; KHIM, L.S. A statistical experimental study of the injection molding of optical lenses. Journal of Material Processing Technology 113. Elsevier. 2001.

MEETEN, G. H. Optical Properties of Polymers. London Elsevier Applied Science. 1986.

METACRIL Literatura Técnica do Polimetacrilato de Metila. 2001

REVISTA PLÁSTICO INDUSTRIAL. Rio de Janeiro, Fev. 2001

RUBIN, Irvin I. Injection Molding Theory and Pratice. John Wiley \& Sons, Inc. 1972.

SILVA, A. R.; Marega, E. Desenvolvimento de moldes para a confecção de lentes de acrílico. In: VI Simpósio de Iniciação Científica da Universidade de São Paulo, São Carlos, 1998.

SMITH, Warren J. Modern Optical Engineering. McGraw - Hill Book Company. New York, 1966.

SORS, L.; Bardócz, L.; Radnóti, I. Plásticos, Moldes \& Matrizes. Ed. Hemus. São Paulo. /197?/.

TWYMAN, F. Prism and Lens Making - A Textbook for Optical Glassworkers. Bristol Adam Hilger. 1988.

U.S, Precision Lens The Handbook of Plastic Optics. ed. 2. Cincinnati, Ohio. 1983.

YASUOKA, Fátima M. M. Técnicas de Desenho Óptico e Avaliação da Qualidade de Imagem em Sistemas Ópticos por Medição de Função de Transferência Óptica. São Carlos, 1997. 239p. Tese (Doutorado) - Instituto de Física de São Carlos, USP. 


\section{APÊNDICE I}

\section{O Processo de Fabricação de Lentes por Termo-Moldagem}

O processo de termo-moldagem, desenvolvido pelo CDCC, consiste na utilização da prensa apresentada na figura A1 e de um molde construído de acordo com a figura A2. Esse molde é montado de forma que a parte inferior é fixada À base da prensa e a parte superior acompanha o movimento do pistão hidráulico. O sistema é composto ainda por uma estufa para amolecimento dos discos de acrílico e por uma bomba de vácuo, que elimina o ar do interior da cavidade, evitando o surgimento de bolhas nas lentes produzidas.

O processo de moldagem é executado da seguinte forma:

a) Corte de placas de acrílico comercial em quadrados de tamanho adequado;

b) Corte das arestas dos quadrados, formando octógonos;

c) Torneamento dos octógonos resultando em discos de diâmetro adequado à lente que se deseja produzir;

d) Colocação dos discos na estufa para amolecimento;

e) Colocação dos discos amolecidos sobre o inserto inferior com o molde aberto;

f) Fechamento parcial do molde e acionamento da bomba de vácuo;

g) Prensagem do disco;

h) Resfriamento da lente;

i) Abertura e retirada da lente produzida.

A troca dos insertos permite que se reutilize todo o equipamento na confecção de lentes com os mais variados perfis, desde que seja mantido o diâmetro mais externo, que corresponde ao diâmetro interno do anel de centragem.

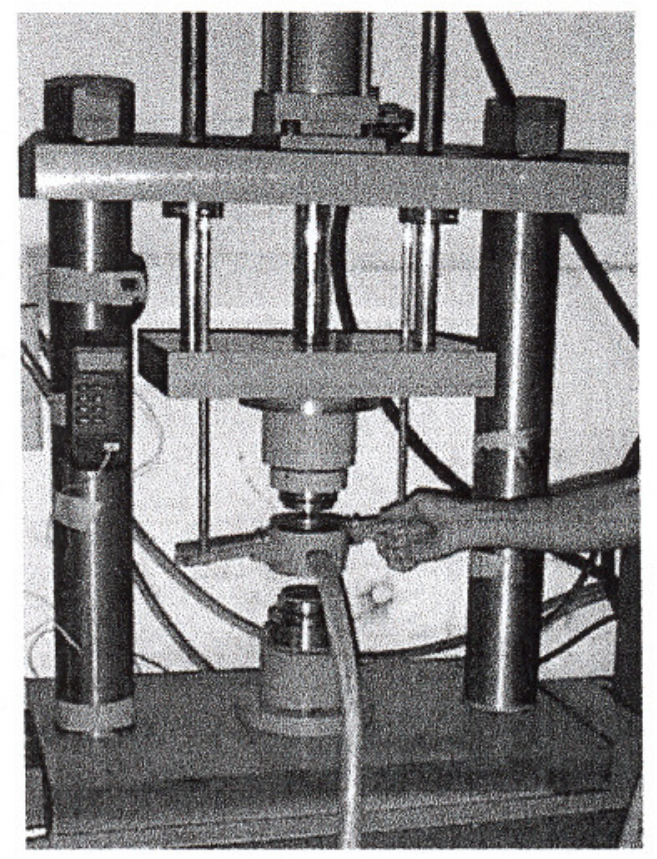

Figura A1 - Fotografia da montagem do molde para termo-moldagem na prensa. 


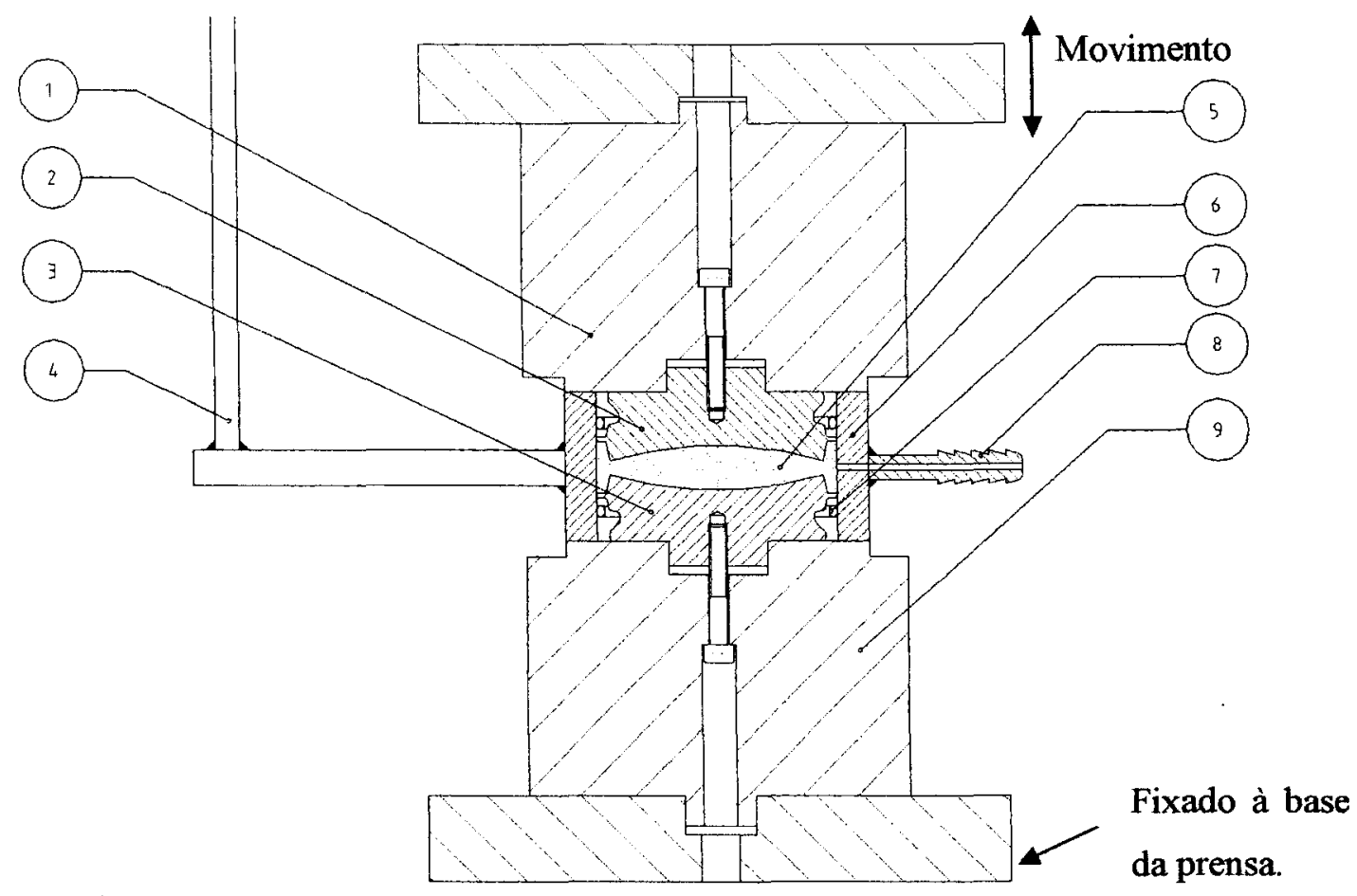

Legenda:

1- Base do inserto superior. 5- Lente moldada.

2- Inserto superior. 6- Anel de centragem.

3- Inserto inferior. 7- Anel de vedação (o'ring).

4- Haste do anel de 8- Engate para sucção de ar. centragem. 9 9- Base do inserto inferior.

Figura A2 - Desenho do molde para termo-moldagem.

Uma das características indesejáveis desse processo é o alto nível de tensionamento, que surge nas lentes produzidas devido às dificuldades de escoamento do material amolecido para conformar o perfil da cavidade. Se a temperatura do material for elevada, $o$ tensionamento diminui, mas observa-se o surgimento de grande número de bolhas na superfície da lente devido à degradação provocada pela queima do material. Esse tensionamento provoca o surgimento do fenômeno de birrefrigência, que pode ser observado na figura $\mathrm{A3}$, na qual a fotografia foi obtida com o mesmo procedimento citado no item 7.4.

Outra desvantagem é a relativa complexidade que envolve o corte da placa, torneamento com precisão razoável e aquecimento em estufa. Isso ocasiona aumento significativo do tempo gasto para produção das lentes. O próprio processo de prensagem do material aquecido, que compreende um ciclo total de aproximadamente 5 minutos por lente, também é demorado. Tudo isso contribui para aumento dos custos de fabricação de lentes por esse método. 
Em contrapartida, é um processo de obtenção de lentes muito interessante, quando se consideram o tempo de fabricação e o custo de uma lente de vidro.

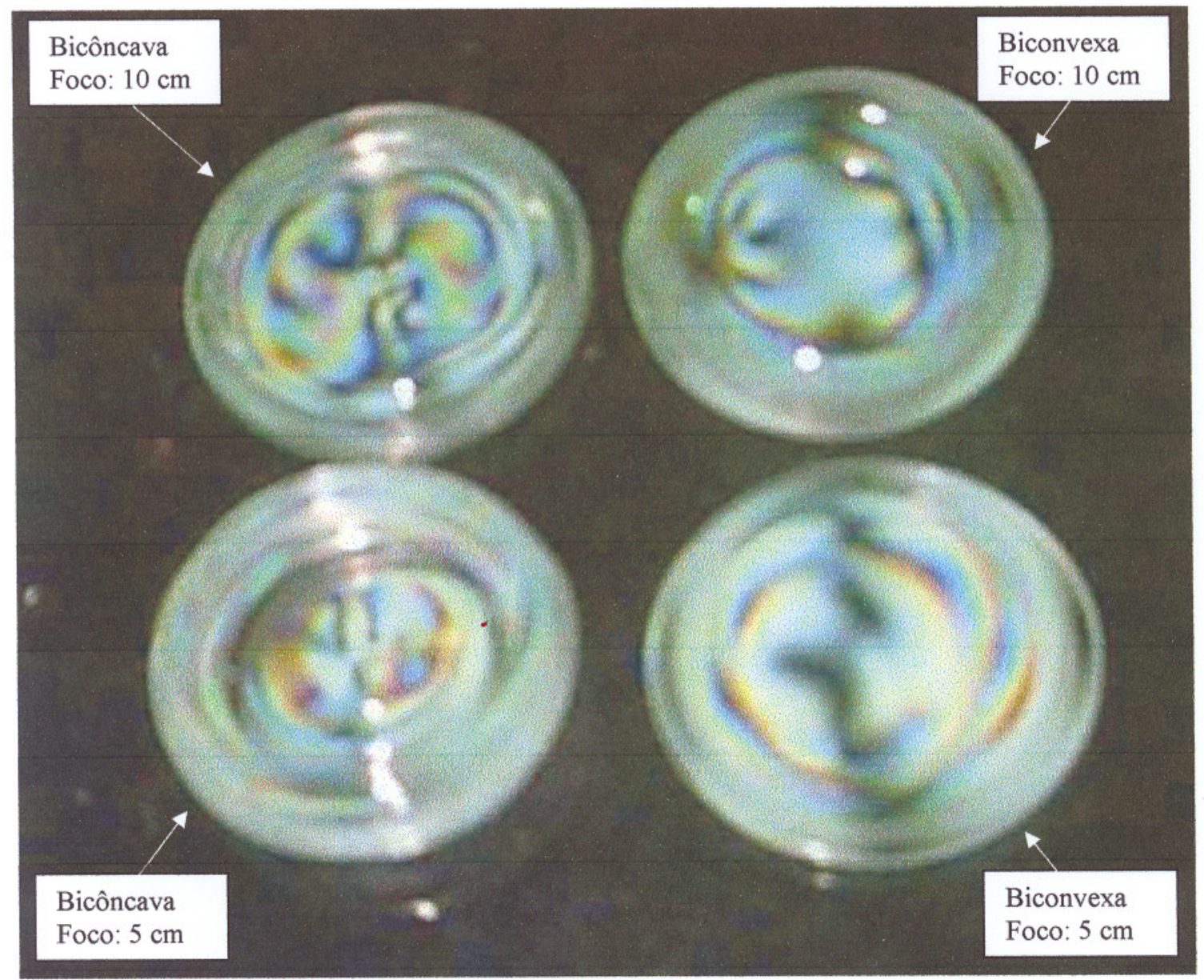

Figura A3 - Análise de birrefrigência das lentes termo-moldadas. 


\section{APÊNDICE II}

\section{Comparação entre Processos de Fabricação de Lentes}

Tabela A1 - Valores envolvidos nos vários processos de fabricação de lentes.

\begin{tabular}{|l|c|c|c|c|}
\hline Processo e material & $\begin{array}{c}\text { Ciclo } \\
\text { (min./unidade) }\end{array}$ & $\begin{array}{c}\text { Produçáo } \\
\text { (unidades/mes) }\end{array}$ & $\begin{array}{c}\text { Custo por } \\
\text { unidade (USS) }\end{array}$ & $\begin{array}{c}\text { Investimento } \\
\text { (USS) }\end{array}$ \\
\hline Injeção de acrílico & 0,375 & 87.360 & 0,13 & $56.000,00$ \\
\hline $\begin{array}{l}\text { Termo-moldagem de } \\
\text { acrílico (Cruz, 1997) }\end{array}$ & 5 & 6.552 & 1,70 & $8.500,00$ \\
\hline $\begin{array}{l}\text { Polimento de vidro } \\
\text { comum }\end{array}$ & 120 & 273 & 15,00 & $14.000,00$ \\
\hline
\end{tabular}

\section{Valores considerados nos cálculos}

26 dias/mês -21 horas/dia $\rightarrow 546$ horas/mês.

Processo de injeção (fonte: indústria de transformação de termoplásticos)

- Custo de mão de obra: US\$4,40/hora;

- Custo de máquina injetora: US\$7,30/hora;

- Custo do acrílico para injeção: US\$2,60/kg;

- Efíciência do processo: $85 \%$;

- Molde para injeção com 4 cavidades.

Processo de Polimento de vidro (fonte: oficina de óptica do IFSC)

- Sistema semi-artesanal;

- Lotes de fabricação de 10 lentes;

- 4 horas para corte do vidro e gerar superficie;

- 8 horas para montagem do brocado;

- 8 horas para polimento por lado. 